AUTARQUIA ASSOCIADA À UNIVERSIDADE DE SÃO PAULO

\title{
PROPOSTA DE UMA METODOLOGIA PARA A DIVULGAÇÃO DA TECNOLOGIA NUCLEAR
}

Belinda Maria Lobo

Dissertação apresentada como parte dos
requisitos para obtenção do Grau de
Mestre em Ciências na Área
de Tecnologia Nuclear-Materiais

Orientador:

Prof. Dr. Afonso Rodrigues de Aquino

São Paulo 
INSTITUTO DE PESQUISAS ENERGÉTICAS E NUCLEARES

Autarquia Associada à Universidade de São Paulo

\section{PROPOSTA DE UMA METODOLOGIA PARA DIVULGAÇÃO DA TECNOLOGIA NUCLEAR}

Dissertação apresentada como parte dos requisitos para obtenção do Grau de Mestre em Ciências na Área de Tecnologia Nuclear - Materiais.

Orientador:

Prof. Dr. Afonso Rodrigues de Aquino 


\section{BELINDA MARIA LOBO}

\section{PROPOSTA DE UMA METODOLOGIA PARA DIVULGAÇÃO DA TECNOLOGIA NUCLEAR}

Dissertação apresentada ao Curso de Mestrado em Ciências na Área de Tecnologia Nuclear da Universidade de São Paulo como requisito parcial para obtenção do grau de Mestre em Ciências na Área de Tecnologia Nuclear. Área de concentração: Materiais.

Aprovada em 09 de novembro de 2017.

Presidente: Prof.Dr. Afonso Rodrigues de Aquino

Instituto de Pesquisas Energéticas e Nucleares

Universidade de São Paulo

Prof $^{\mathrm{a}} \mathrm{Dr}^{\mathrm{a}}$ Martha Marques Ferreira Vieira

Instituto de Pesquisas Energéticas e Nucleares

Universidade de São Paulo

Prof. Dr. Francisco Carlos Paletta

Escola de Comunicações e Artes

Universidade de São Paulo 


\section{DEDICATÓRIA}

A todos que acreditam no

AMOR e na COMPAIXÃO, CORAGEM e FÉ! 


\section{AGRADECIMENTOS}

Ao Prof. Dr. Afonso Rodrigues de Aquino que me inspirou da primeira aula até hoje, com orientações/comentários críticos pertinentes, dando até um norte para que eu voltasse para a minha vida produtiva, além do que, todos devem ter essa experiência, de escrever pelo menos uma ideia.

À Profa ${ }^{\text {. Dra }}$. Martha Marques Ferreira Vieira que esteve presente em todas as etapas do meu mestrado, avaliando, qualificando, suas aulas enriquecedoras e principalmente sugerindo de forma elegante itens a serem acrescentados ou excluídos.

Aos Profs. Drs. Roberto Vicente, Wanderlei Bergamaschi, Mitsuru H. Yanaze, Marcelo Guimarães e Francisco Carlos Paletta que enriqueceram esse trabalho com correções e comentários.

A todos do IPEN e da USP, professores doutores, doutorandos, mestrandos, funcionários das diversas unidades, da infraestrutura, da faxina, da biblioteca, as secretárias da pós-graduação em especial a Ana e Bruna pela competência, atenção e carinho em todos os momentos em que foram requisitados, realizando muito mais do que a sua função burocrática/funcional exige, quem dera se todos tivessem acesso a essa qualidade de ensino, o nosso país seria mais feliz.

Aos professores diretores Sandra R. G. Ortelan, Sirlene Manoel, Osmar Carvalho, coordenadoras Neide Kazan, Adriana A. Carvalho, a todos os professores e alunos que colaboraram para que este trabalho se efetivasse. Que eu tenha colaborado para despertar o interesse pela Tecnologia Nuclear.

Aos meus queridos e inestimáveis amigos, pessoas do bem: Sonia Guimarães, Daniela Gomes, Silvia Guimarães, Gabriella Bugni, Marta Blanco, Eliane Della Santa, Rosana Rocha, Sonia Ferreira, Neide Souza, colegas do Marchetti: Henrique, Eduardo, Patricia, Simone, Marilene, Silvia, Fabiana, Adilson, Flor, Anaenilda, lara, Sandra Maciel, Miriam Amaral, Ronaldo, Agnaldo, Paulo, 
Luis, Sandrinha, Cleusa, Sueli, Marcia, Aldo, Edson, do Zenaide: Hilda, Priscila, Silvia, Vera, Romilda, Sandra, Raquel, Jaciara, do Santa Tereza: Meire, Helena, da Yoga Arynanda em especial ao Prof. Ari, do Batuíra, do Rock e muitos outros não menos relevantes dos que foram citados aqui.

A todos os professores/educadores e aos meus ex-alunos maravilhosos.

À tecnologia nuclear, aos médicos, enfermeiras, auxiliares, nutricionistas, técnicas...que me ajudaram a ser mais feliz nesta vida.

À minha querida sogra Anisia Salgado, aos meus queridos cunhados Vera, Denise/família, Marcelo/Paçoca aos sobrinhos Renata, Nuno e aos meus netos tortos Enzo e Gael pelo carinho e orações.

A todos da minha maravilhosa família, não tenho como agradecer pelo amor que irradiam em todos os momentos da minha vida. Aos desbravadores e incentivadores pai Belarmino e minha mãe Socorrinha, à Adelaide que nos ensina todos os dias, às minhas adoráveis irmãs Sandra e gigante caçula Bernadete, meu querido cunhado Luís, meus sobrinhos Bruno, Josué e em especial Eduardo o único da família que leu/corrigiu/comentou, ao meu filho torto Fernando sempre me socorrendo na formatação e ao neto torto Felipe.

Aos meus queridos herdeiros maravilhosos Sophia e Hudson por deixar amá-los escancaradamente. Muito me orgulham pelas pessoas que são. Sophia pela sua fidelidade, inteligência, determinação e Hudson pela sua organização, inteligência e visualização do todo. Obrigada por terem me escolhido.

Ao Gê, companheiro, pela sua Fé, Sabedoria e Loucura, você me sustentou em todos os momentos da nossa vivência, obrigada pela sua musicalidade e a sua dança que me encantam.

Ao Caique, confidente, desarmado, fiel, por me ensinar o que é mais importante na minha vida, as "coisas" do coração... as emoções. Você me conhece melhor que eu mesma.

Deixo para vocês todo o meu desejo de que amem o que fazem e tenham compaixão por todos para alcançar mais rápido a felicidade (minha hipótese). Amo vocês. 


\section{RESUMO}

LOBO, Belinda M. Proposta de uma Metodologia para divulgação da Tecnologia Nuclear. 2017.107 p. Dissertação (Mestrado em Tecnologia Nuclear) Instituto de Pesquisas Energéticas e Nucleares - IPEN-CNEN/SP. São Paulo.

A maioria da população forma a sua opinião pelo senso comum, influenciada pelas informações divulgadas pela mídia, principalmente quando envolve acidentes. Normalmente, as notícias são veiculadas acentuando somente os seus aspectos negativos de forma dramática, o que em muito amplia o alcance espaço/temporal do impacto contrário de qualquer evento proveniente de ação antrópica, ou seja, não natural. Esse é o caso da Tecnologia Nuclear que, enquanto ciência e tecnologia, sofre as consequências decorrentes das duas bombas atômicas lançadas em 1945 sobre as cidades de Hiroshima e Nagasaki e dos acidentes com material radioativo. Até hoje, o público tem sérias restrições à sua utilização porque desconhece os benefícios que ela propicia para a sociedade, por terem a sua opinião formada pelo senso comum. Para o desenvolvimento da metodologia optou-se por trabalhar com grupos de professores como população amostral, haja vista que seus alunos são vetores para a disseminação do conhecimento adquirido em sala de aula, por serem profissionais críticos em relação às metodologias e aproximar a universidade aos profissionais de ensino. Este trabalho apresenta um roteiro de apresentação, como proposta para a divulgação da Tecnologia Nuclear para qualquer público, composta por cinco etapas: Questionário Inicial; Trecho de um Vídeo de uma reportagem do acidente com um aparelho de radioterapia; Palestra Elucidativa; Atividade Final e informações técnicas para Interação no Espaço da Tecnologia Nuclear.

Palavras-chave: Divulgação; Tecnologia Nuclear; Roteiro de Apresentação. 


\begin{abstract}
LOBO, Belinda M. Proposal for a Methodology for dissemination of the Nuclear Technology. 2017.107 p. Dissertação (Mestrado em Tecnologia Nuclear) Instituto de Pesquisas Energéticas e Nucleares - IPEN-CNEN/SP. São Paulo.
\end{abstract}

Most of the people form their opinion through common sense, influenced by the information disclosed by the media, especially when it involves accidents. Usually, the news is conveyed accentuating only its negative aspects in a dramatic way, which greatly enlarges the space / time reach of the contrary impact of any event coming from anthropic action, that is, unnatural. This is the case of Nuclear Technology, which as science and technology, suffers from the consequences of the two atomic bombs launched in 1945 on the cities of Hiroshima and Nagasaki and from accidents with radioactive material. To this day, people have serious restrictions on its uses, because they are not aware of its benefits to the society, due to their common sense forget opinion. For the development of the methodology it was decided to work with groups of teachers as sample population, since their students are vectors for the dissemination of the knowledge acquired in the classroom, also because they are critical professionals in relation to methodologies and to bringing the university closer to education professionals.

This work introduces a presentation screenplay as a proposal for the dissemination of Nuclear Technology to any public, composed of five stages: Initial Questionnaire; Video of news reporting the accident with a radiotherapy equipment; Elucidative Lecture; Final Activity and technic information to the Interaction in the Nuclear Technology Space.

Key words: Dissemination; Nuclear Technology; Presentation Screenplay. 


\section{SUMÁRIO}

Página

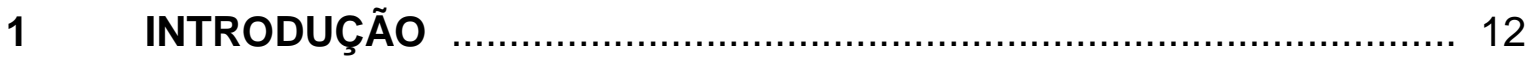

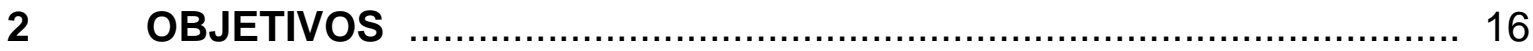

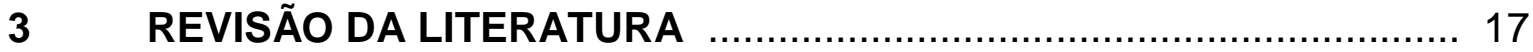

3.1 Divulgação Científica …………………….................................. 17

3.2 Estabelecer Comunicação ……………….................................... 18

4 METODOLOGIA PARA DESENVOLVIMENTO DA METODOLOGIA . 20

4.1 Público Amostral ................................................................... 20

4.2 Questionário Inicial ..................................................................... 21

4.3 Utilização de um vídeo ................................................................... 21

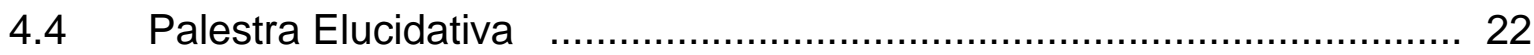

4.5 Questionário Final …………................................................... 23

4.6 Interação no Espaço da Tecnologia Nuclear ………………........... 23

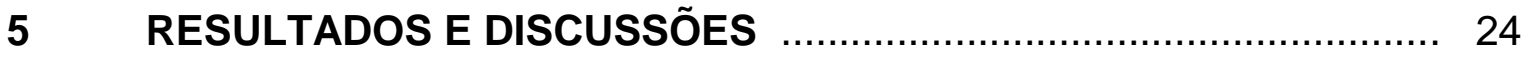

5.1 Questionário Inicial ............................................................... 24

$5.2 \quad$ Vídeo de uma Reportagem .............................................................. 31

$5.3 \quad$ Palestra Elucidativa ……………………............................... 32

5.4 Questionário Final ................................................................... 34

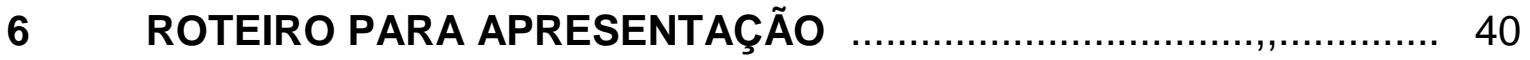

6.1 Primeira Etapa - Questionário Inicial.......................................... 40

6.2 Segunda Etapa - Vídeo de uma Reportagem ............................. 41

6.3 Terceira Etapa - Palestra Elucidativa ……….................................. 41

6.3.1 Discussão das causas do acidente com o aparelho de radioterapia em Goiás (1987) e a sua utilização ...................................................... 41

6.3.2 Radioatividade e Estrutura Nuclear ……....................................... 44

6.3.3 Decaimentos Nucleares Alfa, Beta negativo e Gama ……................ 47

6.3.4 Proteção Radiológica ................................................................. 50

6.3.5 Contaminação e Irradiação (material radioativo) ................................. 51

6.3.6 Raios-X (Energia Atômica) ……………………......................... 52

6.3.7 Radiofármacos (sua utilização e Meia-Vida) ......................................... 56

6.3.8 Plano de Segurança nas Termoelétrica tipo Pressurized Water Reator. 58 


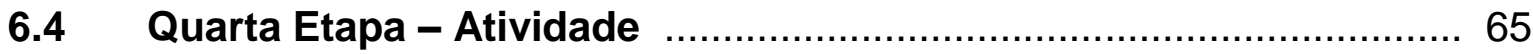

6.5 Quinta Etapa - Interação no Espaço da Tecnologia Nuclear .......... 68

6.5.1 Maquete do Vaso do Reator ................................................. 68

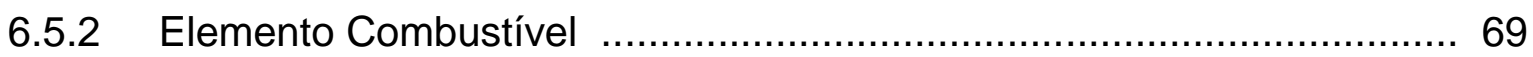

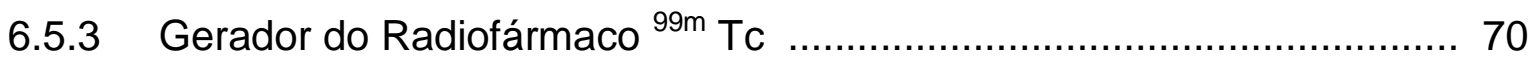

6.5.4 Aplicação da Irradiação ............................................................. 70

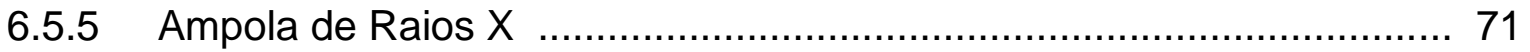

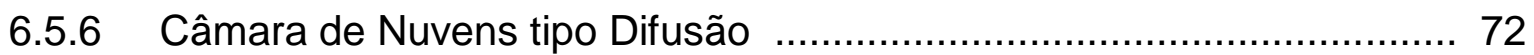

6.5.7 Detectores de Radiação ........................................................ 72

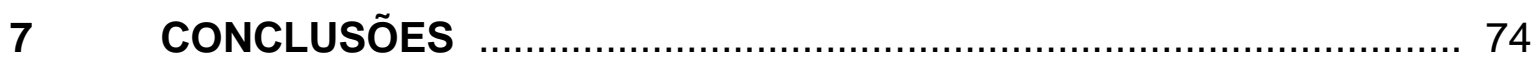

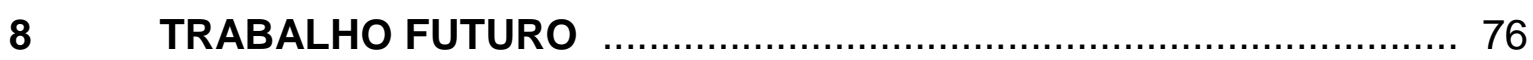

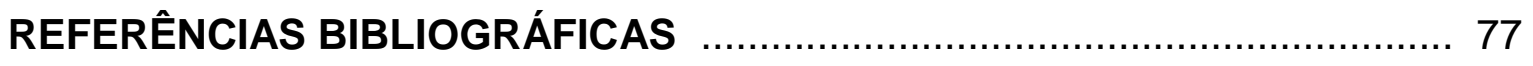

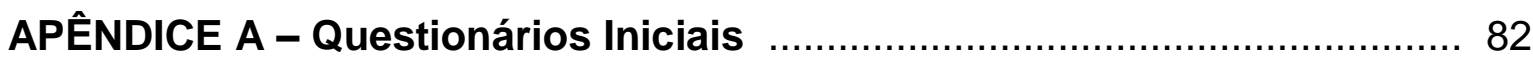

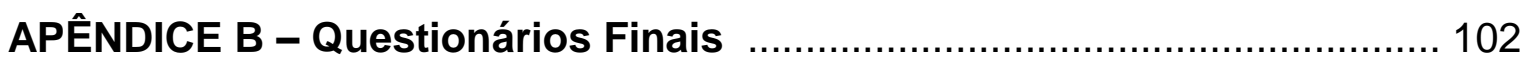

APÊNDICE C - Fotos de duas interações nas escolas ........................... 107 


\section{LISTA DE TABELAS}

\section{Página}

Tabela 1 - Respostas dos professores - Questionário Inicial - Pergunta 1 ..... 25

Tabela 2 - Respostas dos professores - Questionário Inicial - Pergunta 1 continuação 26

Tabela 3 - Respostas dos professores - Questionário Inicial - Pergunta 2 ..... 27

Tabela 4 - Respostas dos professores - Questionário Inicial - Pergunta $3 \quad$..... 29

Tabela 5 - Respostas dos professores - Questionário Inicial - Pergunta 4 ..... 30

Tabela 6 - Respostas dos professores - Questionário Inicial - Pergunta 5 ..... 31

Tabela 7 - Itens da Palestra Elucidativa: mantidos, retirados ou

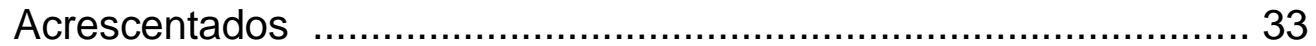

Tabela 8 - Respostas dos professores - Questionário Final - Pergunta 1 ...... 34

Tabela 9 - Respostas dos professores - Questionário Final - Pergunta 1

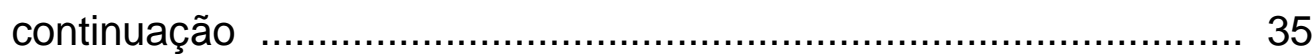

Tabela 10 - Respostas dos professores - Questionário Final - Pergunta 2 ........ 35

Tabela 11 - Respostas dos professores - Questionário Final - Pergunta 3 ...... 36

Tabela 12 - Respostas dos professores - Questionário Final - Pergunta 4 ...... 36

Tabela 13 - Respostas dos professores - Questionário Final - Pergunta 5 ...... 37

Tabela 14 - Tabela de geradores de radiofármacos. ${ }^{99 m}$ Tc possui a meia vida de $6 \mathrm{~h}$ e emite raios gama de baixa energia 


\section{LISTA DE FIGURAS}

\section{Página}

Figura 1 - Vídeo da Reportagem sobre o acidente com o aparelho de radioterapia em Goiás

Figura 2 - Quais foram as causas do acidente com o aparelho de Radioterapia?

Figura 3 - Aparelho de radioterapia possui material radioativo, Césio ou Cobalto

Figura 4 - Acelerador Linear (LINAC) não possui material radioativo, ao ser desligado não emite radiação 44

Figura 5 - Radioatividade - Elemento da natureza 45

Figura 6 - Tabela Periódica dos Elementos - Toda matéria é formada por um ou mais destes elementos

Figura 7A - Casal Curie - Precursores do estudo sobre radioatividade no simplório laboratório - Beneficiaram oito toneladas em um grama de sal de

Rádio 46

Figura 7B - Rocha contendo o minério na sua forma natural e os sais de Césio Beneficiado

Figura 8A - Exemplo do Berílio 47

Figura 8B - Urânio, quantidade de núcleons, prótons e nêutrons 47

Figura 9 - Decaimento Alfa $(\alpha)$. Plutônio ao emitir a partícula $\alpha$ se transforma em Urânio e este pode emitir outra partícula $\alpha$ se transformando em Tório

Figura 10 - Decaimento Beta Negativo $\left(\beta^{\circ}\right)$. Um nêutron se transforma em um próton mais uma partícula $\beta^{-}$e um antineutrino $(\bar{v})$, no núcleo do Césio e este tendo energia emite as partículas $\beta^{-}$e $\bar{v}$, transformandose no Bário instável que ao emitir raios gama $(\gamma)$ se torna estável 48

Figura 11 - Tipos de Radiação - Alfa, Beta e Gama 48

Figura 12 - Proteção Radiológica - Blindagem para radiação Alfa, Beta e Gama 
Figura 13A - Produtos comercializados nos anos $30 \mathrm{com}$ material radioativo. Creme para o rosto e relógios com marcadores

Figura 13B - Supositórios, sabonete para banhos e creme.. dental ................ 51

Figura 14A - Raios X: Irradia ou Contamina? .............................................. 52

Figura 14B - Banho de Sol: Irradia ou Contamina? .................................... 52

Figura 15 - Raios Gama: Irradia ou Contamina? …………………......... 53

Figura 16 - O aparelho de micro-ondas irradia ou contamina? ..................... 54

Figura 17 - Raios X - Irradiou? Contaminou? ………............................ 54

Figura 18 - Primeiro Raios X - Röentgen obtendo a primeira imagem

Radiográfica dos ossos da mão da sua esposa ........................ 55

Figura 19 - Os raios $X$ são produzidos dentro de um tubo de raios catódicos. Raios X - não é Energia Nuclear ………………................... 56

Figura 20 - Exame de Cintilografia Óssea: Irradia ou Contamina? .................. 57

Figura 21 - Cálculo da meia vida do Tecnécio metaestável ............................ 58

Figura 22 - Quem quer energia? Utilizar energia de forma sustentável .......... 59

Figura 23 - Qualquer forma para obter energia elétrica causa algum tipo de impacto Ambiental ............................................................ 60

Figura 24 - Matriz energética no Brasil no ano de 2015. As energias hidráulica, eólica, fotovoltaica e nuclear, representam 93\% na geração de energia elétrica

Figura 25 - Energia Nuclear - Energia Limpa! Na produção de energia elétrica não emite gases de efeito estufa

Figura 26 - Infraestrutura projetada para três usinas nucleares ..................... 62

Figura 27 - Fatores naturais protegem a Central Almirante Álvaro Alberto ...... 63

Figura 28 - Pressurized Water Reator (PWR) - Plano de Segurança .............. 64

Figura 29 - Gerenciamento de Resíduos Radioativos .................................... 65

Figura 30A - Maquete do Vaso do Reator Nuclear ....................................... 69

Figura 30B - Vareta do elemento combustível e amostras do ciclo do combustível

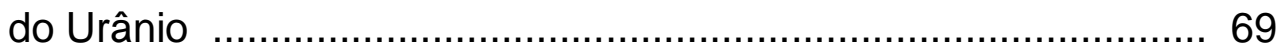

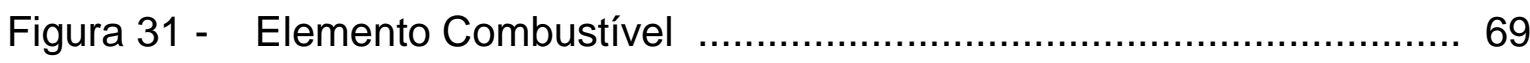

Figura 32 - Gerador do radiofármaco ${ }^{99 \mathrm{~m}} \mathrm{Tc}$, para diagnóstico de imagem ...... 70

Figura 33A - Produtos irradiados ............................................................. 71

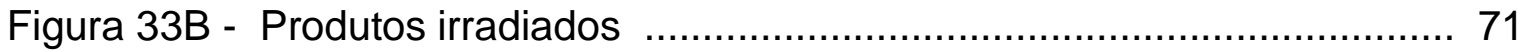


Figura 34A - Ampola de raios $X$

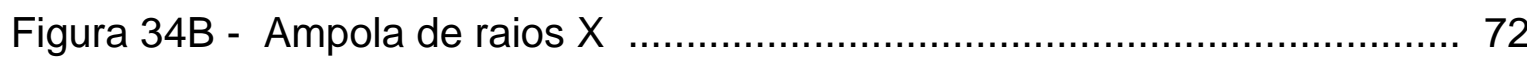

Figura 35A - Câmara de Nuvens tipo Difusão ...................................... 73

Figura 35B - Visualização dos rastros deixados por partículas energéticas de origem em um material radioativo no centro ........................ 73

Figura 36A - Detectores de radiação f................................................. 73

Figura 36B - Detector com interatividade ............................................. 73

Figura 37 - Apresentação para um grupo de professores e alunos da Escola Estadual Ermano Marchetti, quando se constatou a necessidade de haver uma atividade para melhorar o aprendizado

Figura 38 - Apresentação da versão final para professores doutorandos e mestrandos da Escola de Comunicação e Artes da Universidade de São Paulo 107

\section{LISTA DE SIGLAS}

CNAAA - Central Nuclear Almirante Álvaro Alberto

CNEN - Comissão Nacional de Energia Nuclear

ETN - Espaço da Tecnologia Nuclear

IPEN - Instituto de Pesquisas Energéticas e Nucleares

OCDE - Organização para a Cooperação e Desenvolvimento Econômico

PISA - Programa Internacional de Avaliação de Estudantes

PWR - Pressurized Water Reator

TN - Tecnologia Nuclear 


\section{INTRODUÇÃO}

Ao apresentar o tema Tecnologia Nuclear (TN) já se espera uma reação generalizada de medo, sentimento formado pela maneira pela qual o tema tem sido abordado pela mídia. Reportagens sensacionalistas (FISCHER, 2004) representam frequentemente o único modo de divulgação desse tema, especialmente quando ocorrem acidentes em usinas nucleares ou com material radioativo, muitas vezes sem buscar a opinião de pessoas especializadas na área nuclear e também quando se reforça o poder de destruição quando foi utilizado na segunda guerra mundial.

Utilizando-se a metáfora do mito da Caverna de Platão, pode-se discutir o medo sob a luz da filosofia. Com essa imagem, pode-se fazer o paralelo de uma sociedade que, durante longos anos, se encontra acorrentada dentro de uma caverna, com gerações de indivíduos cujo único contato com o mundo exterior é pelas sombras projetadas da realidade nas paredes da caverna. Como não se entende o que se vê ou escuta, interpreta-se que no mundo exterior existem monstros, e, por medo, preferem se manter numa zona de conforto, embora acorrentados dentro da caverna. Pode surgir, porém, um indivíduo que não se conforme com esta situação, motivando-se a mudanças e criando condições para se libertar das correntes a fim de buscar algo novo, fora da caverna. Assim, enfrentando suas crenças primordiais, depara-se inicialmente com a luminosidade do Sol, que pode cegá-lo pela condição de escuridão vivida até então, além da possibilidade de acovardar-se e voltar para o conforto da caverna. Contudo, ele pode se adaptar à nova condição e avaliar melhor as imagens do mundo real, colorido e diversificado, totalmente diferente das sombras desconexas que estava habituado a ver. Ao se adaptar à nova realidade vivenciada e gostar dela, sentindo o gosto da liberdade, o Homem sente compaixão por aqueles que ainda estão presos na caverna, retornando, assim, para divulgar o novo e promover a liberdade. A comunidade que ainda está presa dentro da caverna não aceita a nova versão e agride ou mesmo mata o indivíduo que está atrapalhando o conformismo e as crenças do grupo (CHAUí, 2003).

O medo relacionado à percepção de risco, segundo BOEMER (2011), é uma característica individual formada de acordo com as suas funções cognitivas, 
influenciada pela cultura e pelas crenças, gerando emoções e sentimentos que influenciam nas tomadas de decisões. Assim, o desconhecimento das causas do acidente como o de Fukushima em 2011 ou mesmo o de Goiânia em 1987 aumenta as percepções de risco, porque o indivíduo não tem como avaliar se o risco em utilizar a TN é aceitável pelo benefício que propicia à comunidade.

As palavras radioatividade ou energia nuclear remetem à ideia de energias prejudiciais à saúde. As pessoas em geral associam esses termos apenas a impactos ambientais antrópicos, não sabendo, por exemplo, que as emissões gases de efeito estufa totais da indústria nuclear do Reino Unido são quinhentas vezes menores que as do gás radônio emitido naturalmente de rochas que estão no solo e nas paredes dos edifícios (LOVELOCK, 2010).

A emoção do medo prepara o corpo para tipos de respostas diante de um perigo eminente, como o da imobilização, para que o indivíduo analise as possiblidades de ação, como agir, fugir ou se esconder. A atitude que promove mudanças ocorre quando há uma motivação emocional como de uma situação insustentável (GOLEMAN, 2011), no caso da metáfora do Mito da Caverna de Platão, pela falta de liberdade e pelo desconhecimento.

O que pode ocasionar o enfrentamento do medo seria a mudança nos valores adquiridos individualmente de acordo com a comunidade/realidade em que se vive, o fato de valorizar um bem maior como a liberdade, a obtenção de melhor condição de vida ou mesmo manter o conforto que já se tem, pode acarretar a mudança de opinião diante de um fato, após análise do risco/benefício (GAUDÊNCIO, 2007).

Em relação à epistemologia, o que motiva o saber, mesmo sendo formado pelo senso comum, é a curiosidade. Por isso, mesmo estando bem fundamentado nos conceitos que se quer apresentar, deve-se sempre respeitar o saber prévio do aprendiz estabelecendo na medida do possível o diálogo crítico, para que as partes se entendam promovendo o saber permanente (FREIRE, 2016).

Um desafio da educação moderna consiste em estabelecer e manter a comunicação entre os educadores e os educandos, porque a sociedade possui as mídias tecnológicas, principalmente a internet, com as quais, rapidamente obtêm-se qualquer tipo de informação de uma maneira atrativa, com conteúdos curtos, áudios instigantes e visuais coloridos e belos. Por isso, para aguçar a curiosidade e manter a atenção durante a apresentação para um público heterogêneo, a utilização de 
vários recursos audiovisuais faz-se interessante, como trechos de vídeos, slides com pouco texto, mas com figuras, animações e fotos, especialmente quando o tema é TN (SOARES, 2008), propiciando um ambiente de aprendizado e troca de conhecimento.

A seleção dos recursos auxiliares para transmissão do conhecimento deve ser bem criteriosa, pela necessidade de possuir uma linguagem acessível e de estar colimado com as obtenções de metas. Após a apresentação, deve-se elaborar uma atividade com o intuito de consolidar o aprendizado e avaliar o atingimento das metas (ALMEIDA, 2011).

Para estimular o aprendizado e a divulgação cientifica, deve-se recorrer a estratégias da comunicação promovendo também a produção de um trabalho específico (ZARUR, 2013), resultado de explicações claras e simples, de modo que o público se sinta num ambiente tranquilo para o aprendizado. Considera-se que o ensino está calcado em três pressupostos, a saber: 1) interpretação de texto; 2) raciocínio matemático e; 3) mente investigativa. Dentro dessa ideia, para verificar o aprendizado básico em diferentes países, a Organização para a Cooperação e Desenvolvimento Econômico (OCDE) lançou o Programa Internacional de Avaliação de Estudantes (PISA ${ }^{1}$ ) em 1997. O PISA avalia o que alunos de 15 anos, no final da educação obrigatória, adquiriram em relação a conhecimentos e habilidades essenciais para a completa participação na sociedade moderna. A avaliação trienal foca três áreas cognitivas - ciências, leitura e matemática (OCDE, 2016).

Pelo relatório pode-se constatar que o Brasil piorou seu posicionamento, caindo do $59^{\circ}$ lugar em 2012, $63^{\circ}$ lugar em 2015, em um universo de 72 países. A área de ciências teve a média de 405 pontos diminuída para 401 pontos. Curiosamente, nesse item de avaliação, a média de toda a Europa é de 493 pontos.

É fato consumado que a formação do senso comum é influenciada pela mídia (FISCHER, 2004). Isso exige especial atenção com o que está sendo veiculado, em termos de qualidade e de quantidade. Na área de jornalismo, em média, os temas abordados sobre ciência representam menos de $20 \%$ do total, incluindo as revistas e os jornais. A maioria das matérias sobre ciência trata de saúde e, além disso, a

\footnotetext{
${ }^{1}$ Fonte: https://g1.globo.com/educacao/noticia/brasil-cai-em-ranking-mundial-de-educacaoem-ciencias-leitura-e-matematica.ghtml
} 
área de exatas está incluída na área ambiental. O volume de publicações sobre a área das ciências exatas é insignificante no montante de temas jornalísticos. $\mathrm{O}$ Brasil acaba sendo uma referência quando o assunto é o analfabetismo científico e tecnológico. No Brasil, ciência não é cultura e o acesso a este tipo de conhecimento é uma questão de cidadania. As salas de aula de ciências são ilhas isoladas, uma civilização à parte com língua própria, e que não dialoga com o continente nem com as demais ilhas. Buscar no universo cognitivo do aluno informações para despertar o interesse, é a tarefa do professor ao trazer para a classe um tema como a TN. (AQUINO, 2005)

Tornar atraente um tema pouco trabalhado dentro das salas de aula já é um desafio. Em se tratando de um tema raramente abordado pela mídia em geral, e que quando é tratado apresenta um viés preconceituoso, a tarefa torna-se muito mais desafiadora. Para se vencer esse obstáculo, é necessária uma metodologia muito bem elaborada e que leve em conta todos os aspectos até aqui apresentados. 


\section{OBJETIVOS}

Este trabalho tem como objetivo geral apresentar uma Metodologia para Divulgação da Tecnologia Nuclear a ser aplicada para qualquer público.

Como objetivos específicos:

$\checkmark$ Desenvolver o estudo da metodologia em ambientes escolares, com grupos de professores como público amostral, adequando as estratégias com os dados obtidos;

$\checkmark$ Capacitar os professores com argumentos baseados em conceitos físicos e químicos, tornando-os disseminadores de opiniões na sala de aula e na comunidade;

$\checkmark$ Elaborar roteiro para interação no Espaço da Tecnologia Nuclear;

$\checkmark$ Divulgar alguns benefícios da utilização da Tecnologia Nuclear. 


\section{REVISÃO DA LITERATURA}

\subsection{Divulgação Científica}

O Homem, ao contemplar a natureza, estimulado pela curiosidade e pelo interesse, se abstrai para entender sua lógica, busca metáforas para promover visualizações, dando sentido ao que é conflituoso. O conhecimento assim adquirido é propagado ao longo de gerações, uma hipótese de estudiosos em arqueologia, acredita que nossos ancestrais tinham o hábito de sentar em torno do fogo onde além de assar a carne, se aquecerem e protegerem de animais ferozes (JOHNSON, 1982) era o momento em que havia a discussão e a divulgação dos conhecimentos adquiridos.

Os estudantes serão os provedores de saberes futuros, pesquisadores que contribuirão para a evolução da ciência, baseando-se no que é divulgado pela comunidade científica (GLEISER, 2010).

A motivação de se divulgar Ciência para a comunidade não científica apresenta duas vertentes: uma sustenta que a sociedade toma melhores decisões quando tem o conhecimento fundamentado; e a outra que afirma que isso estimularia estudantes a tornarem-se pesquisadores, dando continuidade à evolução do conhecimento. Como exemplo, cita-se o Japão: em uma pesquisa de opinião sobre o uso da energia nuclear para produzir energia elétrica, $40 \%$ dos japoneses continuam apoiando o seu uso (BOEMER, 2011) mesmo depois de serem vítimas das bombas nucleares na segunda guerra mundial.

Segundo $A Q U I N O^{2}$, a divulgação científica é a forma mais refinada para legitimar as atividades de pesquisa, porque grande parte das pesquisas é patrocinada com dinheiro público. Desta forma, a comunidade científica comunicaria para a sociedade o seu trabalho e suas pesquisas realizados.

Uma das dificuldades enfrentadas por pesquisadores é o fato de que nem sempre o público leigo entende o valor de seu trabalho. Conta-se que o grande matemático Laplace ao apresentar para Napoleão Bonaparte a primeira edição do

2 Contribuição do Prof.Dr. Afonso Rodrigues de Aquino. Fonte: Ciências e Sociedade: mediações jornalísticas. Organização Cremilda Medina. São Paulo: Estação Ciências: CCS/USP, 2005. 
seu trabalho, denominado Mécanique Céleste, o qual contém explicações sobre o movimento dos planetas, luas e cometas e outros fenômenos relacionados à gravidade, um verdadeiro aperfeiçoamento dos cálculos de Isaac Newton, o imperador teria the respondido que o trabalho foi árduo e longo, mas que ele não havia mencionado nada sobre o Criador (CAPRA, 1983).

A divulgação científica está associada às interações dentro do ambiente acadêmico por meio de publicações de dissertações e artigos, congressos ou mesmo nas aulas, restrito à área que se estuda, e regida por um rigor necessário para gerar credibilidade, promovendo a evolução do estudo. A difusão do conhecimento muitas vez se dá somente em um sentido pelo professor/cientista/pesquisador possuir um discurso autoritário e não admitir questionamentos ou discussões (FREIRE, 2016).

Segundo VIEIRA ${ }^{3}$, a ciência possui a metodologia programada, sistemática e metódica, possibilitando a qualquer um que tiver acesso àquela informação reproduzir o procedimento e obter o mesmo resultado. Todavia, a ciência pode partir do senso comum desperto por uma informação, pela curiosidade ou mesmo por uma realidade que se está vivendo.

Segundo FREIRE (2016) ensinar de forma crítica e apresentar o objeto ou o conhecimento exige ética, exige respeitar a autonomia do educando, sem ironizar, sem minimizar raciocínios divergentes, para que não se amesquinhe o direito nato de ser curioso e inquieto, qualidades que levam ao crescimento e ao aprendizado pelas diferenças dentro de um ambiente de respeito de todos.

\subsection{Estabelecer comunicação}

A rejeição da utilização da TN ocorre pela percepção de risco equivocado, pois as pessoas temem os impactos causados por um acidente com material radioativo. De acordo com os índices divulgados pelo PISA 2015, o Brasil caiu no ranking mundial de educação na área de ciências, o que nos remete à necessidade de melhorar a alfabetização científica, a começar pelos professores, capacitando-os para obter melhores resultados diante da atual realidade.

\footnotetext{
${ }^{3}$ Contribuição da Profa ${ }^{a}{ }^{a}$ Martha Marques Ferreira Vieira. Fonte: Ciências e Sociedade: mediações jornalísticas. Organização Cremilda Medina. São Paulo: Estação Ciências: CCS/USP, 2005.
} 


\begin{abstract}
Sobre mudanças, tenho visto e vivenciado que começam pelo racional. O número de informações a que temos acesso hoje em dia é imensamente maior que o das gerações que nos precederam, e a sua atualização se faz com uma velocidade que mal conseguimos acompanhar. Isso provoca um impacto no cérebro racional, e não ser diferente. Através da leitura de um livro, de uma conferência ou de um filme que nos impressiona, tomamos consciência da possibilidade de que a forma como vemos as coisas não é completa, nem mesmo a mais atual ou correta, e somos levados a pensar que é possível que outra visão do mundo, uma nova proposta, esteja mais próxima da verdade. Essa tomada de consciência é sempre desestabilizante, pois mostra que a zona de conforto em que nos colocamos pode ser falsa (GAUDÊNCIO, 2007).
\end{abstract}

Para que se obtenha êxito na divulgação para um público em geral, é necessário que aquele que deseja interagir com o público tenha um bom conhecimento do que deseja divulgar. Além disso, a curiosidade se desperta principalmente quando o indivíduo vive o fato e, por isso, quem deveria se comunicar com o público é aquele que vive a realidade da pesquisa ${ }^{4}$. É importante também ter bem definido os itens escolhidos, e utilizar para explicação uma linguagem acessível, com metas eficientes e executáveis, podendo, após a apresentação elaborar uma atividade para o público realizar com o intuito de consolidar o aprendizado (ALMEIDA, 2011).

Segundo RIBEIRO (2005), a metodologia de ensino baseada em problema é um método de instrução e aprendizagem colaborativo, construtivista e contextualizado para iniciar e focar a construção de conhecimentos para, a partir do problema, estabelecer comunicação entre as partes. Mesmo não utilizando a metodologia por inteira para uma pesquisa mais complexa, o foco inicial desta pesquisa é despertar o interesse pelo conhecimento da TN.

Sobre a contextualização, pode-se dizer que é uma ferramenta para estabelecer o diálogo a partir de reflexões sobre temas sociais e situações reais de forma dinamicamente articulada que possibilite a discussão (DOS SANTOS, 2008) como: a causa de um acidente já ocorrido, prevenções, avaliação do risco/benefício da utilização da TN.

\footnotetext{
${ }^{4}$ Fonte: Revista Ciência Hoje http://www.cienciahoje.org.br/noticia/v/ler/id/2551/n/divulgacao cientifica: para quem e por quem
} 


\section{METODOLOGIA PARA DESENVOLVIMENTO DA METODOLOGIA}

A importância desta pesquisa é a mesma buscar uma metodologia para a divulgação da TN que possa ser aplicada para qualquer público, mesmo sabendo da heterogeneidade do conhecimento, da cultura, crenças e objetivos peculiares de cada região de um estado ou mesmo país (BENEVIDES, 1996).

O intuito é idealizar uma proposta que seja reconhecida não como uma aula para um público específico da área nuclear, por isso a utilização ferramentas que se diferem, porém convergem para o aprendizado crítico, respeitando os diferentes níveis de capacidade de interpretação do conteúdo. O ensino não deveria ser considerado como transferência de conhecimento, acreditar que tudo possa ser assimilado de uma vez, sem respeitar a autonomia do público. O aprendizado é desperto pelo interesse ou mesmo pela curiosidade de entender algum tipo de manifestação que se interage (FREIRE, 2016).

\subsection{Público amostral}

Optou-se utilizar como público amostral professores do Ensino Fundamental, Médio e Universitário, por serem profissionais que expressam as suas ideias e anseios com facilidade, podendo assim aprimorar a metodologia, com os dados obtidos.

Foi decidido pela pesquisa qualitativa porque é uma fonte de informações obtidas no ambiente natural, investigando e interagindo na zona de conforto do público amostral, assim podem-se obter dados relevantes nos seus relatos (LÜDKE e ANDRÉ, 1986).

Visitaram-se escolas estaduais do município de São Paulo e apresentou-se para os diretores e coordenadores a proposta de divulgar a TN para os docentes. Em algumas escolas, os coordenadores não aceitaram que se fizesse a apresentação para todo o professorado, acreditando que o interesse seria somente para professores de ciências, física e química, conteúdo que faz parte da proposta curricular do estado de São Paulo (FINI, 2008), o que não conciliou com a ideia do estudo, de atingir um público variado composto também de leigos nesta área. 
Para o desenvolvimento do estudo, inicialmente utilizou-se das reuniões pedagógicas semanais - Aula de Trabalho Pedagógico Coletivo ${ }^{5}$, nas escolas estaduais Ermano Marchetti, Zenaide Vilalva de Araujo e Milton da Silva Rodrigues localizados em São Paulo, Capital. As reuniões eram constituídas por coordenadores e professores de Ensino Fundamental e Médio, de diversas áreas, tais como: Português, Matemática, História, Geografia, Biologia, Filosofia, Física, Química, Sociologia, Inglês e Educação Física.

Para obter dados de profissionais da área de comunicação e avaliar a metodologia, optou-se em apresentar a versão final para um público amostral de professores da Escola de Comunicação e Arte (ECA-USP).

\subsection{Questionário Inicial}

Para iniciar a interação pensou-se em utilizar de uma ferramenta que respeite o conhecimento prévio do público e que contextualize o que se tem o intuito de apresentar de forma democrática e crítica (DOS SANTOS, 2008). Utilizando-se de um questionário, ao ser respondido em pequenos grupos, todos podem manifestar as suas opiniões e ao mesmo tempo obter dados sobre:

$\checkmark$ Conhecimento prévio do público sobre radioatividade;

$\checkmark$ Aceitação da utilização da TN;

$\checkmark$ Conhecimento sobre o favorecimento da utilização da TN;

$\checkmark$ Conhecimento sobre o impacto ambiental;

$\checkmark$ Canal aberto para obter informações do que o público gostaria de conhecer sobre TN.

\subsection{Utilização de um Vídeo}

Para aguçar a curiosidade para o tema pensou-se na utilização de um trecho de um vídeo. Segundo MORÁN (1995), o vídeo está umbilicalmente ligado à televisão, a um contexto de lazer, o que para o aprendiz pode ser considerado como descanso. Neste contexto pode se explorar alguns sentidos como o visual e auditivo,

\footnotetext{
${ }^{5}$ Espaço/Tempo reservado para discussões relevantes, reflexões e estudo de projetos, nas escolas estaduais do estado de São Paulo.
} 
pelos seus efeitos coloridos e sonoros, levando o público a sentir-se no lugar dos personagens, do mundo ou mesmo de si próprio.

Desta maneira proporciona um ambiente de confiança (FREIRE, 2016), com significado numa linguagem acessível, sem cansar o público que não tem interesse em participar de uma dinâmica como se fosse mais uma aula expositiva, onde o discente senta no seu lugar e recebe informações, sem poder expressar os seus pensamentos e opiniões. É necessário apresentar itens que as pessoas gostariam de saber e a duração da interação ideal, suficiente para não cansá-lo.

Utilizando a internet para a busca do vídeo, se depara com inúmeras reportagens sobre o acidente na usina nuclear de Chernobyl, sobre as bombas utilizadas na segunda guerra mundial, vídeos elaborados por estudantes, sobre o projeto do submarino nuclear brasileiro, reportagens sobre o programa brasileiro do enriquecimento do urânio, o vídeo do IPEN- Aplicações da Tecnologia Nuclear. Observou-se que o maior número de visualizações era para as reportagens relacionadas aos acidentes ocorridos com material radioativo, levando a acreditar que para aguçar a curiosidade deveria se escolher um vídeo que obteve grande audiência.

\subsection{Palestra Elucidativa}

Sobre selecionar os itens a serem apresentados numa palestra, deve se iniciar com o assunto abordado no vídeo, para sanar a curiosidade estimulada por ele, sendo o elo que irá ligar o senso comum formada por alguma reportagem divulgada pela mídia em larga escala, para os conceitos fundamentados da universidade.

É necessário ter bem definido os itens escolhidos e utilizar para explicação uma linguagem acessível, com metas eficientes e executáveis, podendo, após a apresentação elaborar uma atividade para que o público possa realizar com o intuito de consolidar o aprendizado (ALMEIDA, 2011).

Um desafio da educação também é em estabelecer e manter a comunicação entre os educadores e os educandos porque atualmente a maioria está acostumada às mídias tecnológicas, principalmente à internet, que dão qualquer tipo de informação com acesso rápido, atrativo tanto em relação aos áudios como nos visuais coloridos e belos. Aguçar a curiosidade e manter a atenção durante a 
palestra propiciando um ambiente de aprendizado e troca de conhecimento se dá utilizando vários recursos, como trechos de vídeos, slides com pouco texto, com figuras, animações e fotos (SOARES, 2008).

$O$ intuito é que a cada apresentação feita se analise os dados obtidos e com eles se adapte melhor ao que o público almeja aprender. Os itens planejados inicialmente foram:

$\checkmark$ Discussão do assunto abordado no vídeo;

$\checkmark$ Diferença entre Energia Atômica e Nuclear;

$\checkmark$ Fissão Nuclear e reação em cadeia;

$\checkmark$ Raios X - Radiação de freamento e espectro de raios X característico;

$\checkmark$ Diferença entre Irradiar e Contaminar;

$\checkmark$ Promover a importância do Centro de Radiofarmácia-IPEN;

$\checkmark$ Explicar sobre o Efeito Estufa e Aquecimento Global;

$\checkmark$ Associar a produção de Energia Elétrica com a TN à energia limpa.

\subsection{Questionário Final}

Após a palestra, pensou-se em avaliar a metodologia aplicando o mesmo questionário utilizado antes da palestra podendo assim comparar as respostas iniciais e finais das mesmas perguntas.

Para estimular o aprendizado e a divulgação cientifica pode-se utilizar um momento para produção de um trabalho (ZARUR, 2013) resultado de explicações claras e simples ou mesmo uma atividade para reforçar o conteúdo apresentado.

\subsection{Interação no Espaço da Tecnologia Nuclear}

O público que for recebido no local de exposição, identificado como Espaço da Tecnologia Nuclear, localizado no Instituto de Pesquisas Energéticas e Nucleares IPEN, que fica no campus da Universidade de São Paulo - São Paulo, Capital, onde são apresentadas algumas contribuições da TN para a medicina, a indústria, a pesquisa e a geração de energia elétrica, deverá receber um roteiro com informações úteis que satisfaça à sua curiosidade e reforce o seu aprendizado. Com essa atitude, é esperada uma melhor avaliação do risco/benefício da utilização da TN. 


\section{RESULTADOS E DISCUSSÕES}

\subsection{Questionário Inicial}

O Questionário inicial foi aplicado para todos os grupos de professores com o intuito de contextualizar, promover a oportunidade para que todos possam se expressar e obter opiniões espontâneas sobre Energia Nuclear (EN).

Com a primeira questão analisou-se o conhecimento prévio; com a segunda questão, contabilizou-se a aceitação da utilização da EN, levando o indivíduo a se posicionar como um ativista governamental. Na terceira questão, ao mencionar tecnologia de ponta, imediatamente vêm à mente os países do Primeiro Mundo como Japão, Estados Unidos, França, Alemanha. Ao questionar se o Brasil tem se favorecido da evolução da tecnologia nuclear, o indivíduo é convidado a analisar a existência de tal possibilidade. Na quarta questão, o foco foi o da preocupação com um mundo que deveria ser ecologicamente correto, o impacto ambiental causado por qualquer atividade antropogênica. Devido à mídia sensacionalista a percepção de risco ambiental da utilização da energia nuclear é muito alta (BOEMER, 2011), mesmo desconhecendo os seus benefícios. Na quinta e última questão, deixou-se um canal aberto de comunicação, para os colaboradores apresentarem dúvidas ou mesmo curiosidades sobre o tema, contribuições que melhoraram a metodologia.

\section{O que é Energia Nuclear? Onde pode ser utilizada?}

2. SE você fizesse parte da "Equipe Científica Intelectual” do governo, seria a favor da utilização da Energia Nuclear? Em qual área? Justifique a sua resposta.

3. O Brasil tem se beneficiado da Evolução da Tecnologia Nuclear? Como?

4. Você conhece algum impacto ambiental causado pela utilização da Tecnologia Nuclear? Por favor, cite exemplo (s).

5. Sobre o assunto de Energia Nuclear, você tem dúvidas ou interesse em saber sobre qual item? 
Esta etapa foi relevante, porque foi possível analisar as características do público utilizando as respostas para acrescentar ou retirar assuntos da palestra elucidativa, havendo assim o compromisso de se adequar ao público. Obteve-se a colaboração de 51 professores, cujas respostas sintetizadas estão apresentadas a seguir nas tabelas $1,2,3,4,5$ e 6 . Os questionários preenchidos estão no APÊNDICE A.

A tabela 1 refere-se às respostas obtidas com a primeira questão: "O que é Energia Nuclear?" Pode-se constatar que 47\% dos professores tem noção do que seja EN, porém, percebe-se a necessidade de explicar sobre a estrutura da matéria, forças nucleares e decaimentos nucleares.

Tabela 1 - Respostas dos professores do Questionário Inicial - Pergunta 1. Número de Respostas da pergunta 1. 0 que é Energia Nuclear? professores

$\begin{array}{cl}\text { 47\% - 24 } & \text { É a energia liberada em processos de transformação de núcleos } \\ & \text { atômicos. } \\ 17 \% \text { - } 9 & \text { É uma energia que é "promovida através" de materiais } \\ & \text { radioativos que se transformam. } \\ 7 \%-4 & \text { Energia produzida pelo homem utilizando substâncias químicas. } \\ 3 \%-2 & \text { É a energia gerada pela movimentação/choque dos átomos. } \\ 2 & \text { Forma de "geração" de energia. } \\ 2 & \text { É uma forma de produção de energia com fontes de metais } \\ 2 & \text { pesados. } \\ 2 & \text { É a energia gerada através dos radioisótopos. } \\ 2 & \text { É o enriquecimento urânio } \\ 1 & \text { Do átomo nasce matéria, prótons, elétrons e nêutrons. } \\ 1 & \text { É a energia referente ao núcleo de um átomo. Pode ocorrer sua } \\ & \text { fusão, ou fissão dependendo da situação. }\end{array}$

Fonte: Elaborada pela autora.

Na tabela 2 é a continuação da questão 1: "Onde pode ser utilizada?" Percebe-se que a maioria, 64\% dos professores, tem conhecimento da utilização da TN para a produção da Energia Elétrica; 47\% na medicina; inevitavelmente para 
equipamentos bélicos, bombas nucleares. Observou-se também que associaram EN com energia atômica para a produção de raios $X$ (exames de imagens), realização de tomografias e a sua utilização ao acessar energia elétrica. Para a palestra, optou-se por levantar discussões sobre a produção da Energia Elétrica, aplicação na Medicina Nuclear e evitar a discussão sobre a sua utilização nas questões bélicas, o que é irrelevante para a divulgação da TN.

Tabela 2 - Respostas dos professores do Questionário Inicial - Pergunta 1 continuação. (A porcentagem foi calculada em relação ao total de respostas).

\section{Número de Respostas da pergunta: Onde pode ser utilizada? professores}

$\begin{array}{ll}\text { 64\% - 33 } & \text { Usinas Nucleares; para geração de energia elétrica; fonte de } \\ & \text { energia elétrica; energia industrial, doméstica; fonte de energia; } \\ & \text { Angra I e II } \\ 47 \% \text { - } 24 & \text { Equipamentos médicos; Medicina Nuclear; aparelhos de } \\ & \text { exames de imagem ou radioterapia; tratamentos médicos; } \\ & \text { tratamento de doenças; em hospitais; realização de } \\ & \text { tomografias } \\ 29 \%-15 & \text { Equipamentos bélicos; bomba atômica; para matar } \\ 14 \%-7 & \text { Alimentos; "desinfecção" de alimentos } \\ 14 \%-7 & \text { Não citaram utilidades } \\ 8 \%-4 & \text { Para qualquer equipamento ou tecnologia que requer energia; } \\ 6 \%-3 & \text { outras tecnologias } \\ 4 \%-2 & \text { Em tudo } \\ 2 \%-1 & \text { Pudo que necessita de eletricidade }\end{array}$

Fonte: Elaborada pela autora.

Na tabela 3 apresenta-se as respostas sintetizadas da questão 2: "SE você fizesse parte da Equipe Científica Intelectual do governo, seria a favor da utilização da energia nuclear? Em qual área? Justifique a sua resposta. " 
Tabela 3 - Respostas dos professores do Questionário Inicial - Pergunta 2.

(O número de professores não totaliza o número de justificativas porque citaram mais de um item nas suas respostas.)

\begin{tabular}{|c|c|}
\hline $\begin{array}{l}\text { Número de } \\
\text { professores }\end{array}$ & $\begin{array}{l}\text { Respostas da pergunta: } 2 \text {. SE você fizesse parte da "Equipe } \\
\text { Científica Intelectual" do governo, seria a favor da utilização da } \\
\text { energia nuclear? Em qual área? Justifique a sua resposta. }\end{array}$ \\
\hline \multicolumn{2}{|l|}{$51 \%-26-$ SIM } \\
\hline 17 & $\begin{array}{l}\text { Na área médica para a utilização de equipamentos para radioterapia e } \\
\text { quimioterapia; Medicina. São áreas deficientes atualmente no Brasil. }\end{array}$ \\
\hline 5 & $\begin{array}{l}\text { Produção de energia industrial. Para auxiliar na produção de energia } \\
\text { sendo que haja fiscalização rígida. }\end{array}$ \\
\hline 4 & Energia elétrica, por ser a mais limpa fonte de gerar energia. \\
\hline 2 & Para reserva e deve ser utilizada em épocas de contingenciamento. \\
\hline \multicolumn{2}{|l|}{$29 \%$ - 15 - NÃO } \\
\hline 3 & Não é uma energia "limpa", pode contaminar o meio ambiente. \\
\hline 3 & O Brasil não tem capacidade para administrar um acidente nuclear. \\
\hline 2 & $\begin{array}{l}\text { O Brasil tem muitas várias formas de utilização e energias. } \\
\text { (Eólica/Solar). }\end{array}$ \\
\hline 2 & Radioativa e lixo tóxico e provoca um impacto ambiental. \\
\hline 2 & $\begin{array}{l}\text { Por causa dos acidentes em geral; somente para fins } \\
\text { terapêuticos }\end{array}$ \\
\hline 2 & Porque atualmente o ser humano não está preparado \\
\hline $20 \%-10-N A ̃ O$ & OPINARAM \\
\hline 3 & Estamos abertos ao debate. \\
\hline 3 & Substituição à energia elétrica. \\
\hline 2 & $\begin{array}{l}\text { Dependeria de estudos e informações mais amplas a respeito do } \\
\text { assunto, para determinar a viabilidade desse tipo de energia em nosso } \\
\text { país. }\end{array}$ \\
\hline 1 & Como forma excepcional, num caso de falta energia renovável. \\
\hline 1 & $\begin{array}{l}\text { Acho delicado "mexer" com um assunto tão delicado, ainda mais com } \\
\text { o nosso governo. Independente do grau de periculosidade, da linha de } \\
\text { estudo; dependendo de sua aplicação e todo o caminho para alcançar } \\
\text { esta aplicação deve-se ter muito critério e controle. }\end{array}$ \\
\hline
\end{tabular}

Fonte: Elaborada pela autora. 
Observou-se que a maioria $51 \%$ dos professores, 26 dos 51, é a favor da utilização da EN na área médica e dezessete professores acreditam que a quimioterapia utiliza TN; 29\%, 15 dos 51, se posicionaram contra a utilização da TN sendo as suas justificativas relacionadas as questões ambientais, de forma equivocada acreditam que não seja energia limpa, que em um acidente com material radioativo ou nas usinas nucleares causará grandes impactos ambientais, pelo Brasil não ter competência para gerenciar e que existem outras formas de obter energia elétrica. Quase 20\%, 10 dos 51, não se posicionaram, porém, estão abertos ao debate, como 3 professores justificaram. Com esses dados acrescentouse sobre o plano de segurança nas termoelétricas do tipo Pressurized Water Reator (PWR).

A tabela 4 refere-se às respostas da questão 3: " 0 Brasil tem se beneficiado da evolução da tecnologia nuclear? Como? " Pode-se constatar que $43 \%$, ou seja, 22 dos 51 acreditam que o Brasil tem se beneficiado com a evolução da TN, principalmente na área de produção de energia elétrica. Ao somar $25 \%$ dos que não sabem, mais $21 \%$ dos que não opinaram, mais $10 \%$ que não acreditam que o Brasil tem se beneficiado com a utilização, totaliza $56 \%$, a maioria desconhece ou acredita que a EN contribui muito pouco. Com a análise desses dados acrescentou-se na palestra como é a produção da energia elétrica no Central Nuclear Almirante Álvaro Alberto. 
Tabela 4 - Respostas dos professores do Questionário Inicial - Pergunta 3

\begin{tabular}{|c|c|}
\hline $\begin{array}{l}\text { Número de } \\
\text { professores }\end{array}$ & $\begin{array}{l}\text { Respostas da pergunta 3. O Brasil tem se beneficiado da } \\
\text { evolução da tecnologia nuclear? Como? }\end{array}$ \\
\hline $22-43 \%$ & SIM \\
\hline 10 & Angra I e Angra II \\
\hline 3 & Controle biológico \\
\hline 3 & $\begin{array}{l}\text { Com os avanços tecnológicos em diversas áreas. Porém, ainda } \\
\text { o maior acesso é para quem possui mais capital. }\end{array}$ \\
\hline 2 & Medicina \\
\hline 2 & Não citaram como \\
\hline 2 & $\begin{array}{l}\text { Pois a pesquisa tem sido muito rigorosa e tem o } \\
\text { acompanhamento de autoridades da área de outros países. }\end{array}$ \\
\hline $13-25 \%$ & NÃO SABEM \\
\hline 5 & Não sei. Muito pouco. Pouco. \\
\hline 4 & Não sabemos. \\
\hline 2 & $\begin{array}{l}\text { Desconhecemos totalmente os benefícios dessa Tecnologia na } \\
\text { área de abastecimento de energia. }\end{array}$ \\
\hline 2 & Não sei dizer. Penso que é subaproveitada. \\
\hline $11-21 \%$ & NÃO OPINARAM \\
\hline 4 & $\begin{array}{l}\text { Pela pequena utilização para a energia elétrica. Enriquecimento } \\
\text { de Urânio. Existe apenas uma usina. }\end{array}$ \\
\hline 3 & $\begin{array}{l}\text { Angra I e Angra II (embora Alemanha não tenha parado os } \\
\text { estudos sobre assunto). }\end{array}$ \\
\hline 3 & Acreditamos que ela é utilizada pela medicina. \\
\hline 1 & . Excepcionalmente, para a falta de energia elétrica. \\
\hline $5-10 \%$ & NÃO \\
\hline 2 & A energia nuclear de Angra se utiliza pouco a energia \\
\hline 2 & - \\
\hline 1 & Por ser uma energia que pode causar danos ao meio ambiente. \\
\hline
\end{tabular}

Fonte: Elaborada pela autora.. 
A tabela 5 apresenta as respostas da questão 4: " Vocês conhecem algum Impacto Ambiental causado pela utilização da Tecnologia Nuclear? Cite exemplos. "Pode se constatar que todos citaram acidentes que ocorreram em usinas nucleares ou com material radioativo e não impactos ambientais causados na extração do minério, no comissionamento e descomissionamento de instalações que realização operações com a TN. Observa-se que a maioria citou exemplos mundiais e como 20 professores citaram o caso do acidente com material radioativo em Goiânia, reforçou a escolha de utilizar um trecho de um vídeo com a reportagem do acidente com o aparelho de radioterapia, como instrumento de contextualização para estimular o interesse em estudar TN.

Tabela 5 - Respostas dos professores do Questionário Inicial - Pergunta 4.

Número de Respostas da pergunta 4. Vocês conhecem algum Impacto

professores Ambiental causado pela utilização da Tecnologia Nuclear? Cite Exemplos.

\begin{tabular}{cl}
\hline 24 & Vazamentos de Usinas, Equipamentos Nucleares, Chernobyl, \\
& Acidentes Nucleares. \\
20 & Goiânia, episódio dos equipamentos com Césio no Brasil \\
17 & Fukushima \\
7 & Hiroshima e Nagasaki \\
5 & Em caso de acidentes: doenças, fauna \\
4 & União Soviética - Japão - Ucrânia, Alemanha \\
4 & Acidentes Nucleares ou com Equipamentos \\
4 & Nãamento em Angra dos Reis \\
\hline
\end{tabular}

Fonte: Elaborada pela autora.

A tabela 6, respostas da questão 5: "Sobre o assunto energia nuclear, você tem dúvidas ou interesse em saber sobre qual item?" Com os dados apresentados, enfatiza-se que todos têm interesse em saber mais sobre EN, e como 24 professores citaram, com uma linguagem simplificada. Com esta contribuição, acrescentou-se o item sobre meia-vida física de um nuclídeo radioativo, porém, mesmo 8 professores querendo saber como é confeccionada uma bomba nuclear, não se acrescentou este item na palestra porque não se tem o intuito de divulgar questões bélicas. 
Tabela 6 - Respostas dos professores do Questionário Inicial - Pergunta 5.

Número de Respostas da pergunta 5. Sobre o assunto energia nuclear, professores você tem dúvidas ou interesse em saber sobre qual item?

24 Todos; saber e rever informações; Melhor comunicação... linguagem simplificada; malefícios e benefícios da energia nuclear Impactos Ambientais pelo uso da energia nuclear; lixo nuclear; prevenção de acidentes; segurança.

9 Acúmulo dessa energia no organismo; na medicina; Tratamentos

8 Básico; Área Física; como é feito a bomba atômica.

Fonte: Elaborada pela autora.

\subsection{Vídeo de uma Reportagem}

$\mathrm{Na}$ internet há vários vídeos que abordam o tema da EN, optou-se pelo vídeo Linha Direta Justiça - Césio137 (CÉSIO 137, 2007), por ser uma questão brasileira e a escolha foi favorecida quando se observou que o assunto ainda estava na memória de alguns professores, conforme constatado no questionário inicial, figura 1.

Figura 1. Vídeo da Reportagem sobre o acidente com o aparelho de radioterapia em Goiás.

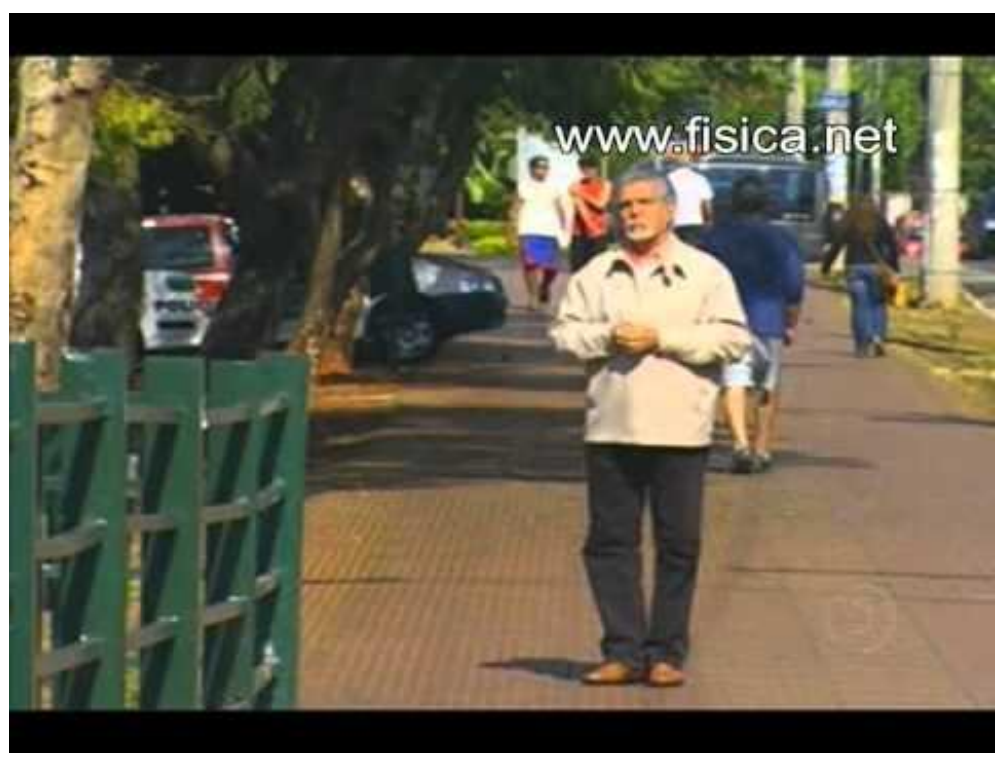

Fonte: https://www.youtube.com/watch?v=Zyk42C8eKrs 
O vídeo de uma reportagem foi uma etapa importante porque manteve o público, inicialmente, na zona de conforto para abrir um canal de comunicação (ZARUR, 2013) utilizando inicialmente a linguagem midiática (FISCHER,2004), para depois utilizar a linguagem conceitual e formal da ciência.

Importante enfatizar que somente sete minutos do vídeo, talvez até menos, foram necessários para despertar o interesse, pois acontecimentos no mundo são transformados em reportagens sensacionalistas, tornando-os trágicos, e exibidos pela mídia para aumentar a audiência (FISCHER, 2004), que causa muito medo e estabelece na memória do público a mesma opinião do programa assistido, normalmente uma ideia negativa. Quando se deseja que uma pessoa mude de opinião, no caso favorável a utilização da TEN, é necessário despertar o interesse para o tema, discutindo o medo (GAUDÊNCIO, 2007), neste caso, o da utilização de material radioativo.

O trecho da reportagem exibe a simulação do acidente com material radioativo, Césio 137, que estava em um aparelho de radioterapia, abandonado pelo Instituto Goiano de Radioterapia, quando se transferiu para outra localidade. Na cidade de Goiânia,em setembro de 1987, catadores de material reciclável entraram na clínica abandonada, retiraram o aparelho de radioterapia e venderam para o dono de um ferro velho que ao desmembrar o aparelho, quebrou a blindagem que protegia o material radioativo, iniciando a contaminação do local e de algumas pessoas (OKUNO, 2016). A reportagem também contém depoimentos de pessoas, tais como: um juiz, do irmão do dono do ferro-velho, uma atriz, de um artista plástico, que sensibilizam o público. Também há o depoimento de um físico e de um representante da Comissão Nacional de Energia Nuclear (CNEN), porém se explica pouco sobre energia nuclear e o porquê das medidas tomadas em Goiânia para amenizar os impactos causados pela violação da fonte radioativa.

\subsection{Palestra Elucidativa}

As palestras foram iniciadas com explicações sobre os itens abordados no vídeo, seguida da apresentação de conteúdos fundamentais e benefícios da EN. Para isso, concomitantemente com o conteúdo de física e química, foram utilizadas muitas fotos, ilustrações e figuras pitorescas, tornando o conteúdo acessível e 
compreensível em um ambiente confiável por promover sempre a interação que propicie o interesse para o aprendizado (FREIRE,2016).

Ao longo do estudo, muitos itens foram retirados, como: o quadro de modelo padrão de partículas elementares; vídeo da reação em cadeia; explicação sobre o efeito estufa, gases de efeito estufa e aquecimento global. Os temas centrais focaram-se então a utilização da TN na medicina (radiofármacos) e a produção de energia elétrica como apresentado na tabela 7.

Tabela 7 - Itens da Palestra Elucidativa: mantidos, retirados ou acrescentados.

\begin{tabular}{lll}
\hline \multicolumn{1}{c}{ Mantido } & \multicolumn{1}{c}{ Retirado } & \multicolumn{1}{c}{ Acrescentado } \\
\hline - Causas do acidente & - Centro de Radiofarmácia & - Radioatividade e \\
com aparelho de & & Estrutura Nuclear \\
radioterapia & & \\
- Diferença entre Irradiar & - Efeito Estufa e gases de & - Decaimentos $\alpha, \beta$ e $\gamma$ \\
e Contaminar & efeito estufa & \\
- Proteção Radiológica & - Aquecimento Global & - Raios - X \\
& - Diferença entre Energia & - Radiofármacos (meia- \\
& Atômica e Nuclear & Vida) \\
& - Fissão Nuclear - Reação & - Plano de segurança \\
& em cadeia & nas Termoelétricas Tipo \\
& & PWR \\
\end{tabular}

Fonte: Elaborada pela autora.

Desta forma os itens estabelecidos para esta etapa são:

$\checkmark$ Discussão das causas do acidente com o aparelho de radioterapia em Goiás (1987) e a sua utilização;

$\checkmark$ Radioatividade e Estrutura Nuclear;

$\checkmark$ Decaimentos Nucleares: Alfa, Beta negativo e Gama;

$\checkmark$ Proteção Radiológica;

$\checkmark$ Contaminação e Irradiação (material radioativo);

$\checkmark$ Raios-X (Energia Atômica);

$\checkmark$ Radiofármacos (sua utilização e Meia-Vida);

$\checkmark$ Plano de Segurança nas Termoelétricas tipo Pressurized Water Reator. 


\subsection{Questionário Final}

Depois da palestra, com os primeiros grupos, o questionário final era 0 mesmo que o inicial, porque em princípio queria se comparar as respostas iniciais com as finais para avaliar a metodologia. As tabelas 8, 9, 10, 11, 12 e 13 são referentes as respostas de 12 professores colaboradores, que devolveram os questionários finais, APÊNDICE B, os quais foram úteis para modificar os assuntos abordados na palestra, mesmo que numa quantidade reduzida, foi importante para análise da necessidade deste tipo de questionário, com as mesmas questões do questionário inicial.

Com as respostas da tabela 9 observa-se que depois da palestra, o entendimento sobre a EN ainda era muito limitado; dois professores associaram ao movimento de fricção (talvez confundiram com fissão), constatou a necessidade de uma outra forma de revisar o conteúdo.

Tabela 8- Respostas dos Professores - Questionário Final - Pergunta 1.

\begin{tabular}{cl}
$\begin{array}{c}\text { Número de } \\
\text { professores }\end{array}$ & Respostas da pergunta 1. O que é Energia Nuclear? \\
\hline 9 & Energia proveniente do núcleo do átomo. \\
2 & $\begin{array}{l}\text { É energia movida à fricção de urânio e também chamada } \\
\text { atômica. }\end{array}$ \\
1 & A energia nuclear pode ser obtida através do átomo.
\end{tabular}

Fonte: Elaborada pela autora.

Na tabela 9, observam-se que todas as respostas estão corretas, além desta análise, todos os professores mencionaram a utilização para a geração elétrica, quase todos para área médica, esterilização de alimentos e chama a atenção que mesmo não tendo discutido em momento algum sobre a questão bélica, ela reaparece nas respostas de seis professores. 
Tabela 9 - Respostas dos professores - Questionário Final - Pergunta 1 continuação.

Número de Respostas da pergunta: Onde pode ser utilizada?

professores

12

Geração de energia (elétrica); Reatores

10 Tratamento de doenças; Diagnósticos; Medicina

$6 \quad$ Setor Militar; Produção de bombas

3 Esterilização de alimentos

Fonte: Elaborada pela autora.

Nas tabelas 10 e 11, observa-se que a maioria dos professores é a favor da utilização da EN, na medicina e na produção da energia elétrica, porém pode-se constatar que a desconfiança ainda perdura, mesmo que na minoria.

Tabela 10 - Respostas dos professores - Questionário Final - Pergunta 2.

\begin{tabular}{cl}
\hline $\begin{array}{c}\text { Número de } \\
\text { professores }\end{array}$ & $\begin{array}{l}\text { Respostas da pergunta: 2. SE você fizesse parte da } \\
\text { "Equipe Científica Intelectual" do governo, seria a favor da } \\
\text { utilização da energia nuclear? Em qual área? Justifique a } \\
\text { sua resposta. }\end{array}$ \\
\hline $\mathbf{7 - S I M}$ & Na medicina; \\
7 & Produção de energia \\
6 & OPINARAM \\
$\mathbf{5 - N A ̃ O}$ & Necessitaríamos de maiores dados estatísticos para \\
3 & $\begin{array}{l}\text { averiguarmos o, impacto nos seres vivos a curto e longo } \\
2\end{array}$ \\
& Não gostaria de participar desta equipe, por ser uma energia \\
& de alto custo e perigosa para a nossa saúde.
\end{tabular}

Fonte: Elaborada pela autora. 
Tabela 11 - Respostas dos professores do Questionário Final - Pergunta 3. Número de Respostas da pergunta 3.0 Brasil tem se beneficiado da professores evolução da tecnologia nuclear? Como?

9- SIM

9 Principalmente na medicina; no tratamento e diagnóstico de tumores.

4 Produção de energia

3- Não

Opinaram Atualmente só pesquisas: Angra I e Angra II. Em projeto 2 Angra III.

1

Muito Pouco.

Fonte: Elaborada pela autora.

$\mathrm{Na}$ tabela 12 observa-se a preocupação quanto aos acidentes com material radioativo e com o rejeito nuclear.

Tabela 12 - Respostas dos professores do Questionário Final - Pergunta 4. Número de Respostas da pergunta 4. Vocês conhecem algum Impacto professores Ambiental causado pela utilização da Tecnologia Nuclear? Cite Exemplos.

\begin{tabular}{ll}
\hline 9 & Sim. Goiânia, Chernobyl, Japão (usina de Fukushima) e \\
& cidades de Hiroshima e Nagasaki em 1945. \\
& O problema do lixo atômico, como tornar o material radioativo \\
& menos impactante?
\end{tabular}

Fonte: Elaborada pela autora.

$\mathrm{Na}$ tabela 13 observa-se o interesse dos professores para aprender mais sobre EN na área médica, na produção de energia elétrica e tratamento dos rejeitos. 
Tabela 13 - Respostas dos professores do Questionário Final - Pergunta 5.

\begin{tabular}{cl}
\hline $\begin{array}{c}\text { Número de } \\
\text { professores }\end{array}$ & $\begin{array}{l}\text { Respostas da pergunta 5. Sobre o assunto energia } \\
\text { nuclear, você tem dúvidas ou interesse em saber sobre } \\
\text { qual item? }\end{array}$ \\
\hline 4 & $\begin{array}{l}\text { Área da Saúde } \\
\text { Consequências do mau uso }\end{array}$ \\
3 & $\begin{array}{l}\text { Lixo atômico; a finalização dos contêineres; decaimento } \\
\text { dentro dos contêineres, Custo benefício impacto da Usina }\end{array}$ \\
& $\begin{array}{l}\text { Nuclear } \\
3\end{array}$ \\
\hline
\end{tabular}

Fonte: Elaborada pela autora.

Como mencionado anteriormente, a maioria dos professores não devolveu ou não quis responder o questionário final, assim modificou-se o questionário final para uma atividade com questões múltiplas escolhas, para avaliar o aprendizado do grupo. A ideia surgiu quando a metodologia foi apresentada para alunos do ensino médio, da Escola Estadual Ermano Marchetti, porque houve a necessidade de aplicar uma avaliação para aproximadamente 400 alunos numa versão para o vestibular, foto no APÊNDICE C. Estas avaliações não foram contabilizadas neste trabalho, porque houve a necessidade da devolução das avaliações para os alunos. Portanto, para análise desta quarta etapa, aplicou-se esta versão da atividade para um grupo de seis professores participantes do curso de pós-graduação na Escola de Comunicação e Artes da Universidade de São Paulo, foto no APÊNDICE C.

A seguir, apresenta-se a atividade com as questões múltiplas escolhas, a quantidade entre parênteses na frente do item selecionado pelos professores e as respostas corretas abaixo.

\section{ATIVIDADE}

1. Você é favorável a utilização da Tecnologia da Energia Nuclear para:

( ) Medicina - Diagnóstico. (2)

( ) Produção de Energia Elétrica por ser Energia Limpa. (1)

( ) Irradiar alimentos e materiais cirúrgicos. (2)

( ) Todas as atividades citadas acima. (4)

( ) Nenhuma das atividades. (-) 
2. Sobre impactos ambientais, o que se refere ao Aquecimento Global, foi constatado que a Terra vem sofrendo o aumento de temperatura, alguns acreditam que seja devido a emissão de gases de efeito estufa como Gás Carbônico, Metano, alguns Aerossóis. A produção de energia elétrica que emite menos gases de efeito estufa é:
(A) Nuclear. (3)
(B) Hidrelétrica. (-)
(C) Carvão Mineral. (1)
(D) Produtos do Petróleo. (-)
(E) Nuclear e Hidrelétrica. (2)
Resposta Certa: A

3. O resultado entre as Forças Nucleares pode ser a:

(A) Emissão de Raios X e Partículas Nucleares. (1)

(B) Emissão de Raios X e Gama. (1)

(C) Emissão de Raios Gama e apenas partículas Alfa. (3)

(D) Emissão de Raios X e partículas nucleares. (-)

(E) Emissão de Raios Gama e Partículas nucleares. (1)

Resposta Certa: E.

4. O Tecnécio-99, um radioisótopo muito utilizado em diagnósticos médicos, apresenta meia-vida bastante curta. Ele é produzido a partir do Molibdênio, pela sequência de reações nucleares representadas pelas equações,

$$
{ }_{42}^{99} M o \rightarrow{ }_{43}^{99} T c^{*}+X \quad e \quad{ }_{43}^{99} T c^{*} \rightarrow{ }_{43}^{99} T c+Y
$$

Tc* representa núcleo em estado de energia maior que o fundamental. As emissões $\mathrm{X}$ e Y são, respectivamente:
(A) Partícula Alfa e Partícula Alfa. (1)
(B) Partícula Beta e partícula Alfa. (-)
(C) Partícula Beta e Radiação Gama. (2)
(D) Partícula Alfa e Radiação Gama. (3)
(E) Radiação Gama e Radiação Gama. (-) Resposta Certa: C.

5. O acidente com o Césio-137, em Goiânia, no dia 13 de setembro de 1987, foi o maior acidente radioativo do Brasil e o maior do mundo ocorrido em área urbana. A cápsula de Cloreto de Césio $(\mathrm{CsCl})$ que fazia parte de um equipamento hospitalar usado para radioterapia que utilizava o Césio-137 para irradiação de tumores ou de materiais sanguíneos. Nessa cápsula, havia aproximadamente $19 \mathrm{~g}$ do cloreto de 
césio-137 ( $T_{1 / 2}=30$ anos), um pó branco parecido com o sal de cozinha, mas que, no escuro, brilha com uma coloração azul. Admita que a massa total de cloreto de césio, contida na cápsula, tenha sido recuperada durante os trabalhos de descontaminação e armazenada no depósito de rejeitos radioativos do acidente, na cidade de Abadia de Goiás. Dessa forma, o tempo necessário para que restem $6,25 \%$ da quantidade de cloreto de césio contida na cápsula, e a massa de $\mathrm{CsCl}$ presente no rejeito radioativo, após sessenta anos do acidente, são, respectivamente:
(A) 150 anos e $2,37 \mathrm{~g}$. (-)
(B) 120 anos e $6,25 \mathrm{~g}$. (4)
(C) 150 anos e 9,50 g. (-)
(D) 120 anos e $9,50 \mathrm{~g}$. (1)
(E) 120 anos e 4,75 g. (1)
Resposta Certa: E.

6. Quando uma pessoa está na praia "tomando um Sol", ela é:
(A) Contaminada pela radiação solar. (2)
(B) Irradiada pela radiação solar. (-)
(C) Irradiada somente pela radiação gama. (2)
(D) Contaminada somente pela radiação gama. (2)
(E) Irradiada por material radioativo. (-)
Resposta Certa: B.

7. Assinale a alternativa ERRADA.

(A) $O$ aparelho de raios $X$ e o de radioterapia possuem material radioativo. (2)

(B) $\mathrm{O}$ aparelho de radioterapia emite radiação de partículas e eletromagnética.(-)

(C) $O$ aparelho de raios $X$ não é usado para tratamento. (2)

(D) $O$ aparelho de raios $X$ não emite radiação atômica quando desligado. (2)

(E) $O$ aparelho de radioterapia é utilizado para tratamentos de pacientes com câncer. (-)

Resposta Certa: A.

Aplicado o questionário, o momento mais importante, desta etapa, ocorreu quando os professores depois que entregaram a avaliação preenchida, quiseram saber as respostas certas, o que levou a rediscussões sobre cada questão. 


\section{ROTEIRO PARA APRESENTAÇÃO}

O roteiro para apresentação como Proposta de uma Metodologia para a divulgação da Tecnologia Nuclear é composta por cinco etapas:

$\checkmark$ Questionário Inicial

$\checkmark$ Vídeo de uma Reportagem

$\checkmark$ Palestra Elucidativa

$\checkmark$ Atividade

$\checkmark$ Interação no ETN (para os grupos que visitarem o ETN)

\subsection{Primeira Etapa - Questionário Inicial}

Recomenda-se que o questionário inicial seja respondido em grupos pequenos (duas ou três pessoas) para que cada integrante do grupo tenha a oportunidade de expressar os seus pontos de vista, respeitando a zona de conforto e para contextualizarem o tema. As questões podem ser distribuídas impressas ou exibidas na tela do multimídia e as respostas registradas numa folha, para que sejam recolhidas para análise posteriormente.

\section{O que é Energia Nuclear? Onde pode ser utilizada?}

2. SE você fizesse parte da "Equipe Científica Intelectual" do governo, seria a favor da utilização da Energia Nuclear? Em qual área? Justifique a sua resposta.

3. O Brasil tem se beneficiado da Evolução da Tecnologia Nuclear? Como?

4. Você conhece algum impacto ambiental causado pela utilização da Tecnologia Nuclear? Por favor, cite exemplo (s).

5. Sobre o assunto de Energia Nuclear, você tem dúvidas ou interesse em saber sobre qual item? 


\subsection{Segunda Etapa - Vídeo de uma Reportagem}

Depois de recolher as folhas de respostas, exibir o trecho (7minutos) do vídeo da reportagem Linha Direta Justiça - Césio 137 (CÉSIO137, 2007) apresentado pela Rede Globo de televisão em 2007, figura 1.

\subsection{Terceira Etapa - Palestra Elucidativa}

Após a exibição do vídeo, poderá iniciar a palestra elucidativa utilizando os slides, figuras 2 até 29 , com o embasamento teórico ${ }^{6}$.

\subsubsection{Discussão das causas do acidente com o aparelho de radioterapia em Goiás (1987) e a sua utilização}

Slide da figura 2: Pergunta-se ao público, buscando a interatividade, quais foram às causas do acidente com o aparelho de radioterapia. Poderá haver respostas como: os responsáveis pelo acidente foram os catadores de material reciclável que retiraram o aparelho e violaram a cápsula contendo Césio 137; ou mesmo, que os principais responsáveis foram os donos da clínica, os órgãos públicos de fiscalização e controle, pois estes detinham obrigatoriamente conhecimento sobre EN e falharam no descomissionamento ${ }^{7}$ do aparelho de radioterapia.

Este é um momento muito importante para que se estabeleça um ambiente de confiança durante toda a intervenção porque o palestrante apresenta o seu primeiro ponto de vista, depois de ter ouvido com atenção as colocações do público. Por esta razão, com segurança, pode-se afirmar que todas as respostas acima citadas são coerentes, porque os coletores da reciclagem, pela falta de conhecimento, violaram a blindagem que protegia o material radioativo; os donos da clínica responsáveis pelo aparelho falharam com a sua segurança e os órgãos do governo ligados a fiscalização e descomissionamento do aparelho de radioterapia também, não dando o tratamento adequado ao material radioativo.

\footnotetext{
${ }^{6}$ Slides da Apresentação disponével: https://www.youtube.com/watch?v=g9UcSgwQpH4 ${ }^{7}$ Refere-se à desativação de todo um empreendimento ou parte dele.

Fonte: http://www.sinergiaengenharia.com.br/o-descomissionamento-e-o-meio-ambiente/
} 


\section{Figura 2 - Quais foram as causas do acidente com o aparelho de Radioterapia}

\section{ERRO NO DESCOMISSIONAMENTO DO}

APARELHO

- pelo dono da clínica e órgãos responsáveis.

\section{FALTA DE CONHECIMENTO:}

- Do dono do ferro velho que se apropriou e violou o aparelho e das pessoas amigas, vizinhas que manusearam

Fonte: Elaborada pela autora.

Muito se aprende com os acidentes ocorridos com material radioativo no mundo, principalmente para estabelecer normas e técnicas de padrões internacionais, da Agência Internacional Energia Atômica (AIEA), as quais a CNEN segue para licenciar, fiscalizar instalações nucleares, como reatores, fábricas do ciclo do combustível, instalações que utilizam radioisótopos, na medicina, indústria e atividades de pesquisa no Brasil (CNEN, 2015).

Slide da figura 3: Estabelecido o ambiente tranquilo, de confiança e interativo, o que gera credibilidade, inicia-se a fundamentação da EN. Com a contextualização do trecho da reportagem, pergunta-se: “- Para que serve um aparelho de radioterapia?” O público pode confundir o aparelho de radioterapia com o aparelho de raios $X$, portanto explica-se que o aparelho de radioterapia é um importante aliado para realizar tratamentos para pacientes com câncer. O aparelho possui uma fonte com material radioativo que no momento da sua utilização, é deslocada de sua posição de blindagem total (feito de chumbo e aço inoxidável), para frente de um orifício, que permite a passagem de um feixe de radiação que incide na região a ser tratada. Após o uso, a fonte é recolhida para a posição de segurança (CARDOSO, 2015). 
Figura 3 - Aparelho de radioterapia possui material radioativo, Césio ou Cobalto.

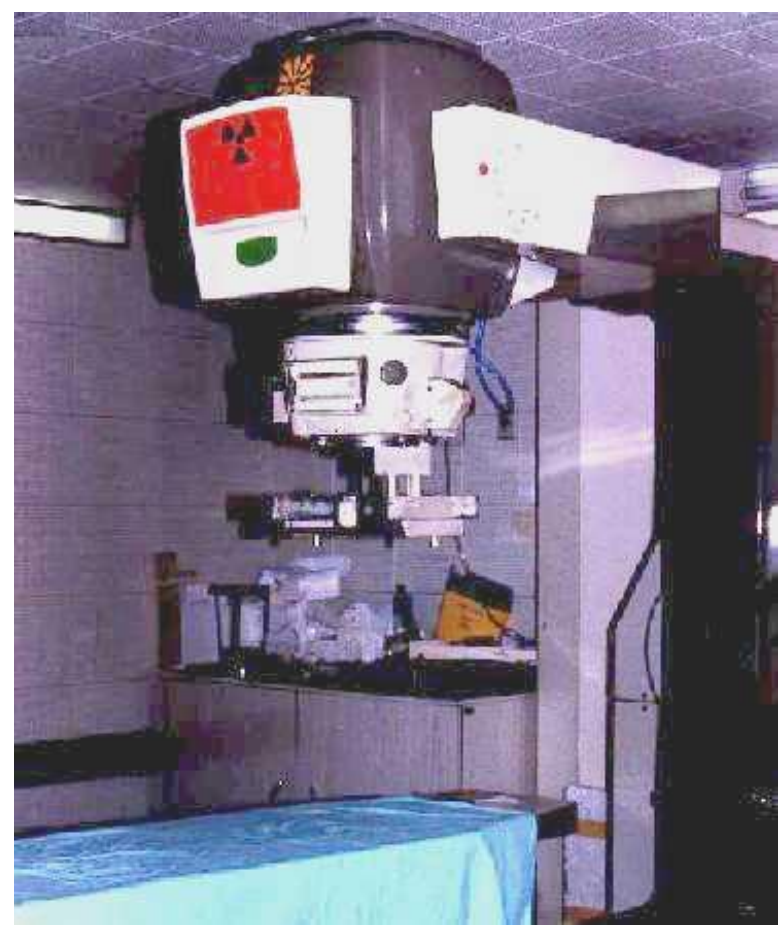

Fonte: https://mastologia.wordpress.com/tag/cobalto-60/

Slide da figura 4: Para apresentar uma das formas que a tecnologia evoluiu no tratamento do câncer, o Acelerador Linear (Linac) que está substituindo o aparelho com material radioativo, Césio ou Cobalto. O LINAC em funcionamento emite Raios $X$ de maior energia que são depositados na região do corpo que se deseja tratar e como não possui material radioativo, quando desligado não emite radiação de raios X. (SCAFF, 2015). Importante observar que os profissionais da saúde devem obedecer às normas de procedimento para se proteger da radiação toda a vez que forem tratar um paciente. 
Figura 4 - Acelerador Linear (LINAC) não possui material radioativo, ao ser desligado não emite radiação.

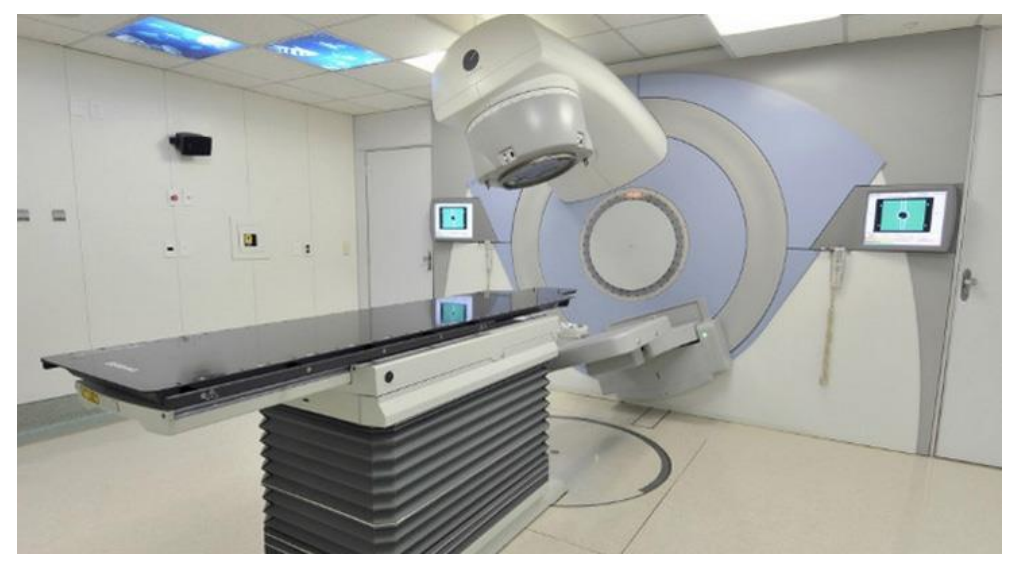

Fonte: $\quad$ http://radiologia.blog.br/radioterapia/radioterapia-veja-a-evolucao-da-radioterapiapassado-presente-e-futuro

\subsubsection{Radioatividade e a Estrutura Nuclear}

Slide da figura 5: Pergunta-se onde tem radioatividade? Será que as pessoas que trabalham numa usina nuclear é como o Homer Simpson, sem conhecimento na área nuclear? Pode-se dizer que o Sol emite radiação nuclear que interage com a Terra; o universo emite radiações cósmicas; certas regiões como em Guarapari no estado de Espírito Santo emite radiação nuclear, por ter na composição das areias monazíticas minerais radioativos (OKUNO, 2007). Portanto, não é só dentro da usina nuclear que tem material radioativo. Em relação aos funcionários que trabalham nas usinas nucleares brasileiras, a Eletrobrás Eletronuclear empresa que tem a finalidade de operar e construir usinas termonucleares no Brasil, em conformidade com a Constituição Federal de 1988, somente está autorizado a efetuar contratações por meio de concursos públicos (ELETRONUCLEAR $\left.{ }^{1}, 2017\right)$. 
Figura 5 - Radioatividade - Elemento da natureza.

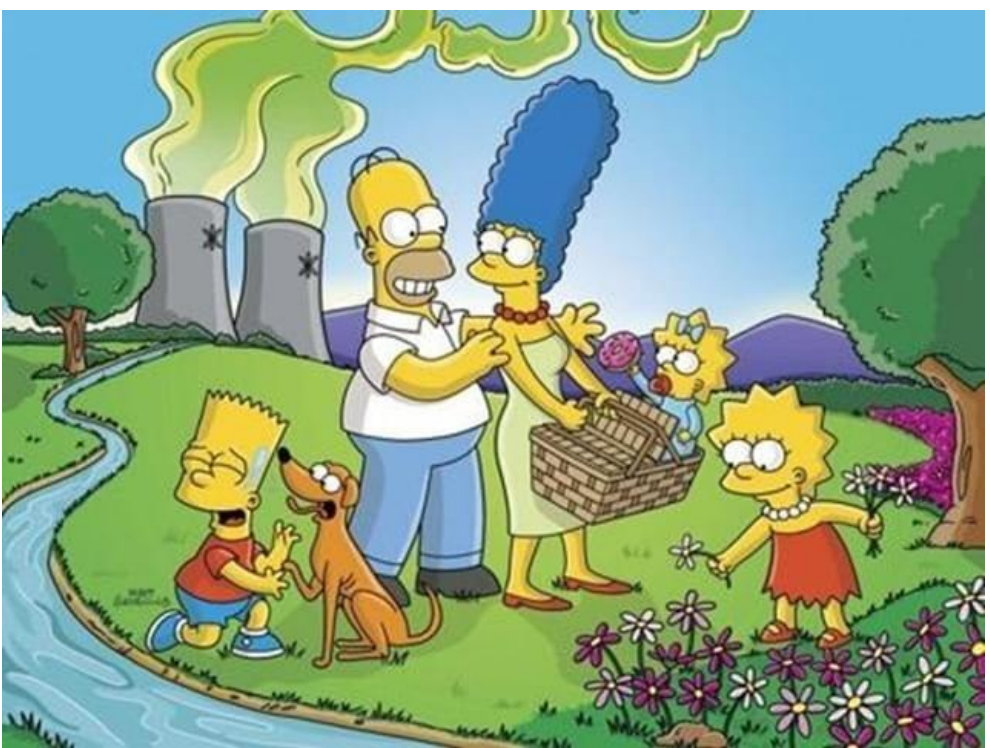

Fonte: $\quad$ https://www.megacurioso.com.br/desenhos-animados/57698-os-simpsons-fazemaniversario-e-presentamos-25-curiosidades-sobre-a-serie.htm

Slide da figura 6: Apresenta-se a Tabela Periódica dos Elementos, explicando que a matéria é constituída de um ou mais desses elementos, que o Césio ou Urânio são elementos que estão na natureza e o homem retira e utiliza para diversos benefícios. Tudo que se conhece na natureza é formado por átomos, que ocorrendo combinações com átomos formam moléculas.

Figura 6 - Tabela Periódica dos Elementos - Toda a matéria é formada por um ou mais destes elementos.

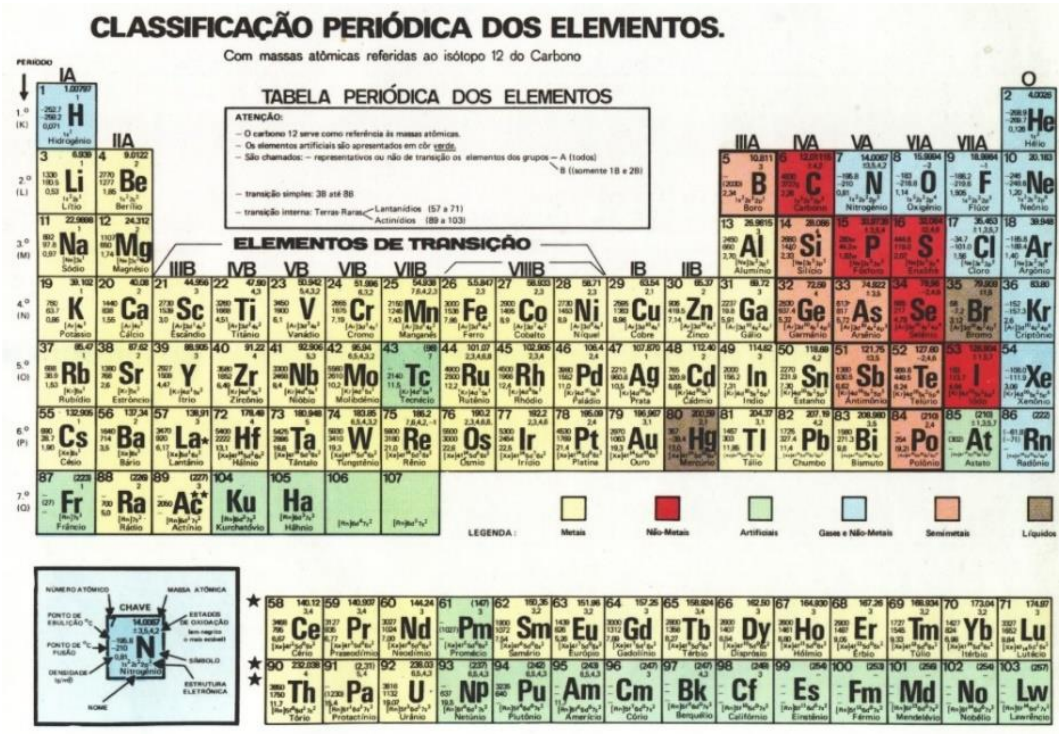

Fonte: http://www.infoescola.com/quimica/tabela-periodica/ 
Slide da figura 7A: O casal Marie e Pierre Curie, cientistas que estudaram as características da radiação emitida por minérios como o urânio. Beneficiaram, em condições precárias, no laboratório, oito toneladas de minério para um grama de sal de rádio. (SEGRÈ, 1987).

Slide da figura 7B: A visualização da rocha que contém o minério e ao lado o Césio beneficiado.

Figuras 7A. Casal Curie $^{8}$ - Precursores do estudo sobre radioatividade - No laboratório simplório, beneficiaram oito toneladas em um grama de sal de Rádio. 7B. Rocha contendo o minério na sua forma natural e os sais de Césio beneficiado ${ }^{9}$.

(7B)
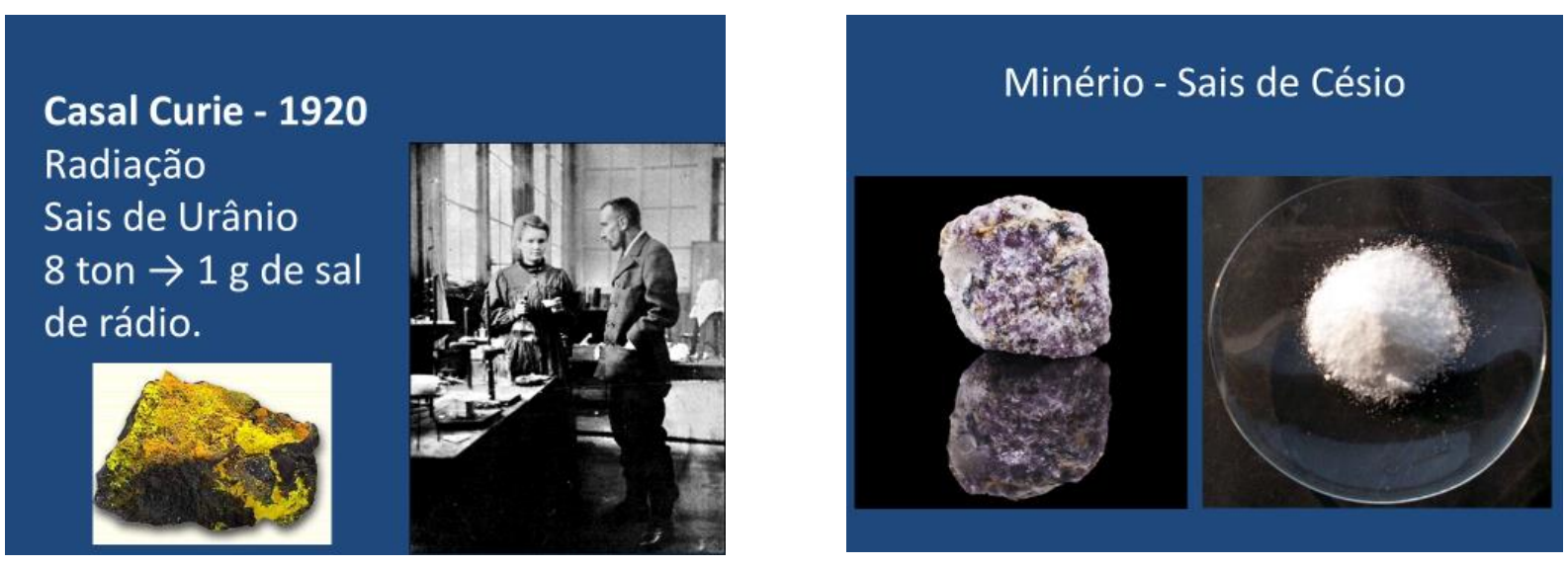

Slide da figura 8A: Para o entendimento da origem da radiação nuclear, necessário lembrar que o núcleo de um átomo é constituído por núcleons (prótons e nêutrons), podendo exemplificar primeiro, o núcleo do Berílio (por ter poucos núcleons facilita o cálculo). Utilizando as informações da tabela periódica, o número atômico (Z) é igual a 4 (quantidade de prótons) e o número de massa (M) igual a 9 quantidade de núcleons (prótons e nêutrons), portanto o número de nêutrons é igual a cinco porque é a diferença entre a massa atômica e o número atômico.

\footnotetext{
${ }^{8}$ Fontes: http://beytudodebom.com.br/quimica/uranio.php e https://historiazine.com/marie-curie-a-dama-radioativa-8b0d30ede451

${ }^{9}$ http://alunosonline.uol.com.br/quimica/cesio-137.html e http://www.quimlab.com.br/guiadoselementos/cesio.htm
} 
Slide da figura 8 B: Analogamente, apresenta-se o Urânio ( $Z=92$ e $M=238$ ) logo a quantidade de prótons é igual a noventa e dois e o de nêutrons cento e quarenta e seis.

Figuras 8A - Exemplo do Berílio $^{10}$ e 8B - Urânio, quantidade de núcleons, prótons e nêutrons ${ }^{11}$.

$(8 \mathrm{~A})$

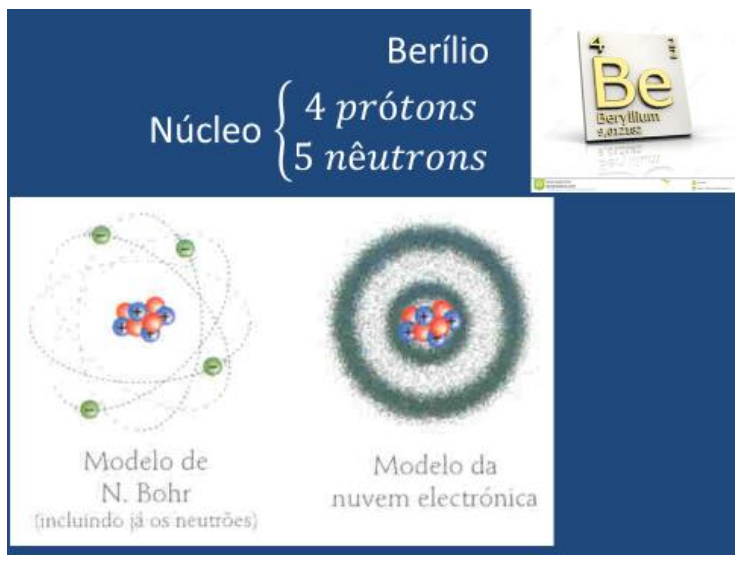

(8B)

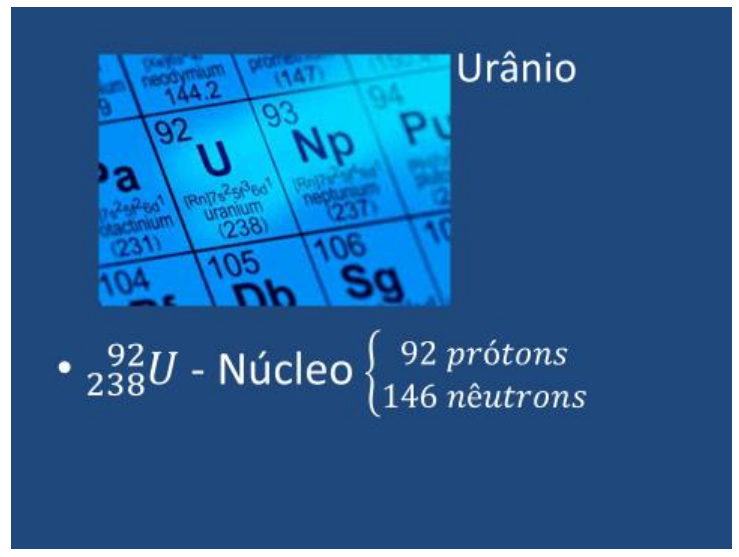

O núcleo de um átomo permanece coeso se as forças nucleares de atração e de repulsão estiverem em equilíbrio entre os núcleons. Existe a força elétrica de repulsão (de Coulomb) entre os prótons por terem cargas positivas (entre os nêutrons não possuem esta força por não terem cargas). Para que o núcleo permaneça coeso existe uma força de atração que é denominada força forte, existente entre os núcleons, prótons e nêutrons. A radiação nuclear é o resultado do desequilíbrio entre estas forças, isto é, o núcleo fica instável, podendo emitir radiação eletromagnética ou partículas (matéria) decaindo e se tornando estável (HALLIDAY et al, 2008).

\footnotetext{
Fontes: $\quad$ https://pt.dreamstime.com/imagens-de-stock-ber\%C3\%ADlio-da-tabela-deelementos-peri\%C3\%B3dica-image6294024 e http://imaginariodomario.blogspot.com.br/2012/02/nuvens.html ${ }^{11}$ http://www.gettyimages.pt/fotos/ur\%C3\%A2nio?excludenudity=true \&sort=mostpopular\&me diatype $=$ photography $\&$ phrase $=$ ur $\% \mathrm{C} 3 \% \mathrm{~A} 2$ nio
} 


\subsubsection{Decaimentos Nucleares Alfa, Beta negativo e Gama}

Slide da figura 9: O decaimento Alfa ( $\alpha$ ) é a emissão de um núcleo de átomo de Hélio (dois prótons e dois nêutrons) por um núcleo instável, como o Plutônio, que se transforma num átomo de Urânio. Pode-se observar que o número de núcleons inicial do Plutônio (núcleo pai) é igual à soma dos núcleons da partícula $\alpha$ mais do Urânio (núcleo filho). O Urânio tendo energia para emitir outra partícula $\alpha$, se transforma em Tório (HALLIDAY et al, 2008).

Figura 9 - Decaimento Alfa ( $\alpha$ ). Plutônio ao emitir a partícula $\alpha$ se transforma em Urânio e este pode emitir outra partícula $\alpha$ se transformando em Tório.

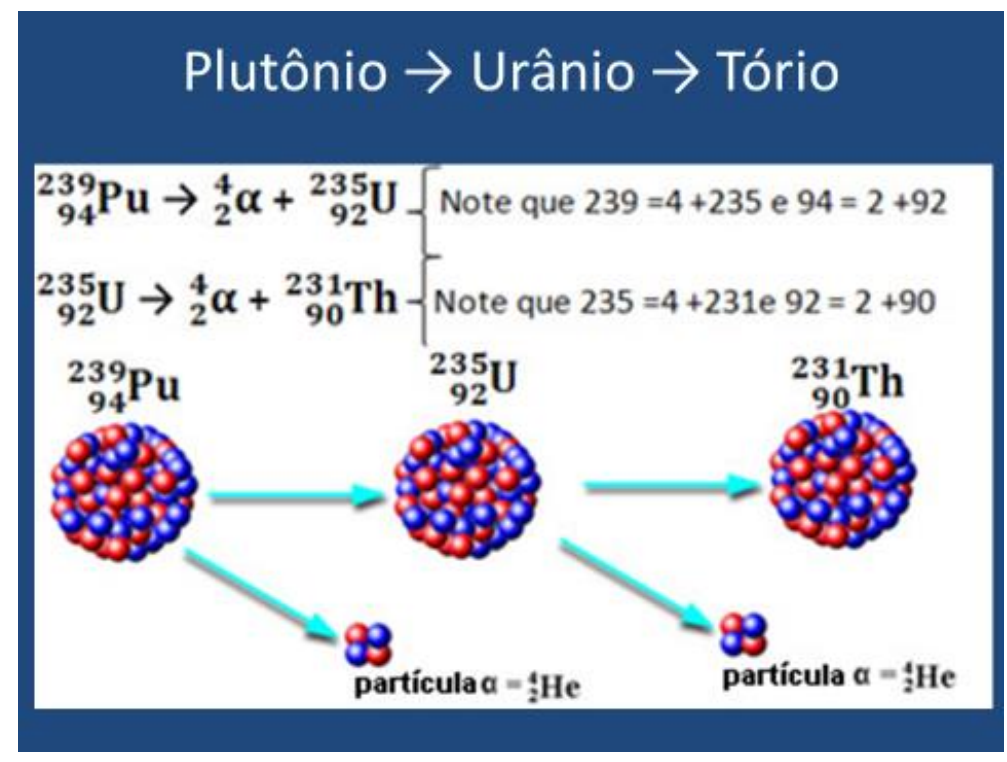

Fonte: http://mundoeducacao.bol.uol.com.br/quimica/primeira-lei-soddy.htm

Slide da figura 10: Explica-se o decaimento Beta negativo ( $\beta^{-}$) que é a emissão de $\beta^{\text {- }}$ (que possui a mesma massa de repouso de um elétron atômico e unidade de carga negativa) por um núcleo instável por ter excesso de nêutrons. No caso do Césio, no seu núcleo, um nêutron se transforma em um próton mais um elétron e um antineutrino. O núcleo por ter energia, emite o elétron e o antineutrino se transformando em Bário instável, que por ainda ter energia devido à redistribuição de cargas elétricas, emite esta energia na forma de radiação eletromagnética, raios gama $(\gamma)$ que não possuem carga nem massa, transformando-se em Bário estável (SCAFF,2015). 
Figura 10 - Decaimento Beta Negativo $\left(\beta^{\top}\right)$. Um nêutron se transforma em um próton mais uma partícula $\beta^{-}$e um antineutrino $(\bar{v})$ no núcleo do Césio e este tendo energia emite as partículas $\beta^{-} \mathrm{e} \bar{v}$, transformando-se no Bário instável que ao emitir raios gama $(\gamma)$ se torna estável.

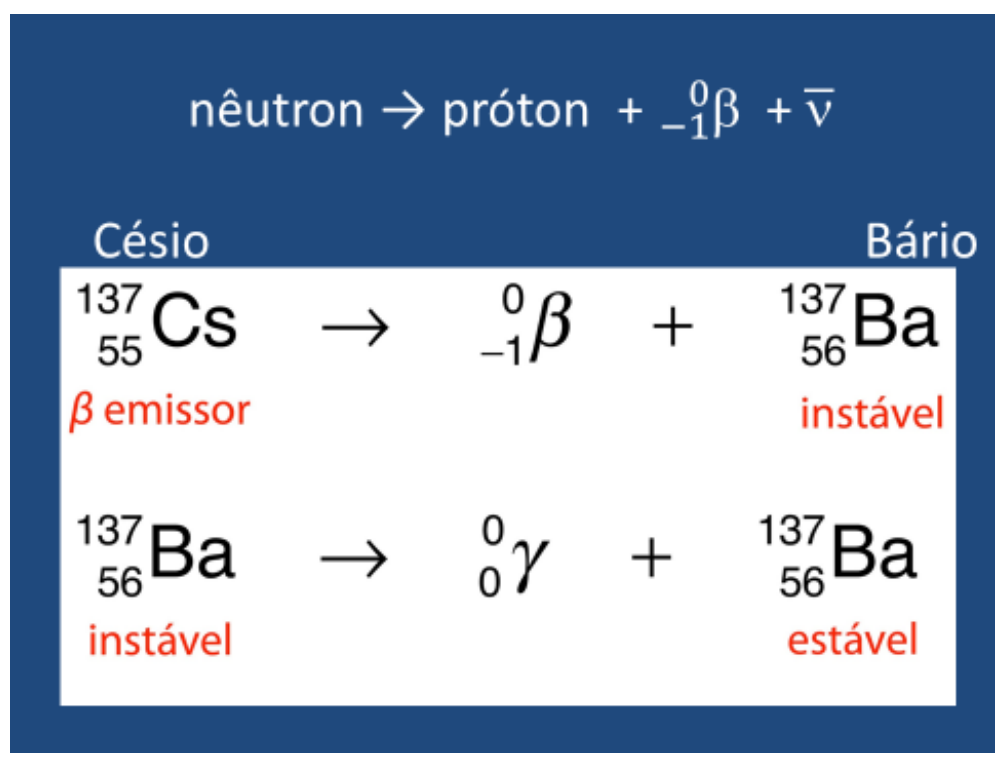

Fonte: Elaborada pela autora.

Slide da figura 11: Retomam-se os tipos de decaimentos explicados, Alfa, Beta e Gama, reforçando que Alfa e Beta são radiações corpusculares por terem massa, e o raio gama é radiação eletromagnética não possuem nem massa nem carga.

Figura 11 - Tipos de Radiação - Alfa, Beta e Gama.

\section{Tipos de Decaimento: Alfa, Beta e Gama}

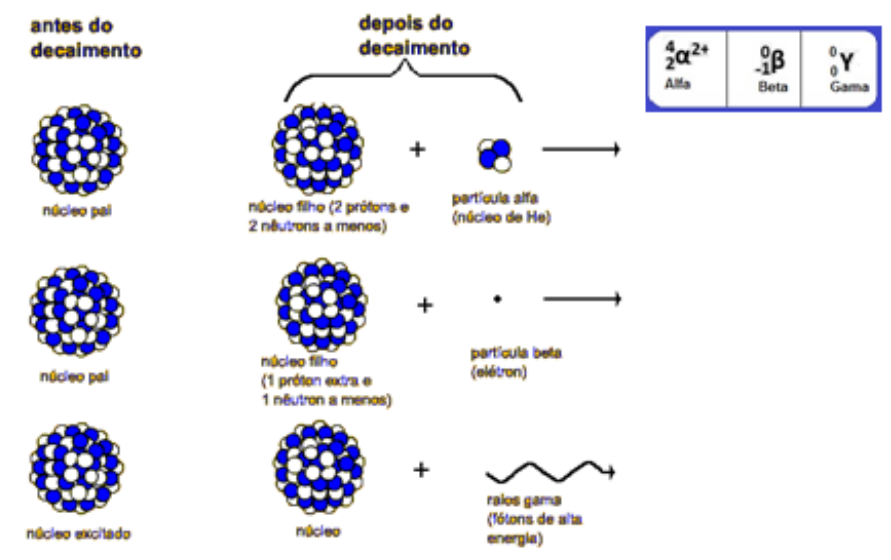

Fontes: https://www.if.ufrgs.br/cref/radio/capitulo1.htm e http://www.marquecomx.com.br/2013/02/radioatividade-radiacoes-alfa-beta-e.html 


\subsubsection{Proteção Radiológica}

Slide da figura 12: Para utilizar material radioativo é necessário seguir as normas e os princípios básicos de proteção para os pacientes, o público, o meio ambiente, mas principalmente os profissionais e pesquisadores que lidam diariamente com a radiação. Em relação ao paciente, é individual, se estuda a dose necessária para irradiar a região tanto para tratamento como também para diagnóstico, preservando da melhor forma possível os órgãos saudáveis. Os profissionais tanto da saúde como os que trabalham nas usinas e nos reatores nucleares, seguem procedimentos como: reduzir o tempo de exposição; aumentar a distância da radiação e sempre que possível utilizar as blindagens adequadas. Estes profissionais também utilizam um dosímetro, para ter controle da dose absorvida durante um intervalo de tempo (SORDI, 2017).

Para realizar a blindagem da radiação emitida por material radioativo, pode explicar que a partícula $\alpha$ pode ser blindada por uma folha de papel, a partícula $\beta$ por ser menor, transpassa a folha de papel, mas pode ser blindada pelo alumínio e a radiação eletromagnética $\gamma$, que transpassa uma folha de papel e o alumínio, pode ser blindada com o chumbo (CARDOSO, 2015).

Figura 12 - Proteção Radiológica - Blindagem para a radiação Alfa, Beta e Gama.

\section{Blindagem - Proteção}

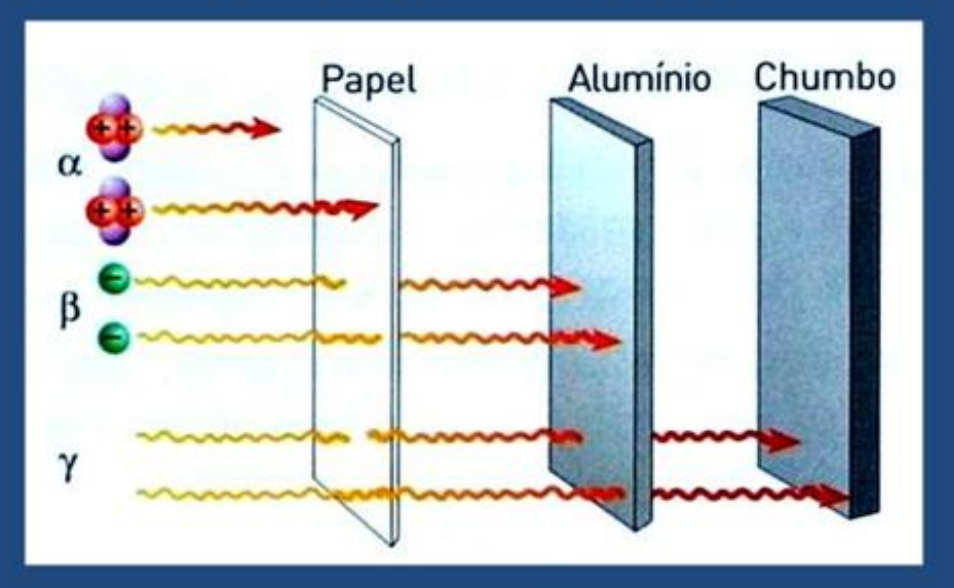

Fonte: http://bdtd.ufscar.br 


\subsubsection{Contaminação e Irradiação (material radioativo)}

Slides das figuras 13 A e 13 B: Como curiosidade e para descontração, apresentam-se produtos comercializados nos anos trinta de forma equivocada por conter na sua composição material radioativo, em cremes de beleza para o rosto, nos relógios os mostradores e os ponteiros eram pintados com tinta com material radioativo para brilhar no escuro, supositórios, sabonetes para banho e pasta de dente. Naquela época, com a descoberta de alguns benefícios da radioatividade, explorou-se comercialmente a sua utilização sem que houvesse controle da dose que a pessoa iria receber. As principais vítimas foram os trabalhadores da produção, pela exposição excessiva, distância mínima e sem blindagem do material radioativo, e também por se contaminarem inalando ou engolindo material radioativo (OKUNO, 2007).

Figuras $13 \mathrm{~A}$ - Produtos comercializados nos anos $30 \mathrm{com}$ material radioativo. Creme para o rosto e relógios. 13 B - Supositórios, sabonete para banhos e creme dental.

(13A)

(13B)
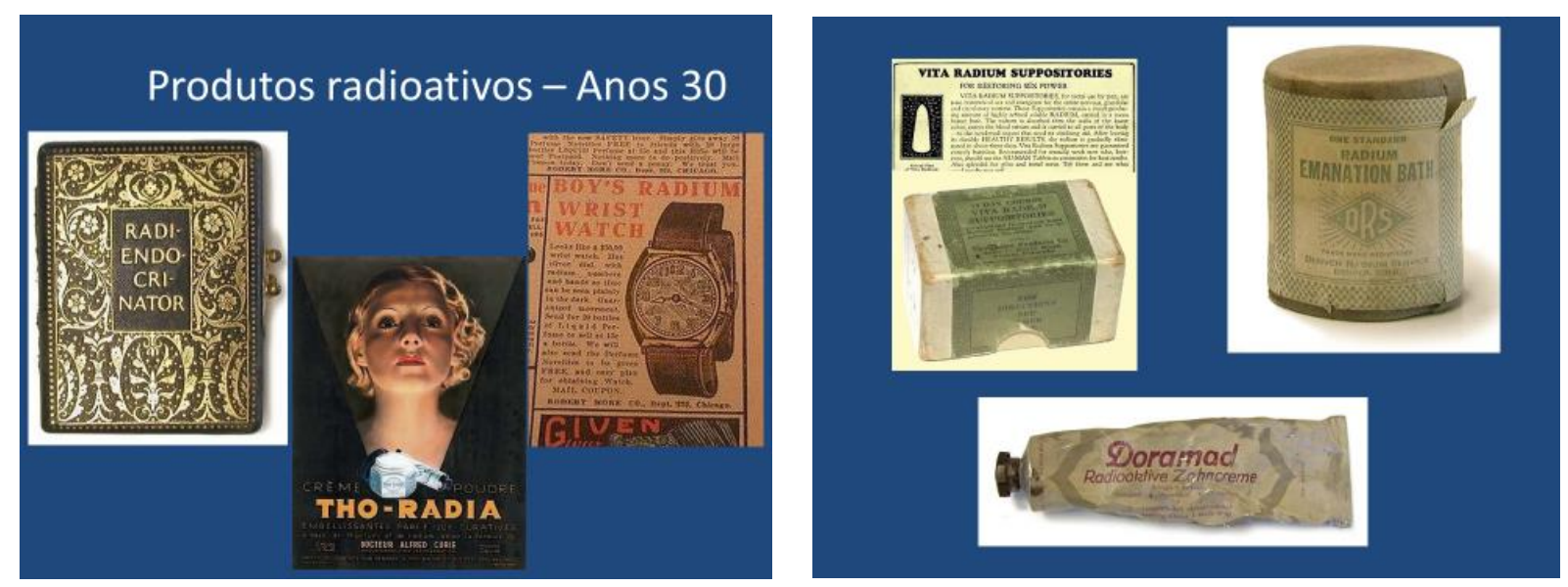

Fonte: http://bondosos.blogspot.com.br/2009/07/produtos-radioativos-que-as-pessoas.html

Neste momento, explica-se a diferença entre Contaminação e Irradiação. A contaminação ocorre quando algum material radioativo é depositado em algum ambiente ou mesmo se uma pessoa o inala, ou ingere ou é aplicado na forma de radiofármacos. Estes locais ou pessoa tornam-se fontes radioativas, portanto estão contaminados (OKUNO et al, 1982). A Irradiação ocorre quando se é exposto à radiação eletromagnética, raios $X$ ou gama como exemplo. 


\subsubsection{Raios-X (Energia Atômica)}

Slide da figura 14 A: Introduz-se o assunto sobre energia atômica, perguntando se ao realizar um exame radiológico o paciente é contaminado ou é irradiado?

Slide da figura 14 B: E ao tomar banho de Sol, o cachorrinho está sendo irradiado ou contaminado? Em ambos os casos, estão sendo irradiados, não há contaminação por não haver o depósito de algum tipo de material radioativo tanto no paciente como no caso do cachorrinho.

Figuras 14 A - Raios X: Irradia ou Contamina? 14 B - Banho de Sol: Irradia ou Contamina?

(14 A)

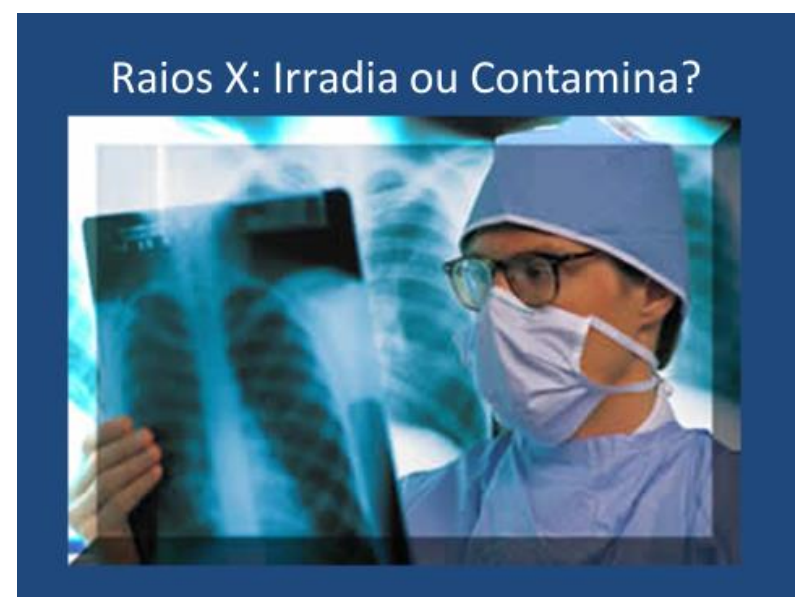

(14 B)

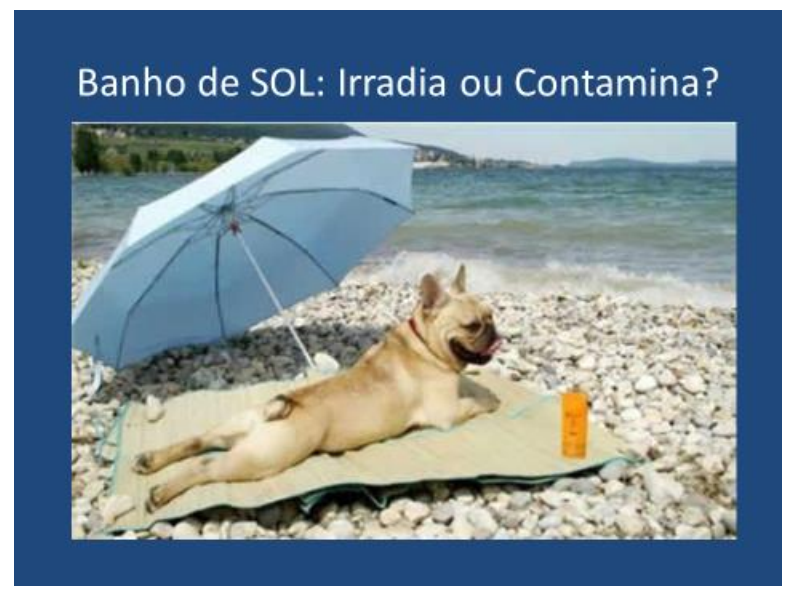

Fontes: https://www.portalmedicos.com.br/radiologia-o-grande-auxilio-da-medicina/ e http://blog.meuamigopet.com.br/watch-full-movie-life-2017/

Slide da figura 15: Pode-se perguntar ao público, se ao utilizar de raios gama para esterilização de materiais hospitalares e de alimentos para aumentar o poder de compra e a sua durabilidade, são contaminados ou irradiados? Como resposta, afirma-se que os elementos são irradiados por uma fonte radioativa e não há contaminação dos materiais hospitalares e dos alimentos. Nos alimentos, como a cebola, ao serem irradiados por raios gama, não altera a sua qualidade e em meses de armazenamento não há brotamento, enraizamento e apodrecimento (CARDOSO, 2015). 
Figura 15 - Raios Gama: Irradia ou Contamina?

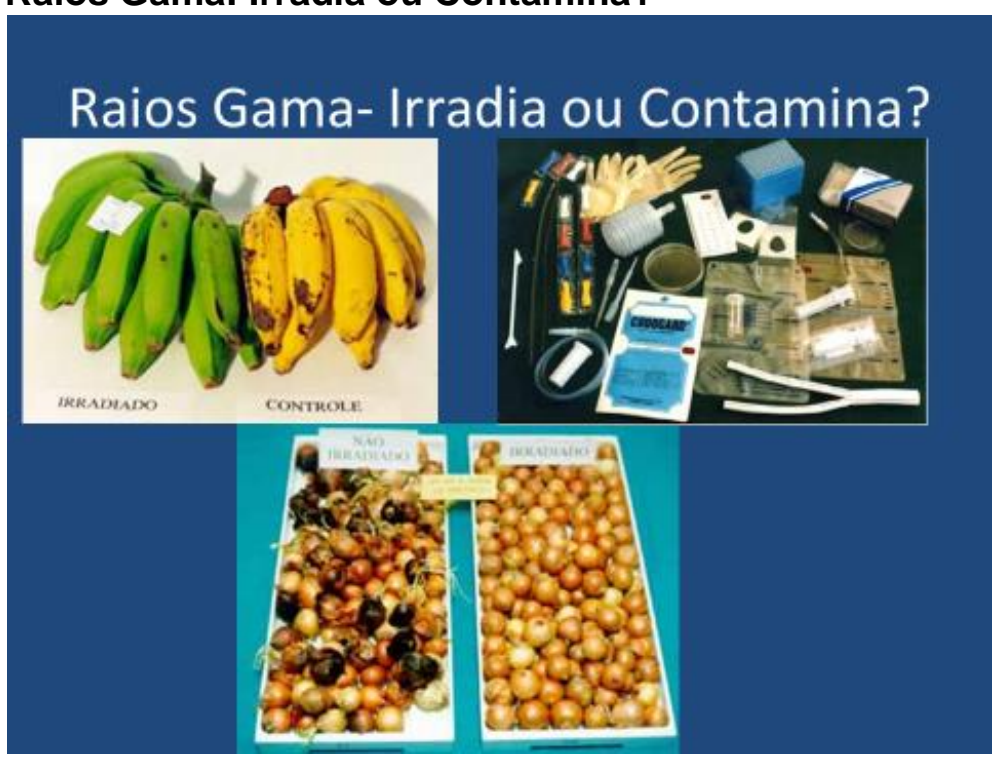

Fontes:

https://sites.google.com/site/radiacao12c3/esmiucamn/alimentos-irradiados-parte-ii https://maesso.wordpress.com/2011/09/18/iradiacao-de-alimentos-ja-e-legal-no-brasil/ http://alunosonline.uol.com.br/quimica/radioatividade-na-industria.html

Slide da figura 16: De forma análoga, ao utilizar o aparelho de micro-ondas, para o aquecimento ou cozimento de alimentos, ele irradia ondas eletromagnéticas, frequência de $2450 \mathrm{GHz}$, que interagem (entram em ressonância) com as moléculas de água, transformando em calor, pelo aumento da movimentação das moléculas. Neste caso, o aparelho não possui material radioativo, portanto não há como contaminar os alimentos, ele possui magnetron que produz as micro-ondas (CARVALHO,2005). 
Figura 16 - 0 aparelho de micro-ondas irradia o alimento ou contamina?

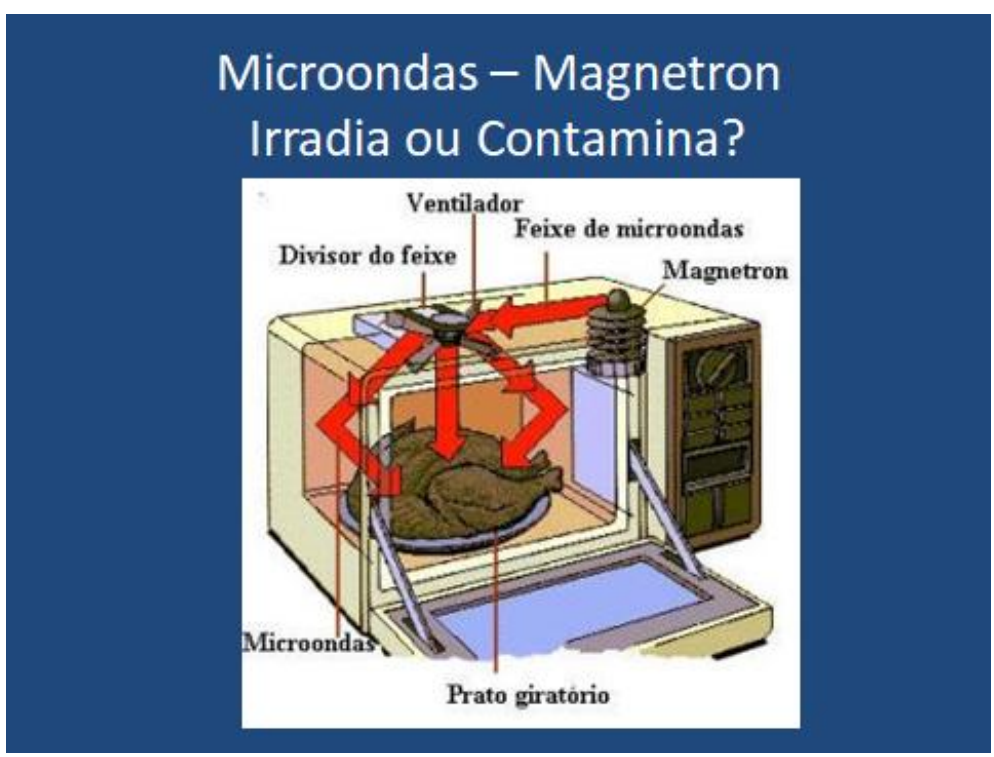

Fonte:

https://bibliblogue.wordpress.com/2010/02/11/bibliciencia-8-aplicacoes-dasradiacoes-microondas-por-hugo-fernandes/

Slide da figura 17: Pergunta se a pessoa da radiografia foi contaminada ou irradiada. Pode-se afirmar que ela foi irradiada pelos raios $\mathrm{X}$ e talvez contaminada com bactérias que entraram em contato com o corpo, quando introduziram a faca na sua cabeça.

Figura 17 - Raios X: Irradiou? Contaminou?

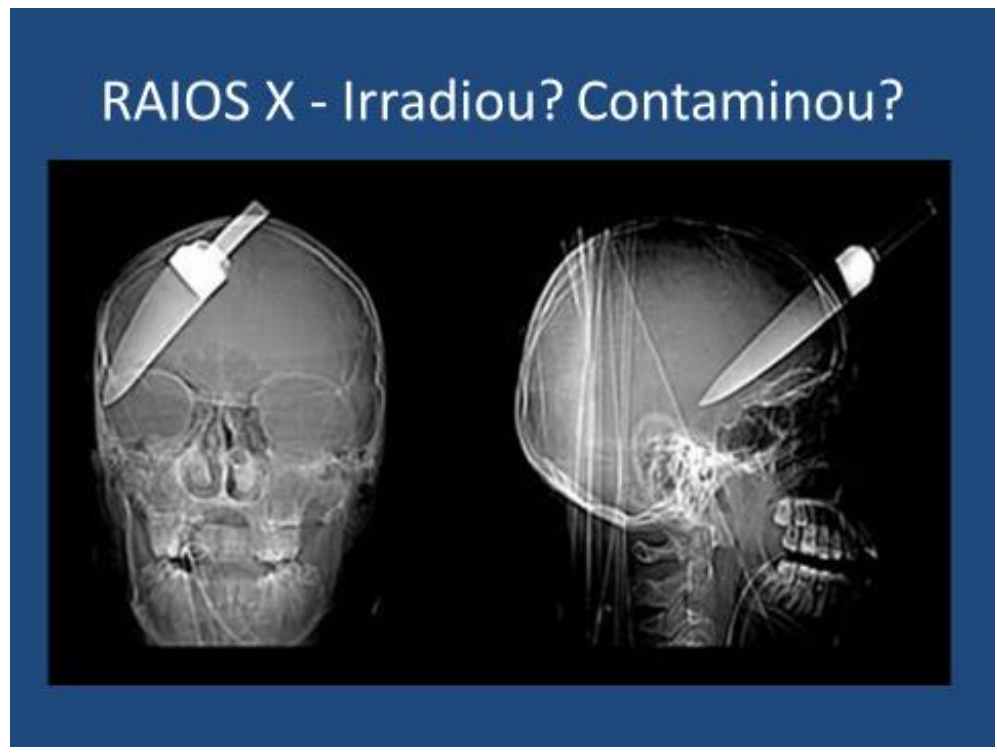

Fonte:http://g1.globo.com/Noticias/Mundo/0,,MUL786502-5602,00-

RADIOGRAFIA+DE+JOVEM+BRITANICO+ESFAQUEADO+CHOCA+O+MUNDO.html 
Slide da figura 18: Para lembrar a importante contribuição para a ciência em 22 de dezembro 1895, Wilhelm Conrad Röntgen, obteve a primeira imagem de uma parte do corpo de uma pessoa, dos ossos da mão da sua esposa Anna Bertha Ludwing em chapas fotográficas utilizando os raios X (OKUNO,2007).

\section{Figura 18 - Primeiro Raios $X$ - Röntgen obtendo a primeira imagem radiográfica dos ossos da mão da sua esposa.}

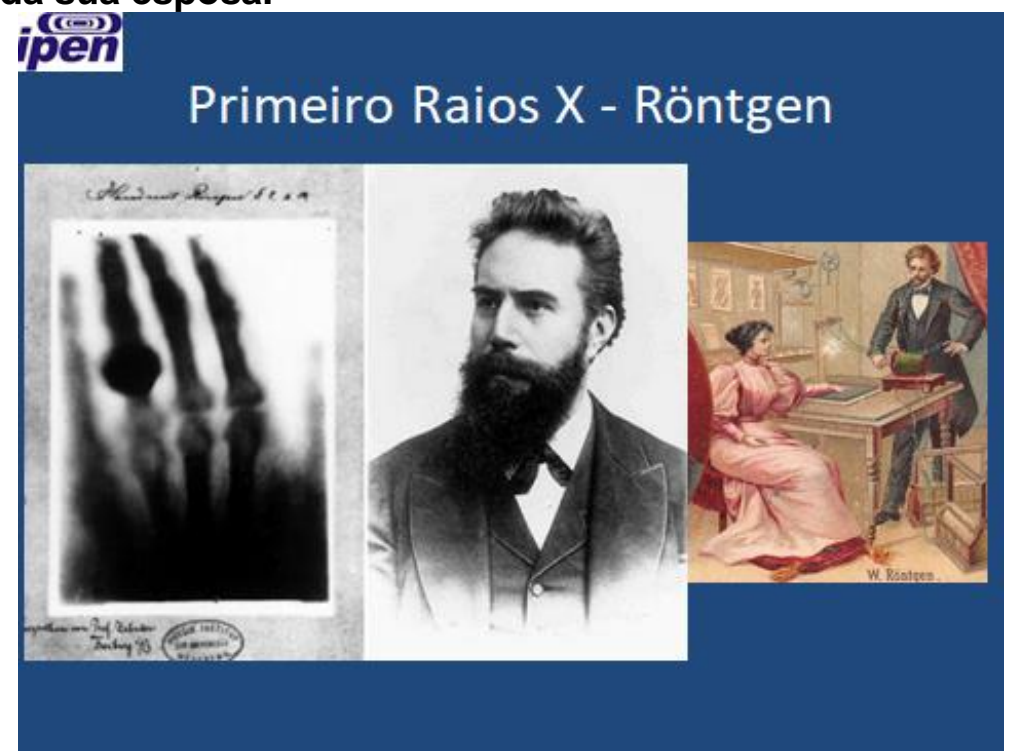

Fonte: https://hypescience.com/27195-primeiros-raios-x/

Slide da figura 19: Explica-se que os raios X produzidos no aparelho de radiologia, não têm origem no núcleo do átomo, mas na sua eletrosfera, por isso é energia atômica. O aparelho de radiografia possui um tubo de raios catódicos e dentro dele dois eletrodos onde elétrons são acelerados, entre eles, por uma diferença de potencial. Ao colidirem com um alvo ocorrem dois fenômenos: ao desacelerar, a energia cinética dos elétrons se transforma em energia de raios $X$, radiação de freamento (bremsstrahlung) e produção de raios $X$, quando o elétron acelerado atinge um elétron que está na eletrosfera do átomo do alvo, retirando-o da camada mais interior, deixando vago o lugar, quando um elétron da camada mais exterior da eletrosfera decair para a camada mais interna, neste lugar vago é emitido um fóton de Raios X característico (HALLIDAY,2008). Por esta razão, o aparelho de radiologia não há como contaminar, por não possuir material radioativo, ao ser desligado não emite radiação de raios $X$. 
Figura 19 - Os raios $X$ são produzidos dentro de um tubo de raios catódicos. Raios $X$ - não é Energia Nuclear

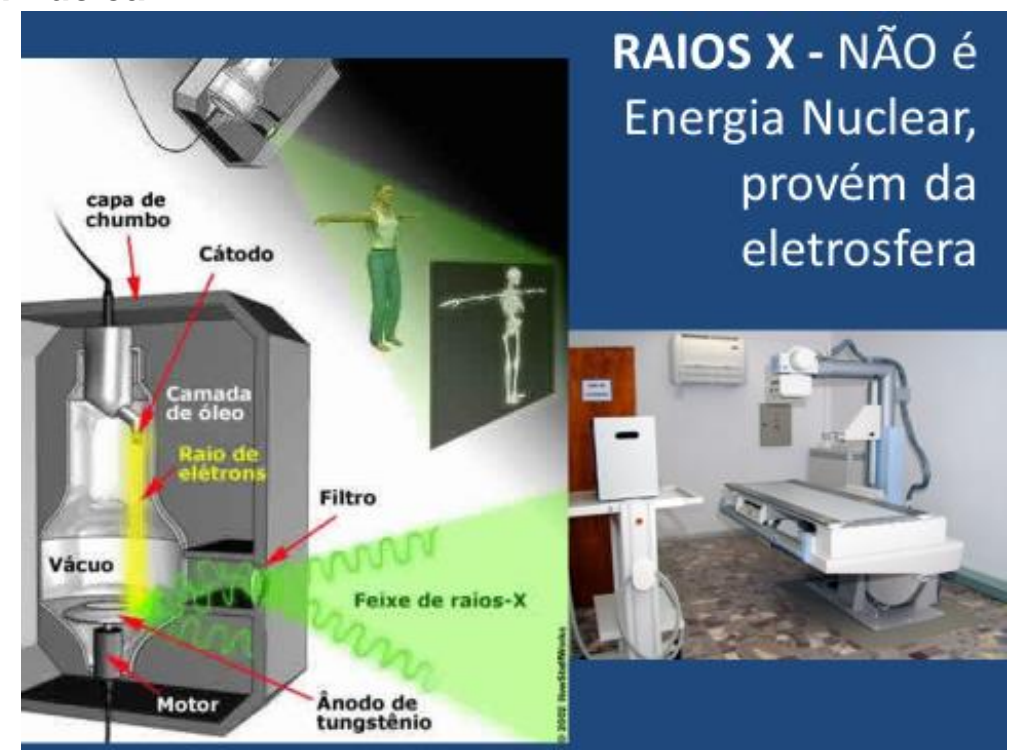

Fontes:

http://papofisico.tumblr.com/post/35666207687/como-funciona-umam\%C3\%A1quina-de-raio-x e http://abc-da-radiologia.blogspot.com.br/2011/10/072-osistema-urinario.html

\subsubsection{Radiofármacos (sua utilização e Meia-Vida)}

Slide da figura 20: Pode perguntar se um paciente ao realizar um exame de cintilografia óssea é irradiado ou contaminado, forma para introduzir a Medicina Nuclear que atualmente é um forte aliado para realização de exames para diagnósticos, tratamentos e estudos de doenças. Para realizar o exame de cintilografia óssea, é administrado um radiofármaco específico que tem afinidade com os ossos, o Tecnécio metaestável $\left({ }^{99 \mathrm{~m}} \mathrm{Tc}\right)$, que emite a radiação $\gamma$ detectada por um aparelho chamado câmaras-gama, para a obtenção da imagem diagnóstica (ARAÚJO, 2005). Neste caso o paciente fica contaminado com material radioativo, porém somente por um tempo determinado pela meia-vida do radiofármacos utilizado. 
Figura 20 - Exame de cintilografia óssea: Irradia ou contamina?

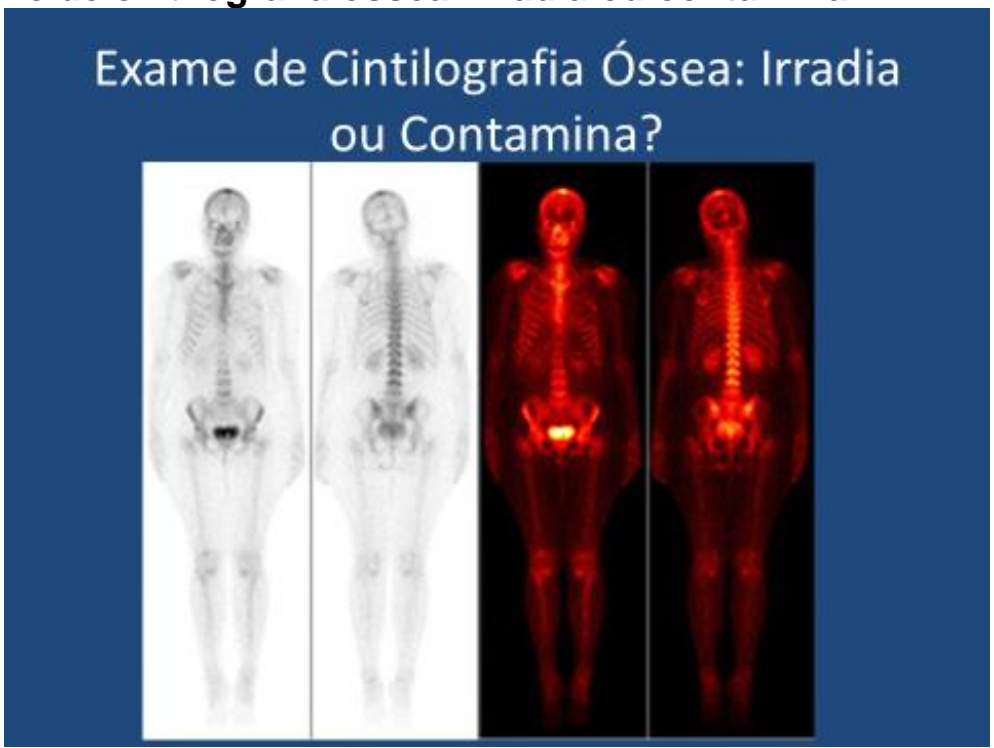

Fonte: http://www.prostata.com.br/outros-exames.html

O conceito da meia vida pode ser apresentado como o tempo necessário para que um radiofármaco tenha o seu número de desintegrações por unidade de tempo reduzido à metade (ZIESSMAN, 2015). Utilizando os dados da tabela dos geradores de radiofármacos, tabela 14, tomemos o exemplo do Tecnécio metaestável $\left({ }^{99 m} \mathrm{Tc}\right)$ que possui a meia vida de seis horas que ao se desintegrar por transição isométrica $(\mathrm{TI})$, quando o núcleo está durante um período de tempo excitado e emite raios gama. Pode-se enfatizar com os dados da tabela, que o ${ }^{99 \mathrm{~m}} \mathrm{Tc}$ ao decair emite raios gama de baixa energia, $140 \mathrm{keV}$, comparado aos outros radiofármacos.

Tabela 14 - Tabela de geradores de radiofármacos. $0^{99 m}$ Tc possui a meia vida de $6 \mathrm{~h}$ e por Transição Isométrica emite raios gama de baixa energia (140 keV).

TABELA II - Geradores utilizados em Medicina Nuclear

\begin{tabular}{|c|c|c|c|c|c|c|c|}
\hline $\begin{array}{l}\text { Nuclideo } \\
\text { "pai" }\end{array}$ & $\begin{array}{l}\text { nuclídec } \\
\text { "pai" }\end{array}$ & $\begin{array}{l}\text { Reação } \\
\text { nuclear }\end{array}$ & $\begin{array}{l}\text { Nuclideo } \\
\text { "filho" }\end{array}$ & $\begin{array}{l}t_{1 / 2} \text { nuclideo } \\
\text { "filho" } \\
\text { d }\end{array}$ & $\begin{array}{c}\text { Tipo de } \\
\text { decaimento } \\
\text { nuclideo "filho" }\end{array}$ & $\begin{array}{c}\text { Energia } \\
(\mathrm{keV})\end{array}$ & Eluente \\
\hline Mo & $66 \mathrm{~h}$ & Fissão ${ }^{98} \mathrm{Mo}(\mathrm{n}, \mathrm{g})$ & $99 \mathrm{~m} \mathrm{Tc}$ & $6 \mathrm{~h}$ & $\mathrm{Tl}$ & 140 & $\mathrm{NaCl} 0.9 \%$ \\
\hline${ }^{13} \mathrm{Sn}$ & $115 \mathrm{~d}$ & ${ }^{112} \mathrm{Sn}(\mathrm{n}, \mathrm{g})$ & ${ }^{112 \mathrm{~m}} \mathrm{In}$ & $99,5 \mathrm{~min}$ & $\mathrm{Tl}$ & 39 & $\mathrm{HCl}$ \\
\hline${ }^{87} \mathrm{Y}$ & $80 \mathrm{~h}$ & ${ }^{88} \mathrm{Sr}(\mathrm{p}, 2 \mathrm{n})$ & ${ }^{87} m \mathrm{Sr}$ & $2,8 \mathrm{~h}$ & $\mathrm{TI}$ & 388 & $\mathrm{NaHCO}_{3} 0,15 \mathrm{M}$ \\
\hline${ }^{68} \mathrm{Ge}$ & $271 \mathrm{~d}$ & ${ }^{69} \mathrm{Ga}(\mathrm{p}, 2 \mathrm{n})$ & ${ }^{68} \mathrm{Ga}$ & $68 \mathrm{~min}$ & b+ + & 511 & EDTA $0,005 \mathrm{M}$ \\
\hline${ }^{6} \mathrm{Zn}$ & $9,3 \mathrm{~h}$ & ${ }^{63} \mathrm{Cu}(\mathrm{p}, 2 \mathrm{n})$ & ${ }^{62} \mathrm{Cu}$ & $9,7 \mathrm{~min}$ & b+ + & 511 & $\mathrm{HCl} 2 \mathrm{~N}$ \\
\hline${ }^{81} \mathrm{Rb}$ & $4,6 \mathrm{~h}$ & ${ }^{79} \mathrm{Br}(\mathrm{a}, 2 \mathrm{2n})$ & ${ }^{81}=\mathrm{Kr}$ & $13 \mathrm{~s}$ & $\mathrm{TI}$ & 190 & Água ou ar \\
\hline${ }^{82} \mathrm{Sr}$ & $25,5 \mathrm{~d}$ & ${ }^{85} \mathrm{Rb}(\mathrm{p}, 4 \mathrm{n})$ & ${ }^{82} \mathrm{Rb}$ & $75 \mathrm{~s}$ & $b^{+}$ & 511 & $\mathrm{NaCl} 0,9 \%$ \\
\hline
\end{tabular}

Fonte: http://www.scielo.br/pdf/\%0D/rbcf/v42n2/a02v42n2.pdf 
Slide da figura 21: Apresenta-se o cálculo da meia vida do ${ }^{99 \mathrm{~m}} \mathrm{Tc}$. Supondo que uma amostra contém dois gramas de ${ }^{99 \mathrm{~m}} \mathrm{Tc}$ inicialmente, após seis horas a amostra terá um grama de ${ }^{99 \mathrm{~m}} \mathrm{Tc}$, após doze horas terá meio grama, passado dezoito horas sobrarão 25 centésimos de grama e assim por diante. Ao lado do cálculo, um gráfico de barras, pode reforçar o cálculo, com um exemplo de meia vida de oito dias, podendo acrescentar que é uma função exponencial.

Figura 21 - Cálculo da meia-vida do Tecnécio metaestável.

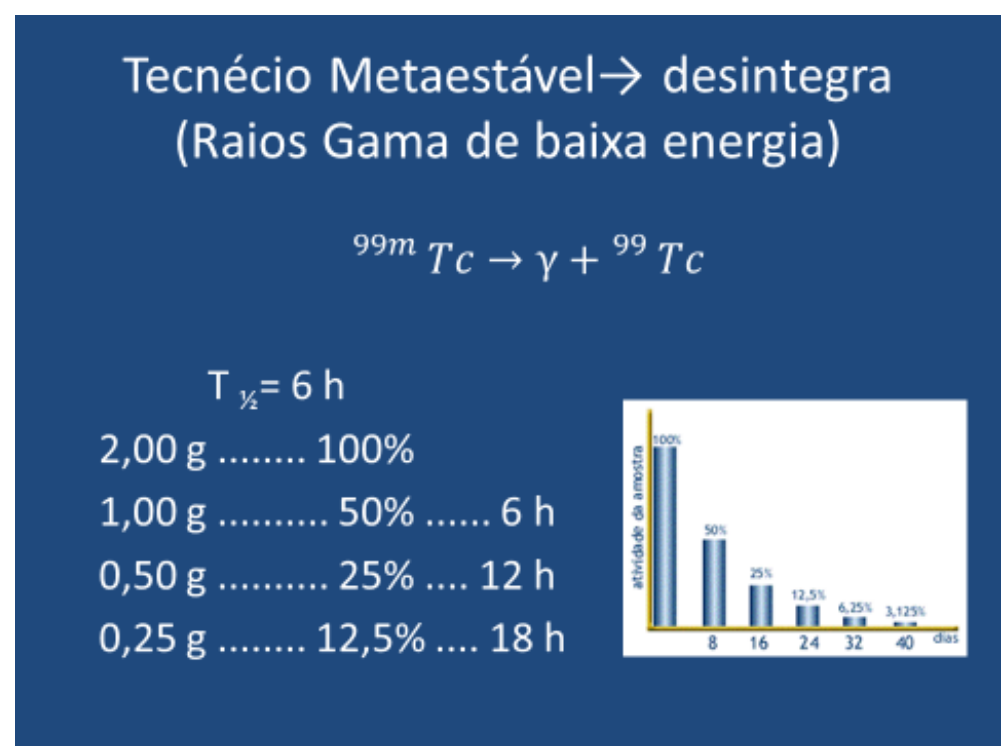

Fonte: Elaborado pela autora e http://www.engquimicasantossp.com.br/2015/02/tempo-demeia-vida.html

\subsubsection{Plano de Segurança nas Termoelétricas tipo Pressurized Water Reator}

Para introduzir o último tópico, sobre a produção de energia elétrica, utilizando EN, pode-se começar discutindo sobre a sociedade tecnológica, que ela depende cada vez mais da eletricidade para obter maior comodidade, o que aumenta a cada ano a demanda da sua produção, porque todos querem celulares de última geração, todos os tipos de eletrodomésticos, os seus próprios aparelhos eletrônicos, televisões, videogames, o que causa impactos ambientais do momento da extração da matéria prima da natureza, durante a produção, transporte até o descarte dos rejeitos de volta na natureza (LOVELOCK, 2010). 
Slide da figura 22: Pode-se constatar a utilização da energia elétrica para a iluminação nas grandes metrópoles, grande parte no hemisfério Norte onde estão localizados os países considerados do primeiro mundo, pode-se questionar a forma que a energia é utilizada, que se rediscuta a ideia da sustentabilidade e que seu consumo seja utilizado de forma inteligente, sem que haja desperdício e quando necessário, de preferência sem ostentação, porque qualquer forma para produzir energia elétrica causa impacto na natureza.

Figura 22 - Quem quer energia? Utilizar energia de forma sustentável.

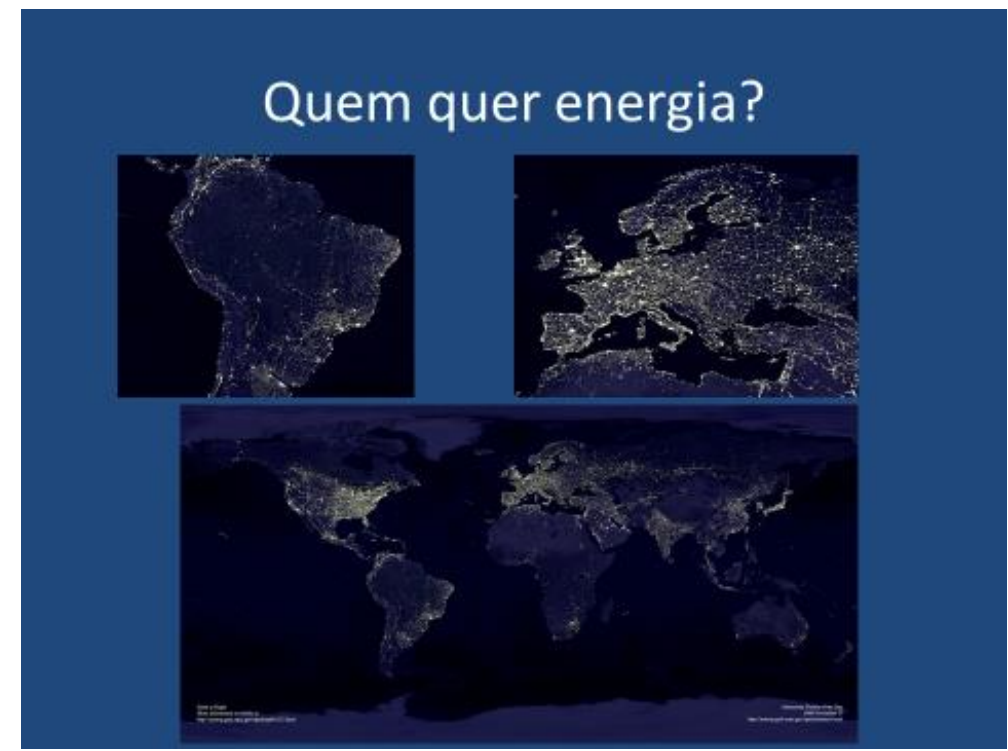

Fonte: https://www.nasa.gov/mission pages/NPP/news/earth-at-night.html

Slide da figura 23: Pode se afirmar que a humanidade causa impactos ambientais e em relação ao aumento da temperatura da atmosfera, mesmo não havendo consenso da comunidade científica, o homem lança grandes quantidades de gases de efeito estufa e poluidoras na atmosfera, principalmente ao se produzir energia elétrica utilizando carvão mineral ou derivados do petróleo, porque lança grandes quantidades de fumaça $(\mathrm{CO})$ e gás carbônico $\left(\mathrm{CO}_{2}\right.$ - gás de efeito estufa). Nas hidrelétricas ao represarem água, grandes áreas verdes são inundadas o que causa a morte da fauna e consequentemente a decomposição desta matéria orgânica emitindo o gás metano $\left(\mathrm{CH}_{4}\right.$ - gás de efeito estufa), além do impacto que causa na fauna do local. Em relação às usinas eólicas, as turbinas impactam a fauna, com o barulho dos rotores. No término da vida útil de cada usina, qualquer que seja a fonte 
utilizada, deve-se estudar a melhor forma de descomissionamento, diminuindo ao máximo o impacto ambiental causado pelo material de descarte.

Figura 23 - Qualquer forma para obter energia elétrica causa algum tipo de impacto ambiental ${ }^{12}$.

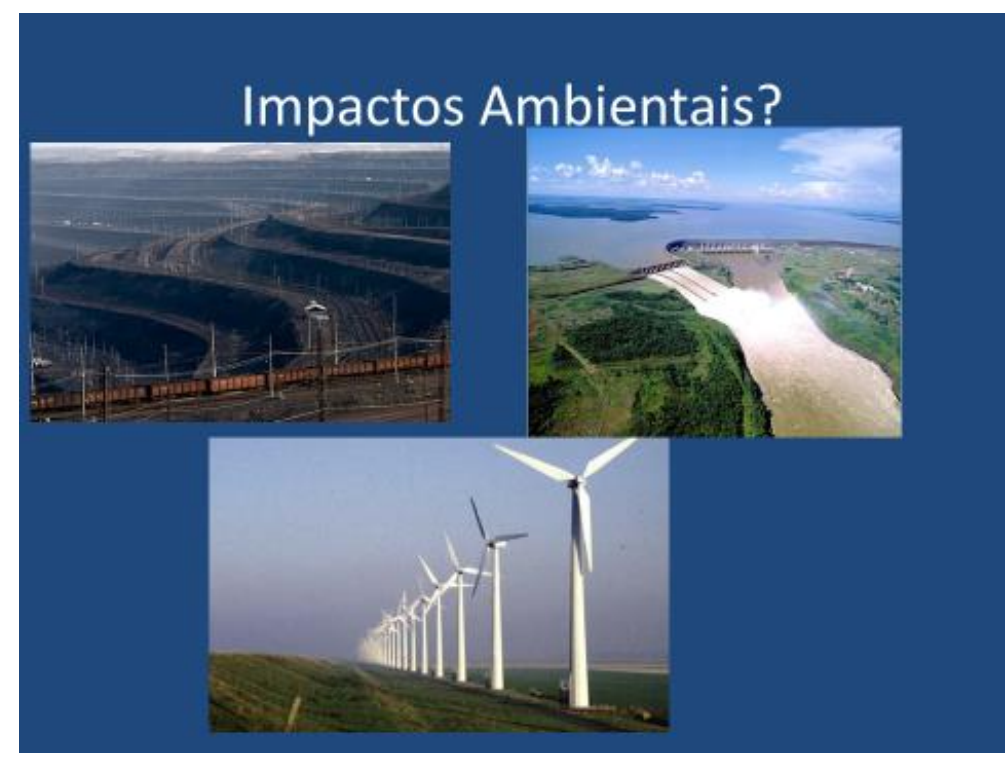

Slide da figura 24: No Brasil em 2015 a matriz energética, para a produção de energia elétrica foi aproximadamente $83 \%$ para a hidrelétrica, seguida pela geração nuclear $(9,76 \%)$, gás natural $(2,75 \%)$, óleo $(2,73 \%)$, carvão $(1,46 \%)$, e as fontes eólica e fotovoltaica (0,20\%). Se somar as fontes renováveis (hídrica, eólica, solar) com a fonte nuclear resulta quase $93 \%$ do total, o que evidencia esta ser uma matriz com muito baixa emissão de gases de efeito estufa $\left(\mathrm{CO}_{2}\right.$, hexafluoreto de enxofre, gases de refrigeração, óxido nitroso e $\left.\mathrm{CH}_{4}\right)\left(\right.$ ELETROBRAS ELETRONUCLEAR ${ }^{1}$, 2015).

\footnotetext{
${ }^{12}$ Fontes: http://mineracionempesquisa.blogspot.com.br/ https://economia.uol.com.br/album/2012/09/26/saiba-como-e-produzido-energia-na-usinahidreletrica-de-itaipu.htm https://www.google.com.br/search?rlz=1C1GGRV enBR751BR751\&biw=1236\&bih=602\&tb $\underline{m=i s c h \& s a=1 \& q=u s i n a+e o l i c a+n a+p r a i a+n a+E u r o p a \& o q=u s i n a+e o l i c a+n a+p r a i a+n a+E u r o p}$ a\&gs I=psyab.3...34493.41507.0.42677.12.11.1.0.0.0.115.1059.8j3.11.0.dummy maps web fallback... $0 \ldots 1.1 .64 . \mathrm{psy}-$ ab..0.0.0...0.HcapVS XpRs\#imgdii=9IWbEamdlBZTHM:\&imgrc=iXvorqP6RcmG5M: http://www.eletronuclear.gov.br/Aempresa/CentralNuclear.aspx
} 
Figura 24 - Matriz energética no Brasil no ano de 2015. As energias hidráulica, eólica, fotovoltaica e nuclear, representam $93 \%$ na geração de energia elétrica ${ }^{13}$.

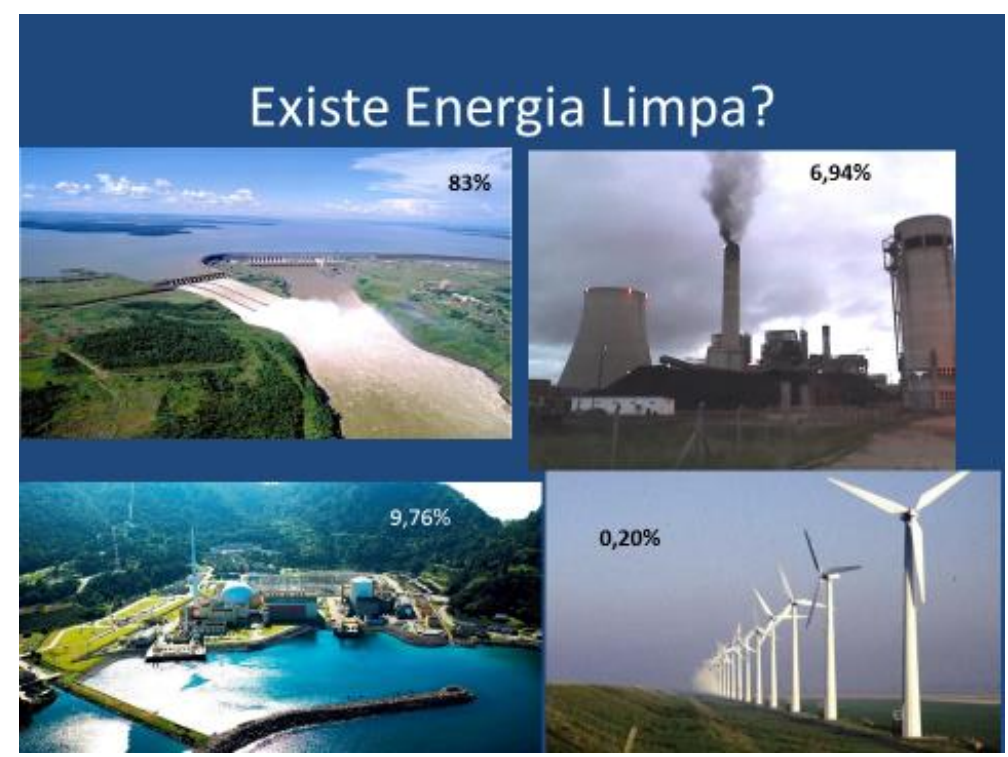

Slide da figura 25: A EN é considerada limpa (BOEMER, 2011), por não emitir nenhum tipo de gás de efeito estufa na produção de energia elétrica.

Figura 25 - Energia Nuclear é Energia Limpa - Na produção de energia elétrica não emite gases de efeito estufa.

Fonte: $\underline{\text { http://www.eletronuclear.gov.br/Aempresa/CentralNuclear.aspx }}$

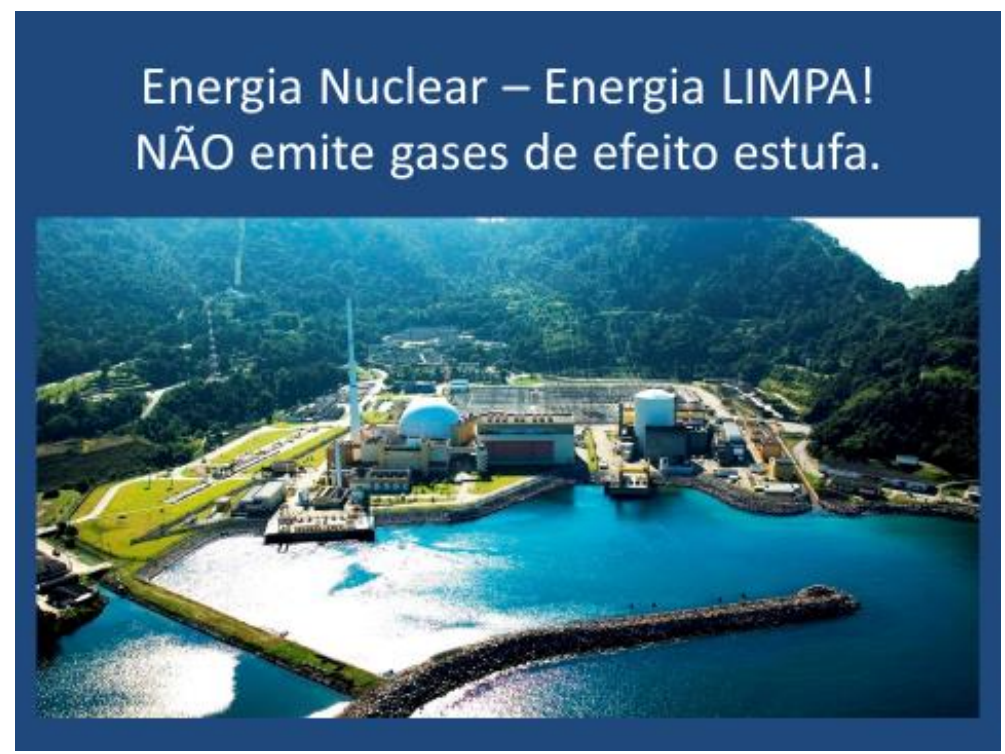

${ }^{13}$ Fontes: https://economia.uol.com.br/album/2012/09/26/saiba-como-e-produzido-energiana-usina-hidreletrica-de-itaipu.htm https://pt.slideshare.net/joaoalfredo50050/avaliao-de-impactos-ambientais http://www.ecodesenvolvimento.org/posts/2014/os-dez-estados-brasileiros-que-maisproduzem?tag=energia 
Slide da figura 26: A Central Nuclear Almirante Álvaro Alberto (CNAAA) está localizada em Cunhambebe, no município de Angra dos Reis, no estado do Rio de Janeiro. O complexo é composto pelas usinas Angra 1, Angra 2 e futuramente Angra 3, opção escolhida devido a vários fatores como: viabilização empresarial e a sua sustentabilidade, maximizando o aproveitamento da infraestrutura necessária para o funcionamento, incluindo os recursos logísticos, técnicos e de mão de obra especializada, comportando o maior número de usinas possíveis no local e perto das cidades urbanas que serão favorecidas pela energia elétrica produzida, reduzindo o custo da transmissão, assim a balança do custo-benefício seja favorável (ELETROBRAS ELETRONUCLEAR ${ }^{2}, 2017$ ).

Figura 26 - Infraestrutura projetada para três usinas nucleares.

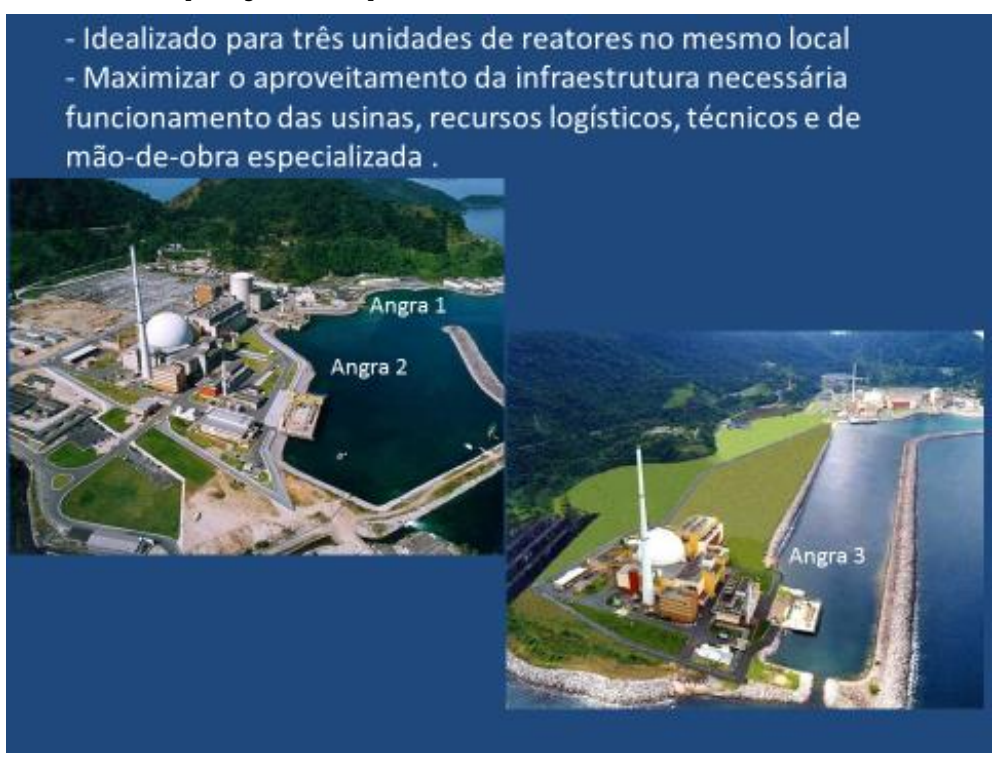

Fonte: $\underline{\text { http://www.eletronuclear.gov.br/Aempresa/CentralNuclear.aspx }}$

Slide da figura 27: Foram considerados também os fatores de aspectos geográficos, meteorológicos, hidrológicos, geológicos, sismológicos e geotécnicos dos sítios, normas estabelecidas CNEN. Pode-se notar que é uma baía protegida em área de baixa densidade populacional, e são analisados todos os possíveis riscos inerentes ao empreendimento, até mesmo os improváveis como terremotos ou a queda de um avião sobre as instalações, mesmo sendo fora da rota de aviões. 
Figura 27 - Fatores naturais protegem a Central Almirante Álvaro Alberto.

$\checkmark$ Estado do Rio de Janeiro:

- próximas dos centros de abastecimento e consumo

- situada em uma baía protegida

- área de baixa densidade populacional

- condições geológicas favoráveis

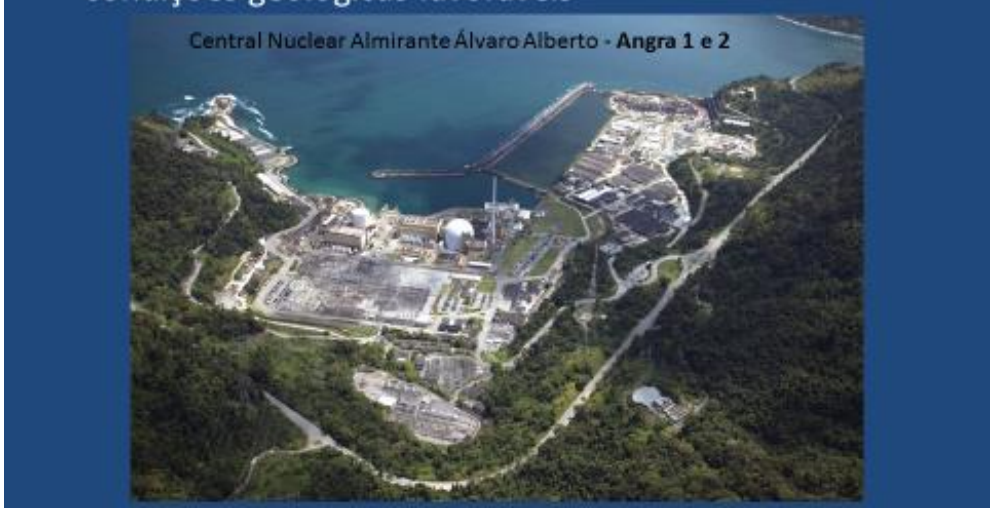

Fonte: http://www.eletronuclear.gov.br/Aempresa/CentralNuclear.aspx

Slide da figura 28: Com a animação, pode se explicar o funcionamento de um Reator Nuclear do tipo Pressurized Water Reator (PWR), reator de água pressurizada, isto é, a água que passa pelo circuito primário, é mantida sob grande pressão para que não entre em ebulição a uma temperatura de $300{ }^{\circ} \mathrm{C}$ (TERREMOTO, 2004). O reator possui um núcleo onde ocorrem as fissões dos átomos de urânio, dentro de varetas, aquecem a água que está num circuito fechado primário (em amarelo). Este circuito primário troca calor com o circuito secundário (em azul claro) movimentando a turbina que está ligada a um gerador elétrico, transformando energia cinética em energia elétrica.

O vapor que está no segundo circuito após girar a turbina, troca calor mais uma vez com um terceiro circuito que possui um condensador (em azul escuro) e depois bombeado de volta. Pode reforçar que os três circuitos são fechados e independentes, o primeiro circuito que tem contato com o núcleo que usina nuclear não sai do vaso de contenção. Além das precauções na produção de energia elétrica, são tomadas outras como o material de fissão, o dióxido de urânio, contido em pastilhas, acondicionadas em varetas feitas por liga de Zircaloy, condição que apenas uma pequena fração dos produtos de fissão escape da estrutura no circuito primário. O vaso do reator e o sistema primário estão protegidos por um vaso de contenção de aço e outro mais externo de concreto que protegem de possíveis impactos externos, até mesmo explosões, e pressões internas do reator. Existem também, se houver alguma anormalidade do núcleo não desejado, um sistema de 
desligamento rápido, com barras de controle absorvedoras de nêutrons acionados pela gravidade sem a necessidade de um sistema elétrico. (ELETROBRAS ELETRONUCLEAR ${ }^{2}$, 2017).

Figura 28- Pressurized Water Reator (PWR) - Plano de Segurança

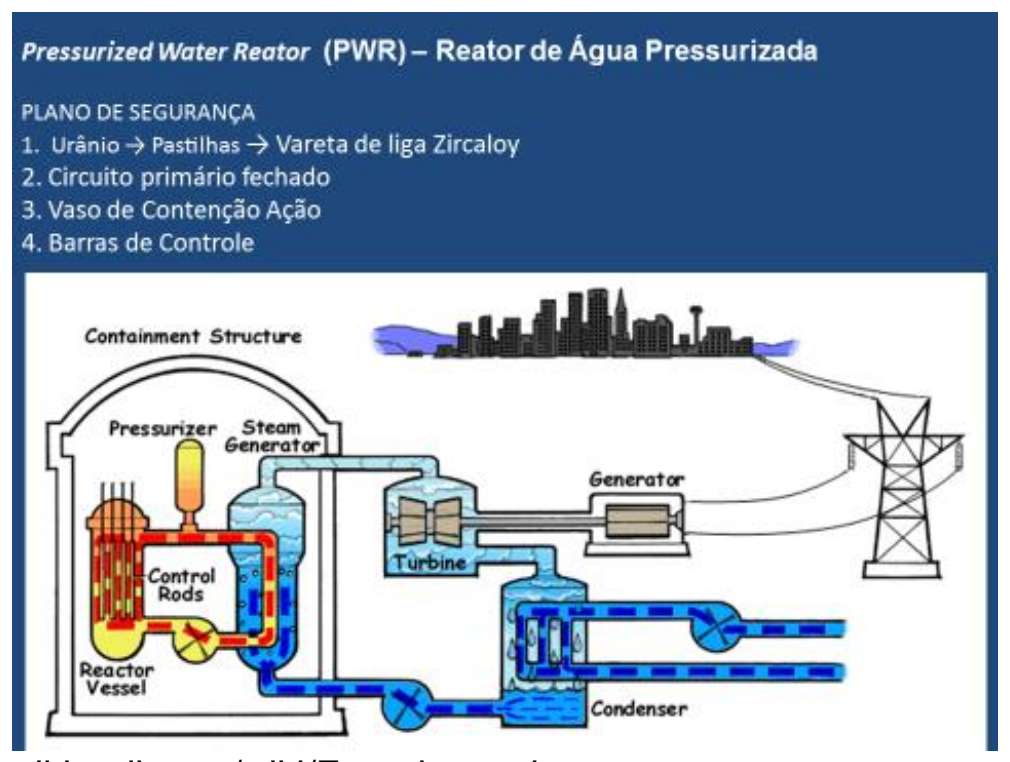

Fonte: https://pt.wikipedia.org/wiki/Energia nuclear

Slide da figura 29: Explica-se de forma sucinta o gerenciamento de resíduos radioativos, que são classificados pela radioatividade de emite como: baixa, material utilizado na operação das usinas como luvas, aventais, que são descontaminados, triturados e prensados e acondicionados em embalagens metálicas que bloqueiam a passagem da radiação; média, como filtros, efluentes líquidos solidificados, que são acondicionados em uma matriz sólida de cimento e mantidos em recipientes de aço apropriados, ambos material de baixa e média atividade é mantido em depósitos no próprio sítio da Central Nuclear Almirante Álvaro Alberto. O Resíduo de alta radioatividade, como elementos combustíveis, ficam armazenados em piscinas especiais, dentro dos prédios de segurança das usinas, porque podem ser depois de reprocessados e reaproveitados no futuro (ELETRONUCLEAR $\left.{ }^{2}, 2017\right)$. 
Figura 29 - Gerenciamento de Resíduos Radioativos.

Fonte:

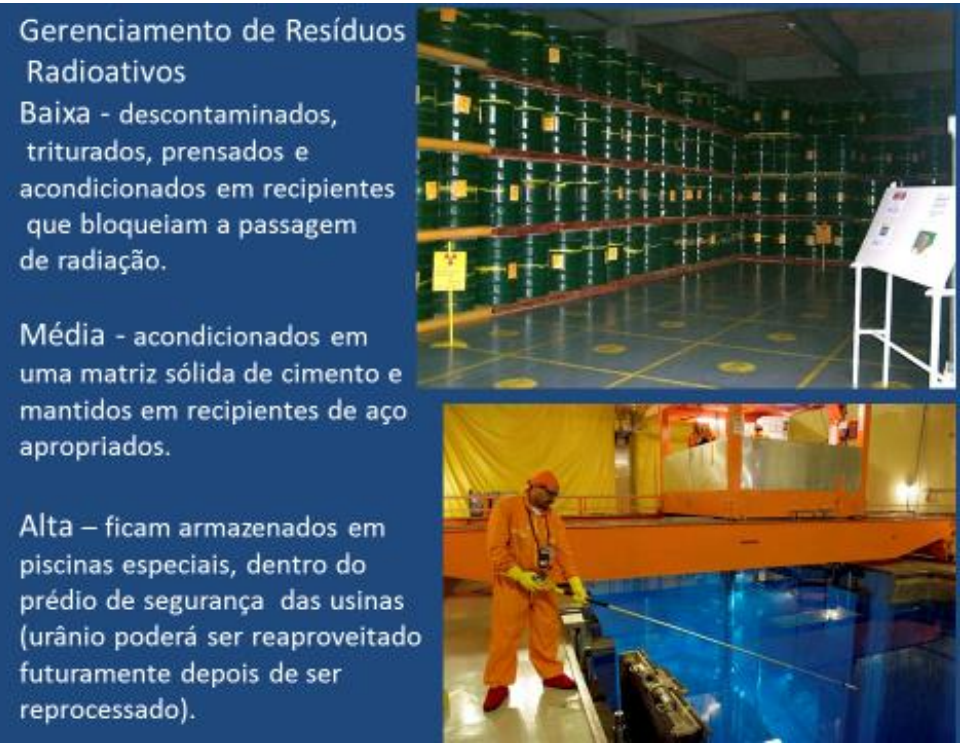

http://www.eletronuclear.gov.br/Saibamais/Gerenciamentoderes\%C3\%ADduos/Res\%C3\%A Dduosradioativos.aspx

Assim termina a palestra agradecendo atenção dispensada.

\subsection{Quarta Etapa - Atividade}

Esta sugestão pode ser utilizada para relembrar alguns itens apresentados na palestra para verificação da aceitação da utilização da TN e consolidar o aprendizado dos itens: energia limpa, forças nucleares, radiação $\alpha, \beta^{-}$e $\gamma$, meia-vida de um material radioativo e diferença entre irradiar e contaminar. Após a realização da atividade individualmente ou em duplas, a correção e a discussão das questões deverão ser feitas, pois o público almeja saber as respostas certas independentemente se houve acerto ou não.

Gabarito da Atividade: 2 A; 3 E; 4 C; 5 B; 6 E e 7 A. 


\section{Atividade}

1. Você é favorável a utilização da Tecnologia Nuclear para:

( ) Medicina - Diagnóstico e Tratamento.

( ) Produção de Energia Elétrica por ser Energia Limpa.

( ) Irradiar alimentos e materiais cirúrgicos.

( ) Todas as atividades citadas acima.

( ) Nenhuma das atividades.

2. Sobre impactos ambientais, o que se refere ao Aquecimento Global, foi constatado que a Terra vem sofrendo o aumento de temperatura, alguns acreditam que seja devido a emissão de gases de efeito estufa como Gás Carbônico, Metano, alguns Aerossóis, de origem antropogênica. A produção de energia elétrica que emite menos gases de efeito estufa é:
(A) Nuclear.
(B) Hidrelétrica.
(C) Carvão Mineral.
(D) Produtos do Petróleo.
(E) Nuclear e Hidrelétrica.

3. O resultado entre as Forças Nucleares pode ser a emissão de:
(A) Raios X e Partículas Nucleares.
(B) Raios X e Gama.
(C) Raios Gama e apenas partícula Alfa.
(D) Raios $X$ e partículas nucleares.
(E) Raios Gama e partículas nucleares.

4. O Tecnécio-99, um radioisótopo muito utilizado em diagnósticos médicos, apresenta meia-vida bastante curta. Ele é produzido a partir do Molibdênio, pela sequência de reações nucleares representadas pelas equações, Tc*representa núcleo em estado de energia maior que o fundamental. As emissões $X$ e $Y$ são, respectivamente:

$$
{ }_{42}^{99} M o \rightarrow{ }_{43}^{99} T c^{*}+X \quad \text { e } \quad{ }_{43}^{99} T c^{*} \rightarrow{ }_{43}^{99} T c+Y
$$
(A) Partícula Alfa e Partícula Alfa.
(D) Partícula Alfa e Radiação Gama.
(B) Partícula Beta e partícula Alfa.
(E) Radiação Gama e Radiação Gama.
(C) Partícula Beta e Radiação Gama.

5. $\mathrm{O}{ }^{201} \mathrm{TI}$ é um isótopo radioativo usado na forma de $\mathrm{TICl}_{3}$ (cloreto de tálio) para diagnóstico do funcionamento do coração. Sua meia-vida é de $73 \mathrm{~h}(\cong 3$ dias). Certo hospital possui 20 gramas deste isótopo. Sua massa, em gramas, após 9 dias, será igual a:
(A) 1,25
(B) 2,5
(C) 5,0
(D) 7,5
(E) 10,0 
6. O acidente com o Césio-137, em Goiânia, no dia 13 de setembro de 1987, foi o maior acidente radioativo do Brasil e o maior do mundo ocorrido em área urbana. $\mathrm{A}$ cápsula de Cloreto de Césio ( $\mathrm{CsCl}$ ) que fazia parte de um equipamento hospitalar usado para radioterapia que utilizava o Césio-137 para irradiação de tumores ou de materiais sanguíneos. Nessa cápsula, havia aproximadamente 19 gramas do $\mathrm{CsCl}$ de meia-vida igual a 30 anos, um pó branco parecido com o sal de cozinha, mas que, no escuro, brilha com uma coloração azul. Admita que a massa total de $\mathrm{CsCl}$, contida na cápsula, tenha sido recuperada durante os trabalhos de descontaminação e armazenada no depósito de rejeitos radioativos do acidente, na cidade de Abadia de Goiás. Dessa forma, o tempo necessário para que restem $6,25 \%$ da quantidade de $\mathrm{CsCl}$ contida na cápsula, e a massa de cloreto de $\mathrm{CsCl}$ presente no rejeito radioativo, após sessenta anos do acidente, são, respectivamente:
(A) 150 anos e $2,37 \mathrm{~g}$.
(D) 120 anos e $9,50 \mathrm{~g}$.
(B) 120 anos e 6,25 g.
(E) 120 anos e 4,75 g.
(C) 150 anos e 9,50 g.

7. Assinale a alternativa ERRADA.

(A) $\mathrm{O}$ aparelho de raios $\mathrm{X}$ e o de radioterapia possuem material radioativo.

(B) $\mathrm{O}$ aparelho de radioterapia emite radiação de partículas e eletromagnética.

(C) Quando uma pessoa está na praia "tomando um Sol", ela é irradiada pela radiação solar.

(D) $\mathrm{O}$ aparelho de raios $\mathrm{X}$ não emite radiação atômica quando desligado.

(E) O aparelho de radioterapia é utilizado para tratamentos de pacientes com câncer. 


\subsection{Quinta Etapa - Interação no Espaço da Tecnologia Nuclear (ETN)}

Se um grupo tiver interesse, pode-se agendar uma visita para o Espaço da Tecnologia Nuclear, local permanente, no IPEN situado no campus da Universidade de São Paulo, onde se apresenta algumas aplicações da TN na medicina, na indústria, na pesquisa e na geração de energia elétrica. O espaço é composto por Banners informativos sobre: o Nuclespaço; Do que tudo é feito; Radiação Natural; Tipos de Radiação; Câmaras de Nuvens; Marcos históricos; Radiação $\rightarrow$ Tecnologia Modificada; Carreiras na área nuclear; Aplicações da Energia Nuclear e Fontes de Energia. Em relação aos balcões de exposição, segue uma sugestão de roteiro:

\subsubsection{Maquete do Vaso do Reator Nuclear}

$\mathrm{O}$ vaso do reator, figura $30 \mathrm{~A}$, faz parte do circuito primário do PWR que possui dutos de entrada e saída para água, que é o líquido refrigerante em temperaturas da ordem $275^{\circ} \mathrm{C}$ sob pressões da ordem de $15 \mathrm{MPa}$, passe pelos elementos combustível. Neste circuito primário, é gerado o calor necessário para transformação da energia nuclear, para a térmica, depois cinética e enfim na elétrica. Nesta bancada também possui 6 amostras das etapas da produção da pastilha de dióxido de urânio $\left(\mathrm{UO}_{2}\right)$, figura $30 \mathrm{~B}$. A Indústria Nuclear do Brasil, na unidade de Caetité- Bahia, realiza a exploração do minério que contém urânio, produção de concentrado de $\mathrm{U}_{3} \mathrm{O}_{8}$ (yellowcake). O yellowcake é depois convertido em $\mathrm{UF}_{6}$, feito pela empresa Areva, na França. A próxima etapa é o enriquecimento isotópico, aumentar a concentração do isotópo ${ }^{235} \mathrm{U}$, feita pelo consórcio Urenco (Alemanha, Holanda, Grã-Bretanha) utilizando a tecnologia da ultracentrifugação, etapa que o Brasil domina a tecnologia e o projeto atual prevê a implantação da unidade da Fábrica de Combustível Nuclear, em Resende, no estado do Rio de Janeiro, com a capacidade de abastecer $100 \%$ as necessidades de Angra 1 e $20 \%$ de Angra 2. Após o enriquecimento é feita a reconversão do $U F_{6}$ transformando em pó de dióxido de urânio $\left(\mathrm{UO}_{2}\right)$, a fabricação de pastilhas de $\mathrm{UO}_{2}$, montagem da vareta e do elemento combustível, isso realizado em Resende (ELETROBRAS ELETRONUCLEAR ${ }^{1}$, 2017). 
Figuras 30 A - Maquete do Vaso do Reator Nuclear. 30 B - Vareta do elemento combustível e amostras do ciclo do combustível do Urânio.

(30A)

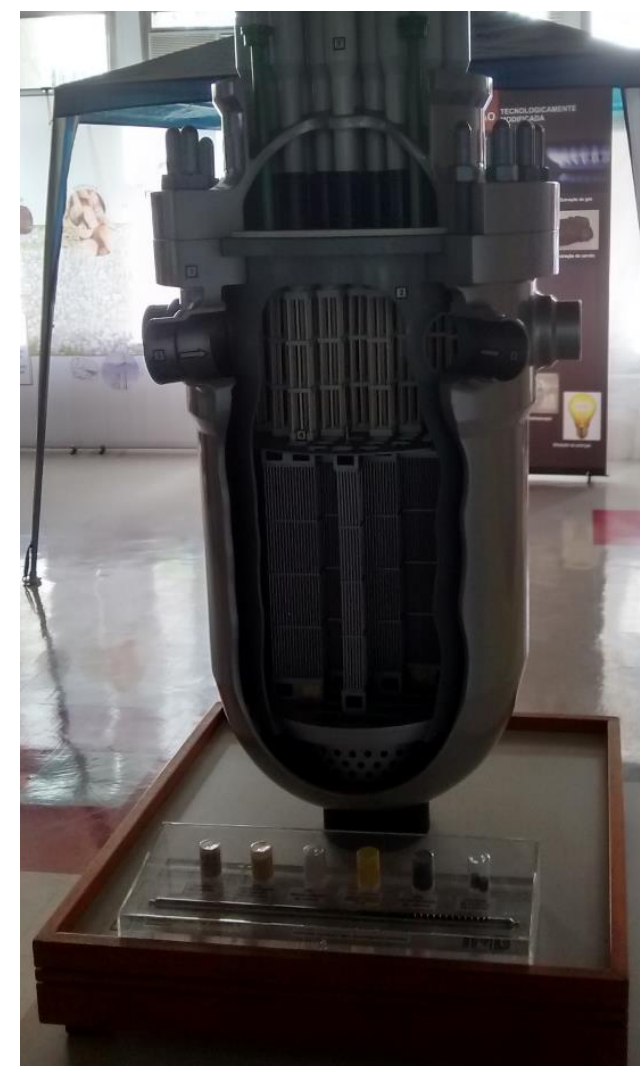

Fonte: Fotos da autora.
(30B)

\subsubsection{Elemento Combustível}

Os elementos combustíveis, figura 31, são instalados, dentro do vaso do reator, em conjuntos mecânicos que compõe o núcleo do reator nuclear, cada elemento de combustível possui um conjunto de varetas de uma liga metálica especial, o zircaloy, com as pastilhas de $\mathrm{UO}_{2}$.

Figura 31 - Elemento Combustível.

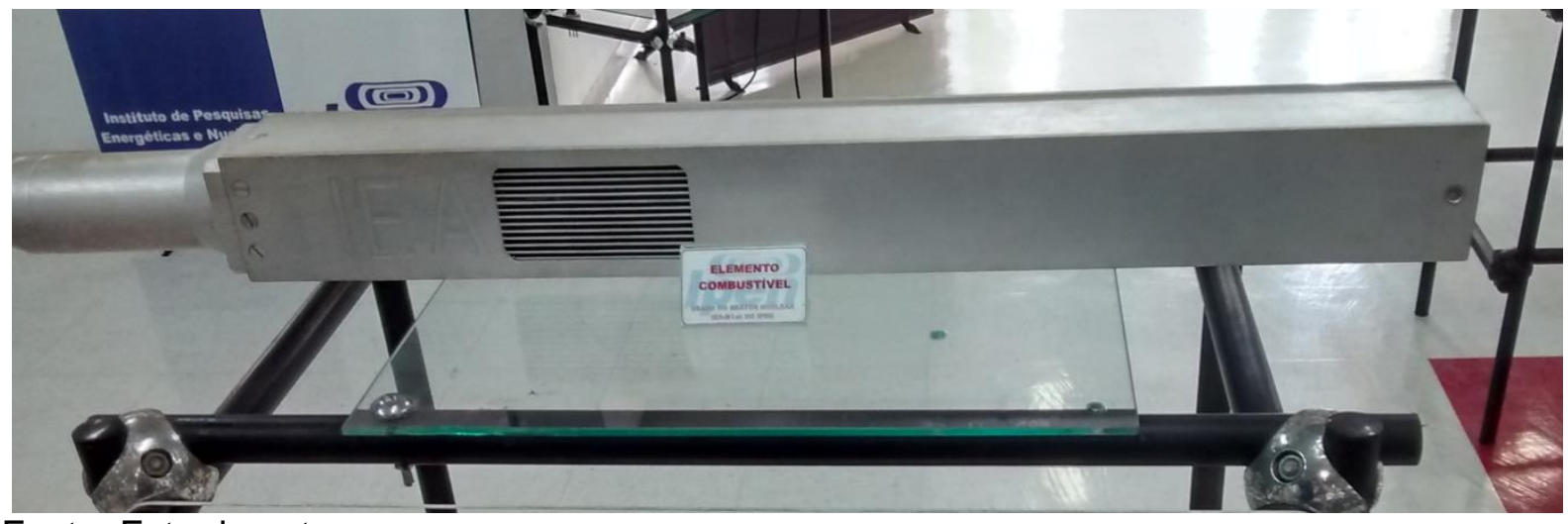

Fonte: Foto da autora. 


\subsubsection{Gerador do Radiofármaco ${ }^{99 \mathrm{~m}} \mathrm{Tc}$}

Um gerador permite obter um radionuclídeo de meia-vida curto, a partir de um radionuclídeo de meia-vida longo. O gerador exposto no ETN, figura 32, é de Tecnécio-99 metaestável $\left({ }^{99 \mathrm{~m}} \mathrm{Tc}\right)$ de meia-vida 6 horas que é obtido por decaimento do "pai" Molibdênio-99 que tem meia-vida de 66 horas. O gerador foi desenvolvido para proteger principalmente os profissionais que trabalham com os radiofármacos, estes seguindo as normas estabelecidas, minimizam o tempo de exposição e evitam a contaminação, inclusive o profissional que administra o radionuclídeo no paciente, por ser simples e de rápido manejo (SANTOS-OLIVEIRA, 2010).

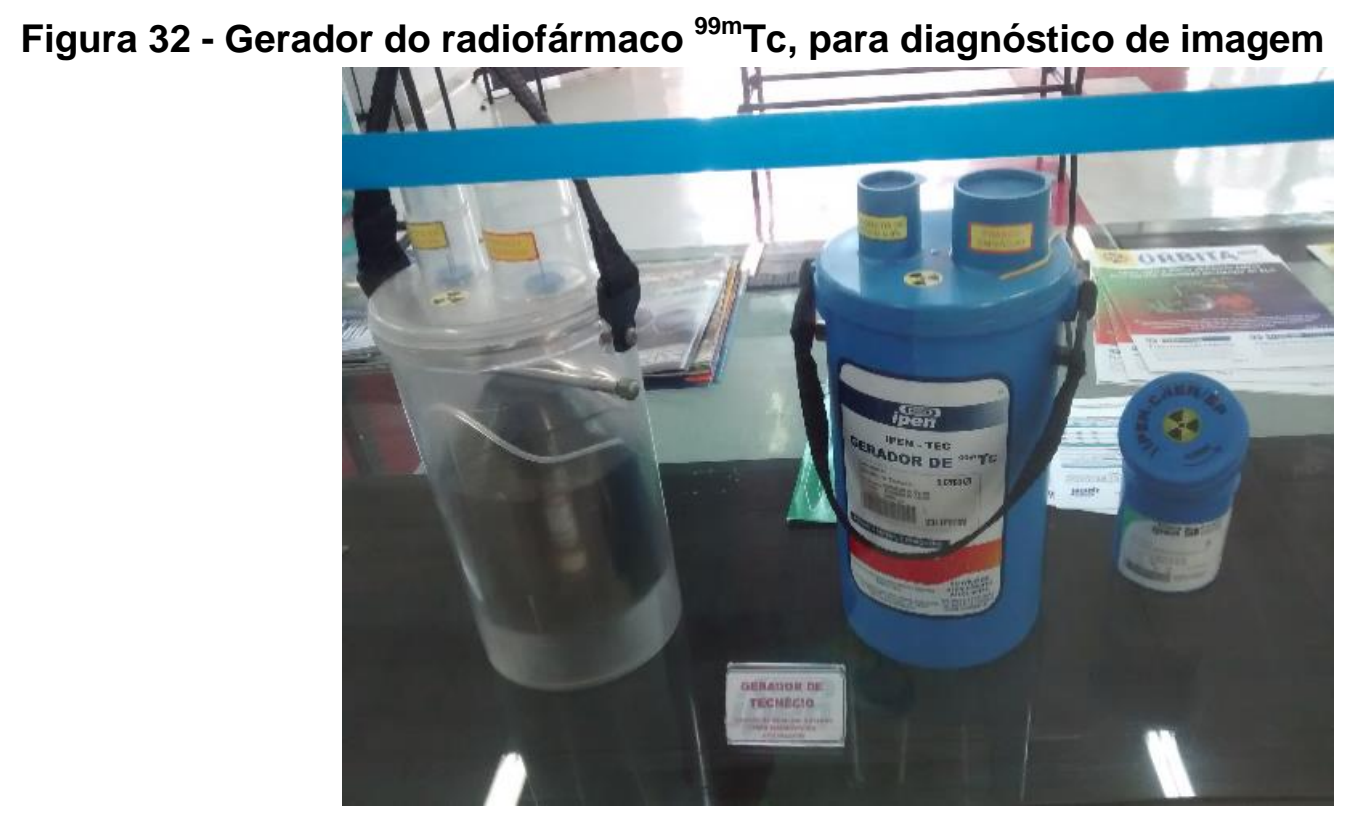

Fonte: Foto da autora.

\subsubsection{Aplicação da Irradiação}

A radiação ionizante é utilizada também para a modificação de polímeros, para esterilização de materiais cirúrgicos, médicos e farmacêuticos, figuras 33 A e 33 B. Ao incidir esta radiação sob um material polimérico ocorrem dois processos simultaneamente: (a) a formação de ligações químicas entre as cadeias moleculares; (b) a destruição da estrutura do polímero. Sempre um processo prevalece sobre o outro e dependendo do que se quer obter como produto final, se estuda a dose e o tipo da radiação, visando a melhoria do material em relação as propriedades térmicas, mecânicas e químicas, de materiais como fios e cabos 
elétricos (PINO e GIOVEDI, 2005). Na medicina, se produz um polímero, Hidrogel, utilizados em pacientes com queimaduras e em diferentes tipos de lesões de pele, diminuindo o tempo de cicatrização e a dor. Na alimentação se irradia certos grãos, legumes ou frutas, para aumentar o tempo do produto para a comercialização, para controlar os parasitas e inibir o brotamento, sempre adequando para cada alimento a dose para manter o sabor, cor, consistência e odor (CARDOSO, 2015). Na indústria farmacêutica, médica e cirúrgica, há a necessidade de microorganismos nocivos à saúde, algumas vantagens de irradiar, que o equipamento ao ser irradiado pode já estar embalado pois não há a produção de energia térmica.

Figuras 33 A e 33 B - Produtos irradiados.

(33A)

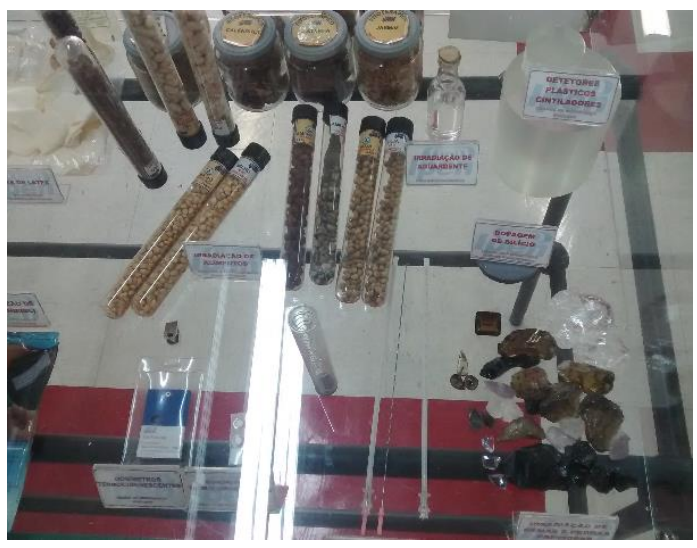

(33B)

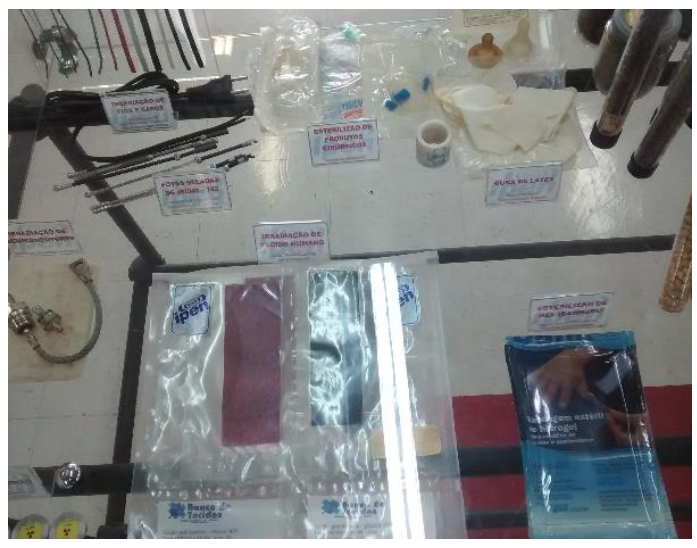

Fonte: Fotos da autora.

\subsubsection{Ampola de Raios $X$}

A ampola de raios $X$, figuras 34 A e 34 B, não possui nenhum material radioativo. Ao ser ligado a uma tensão elétrica produz ondas eletromagnéticas na eletrosfera do átomo, por esta razão é energia atômica. 
Figuras 34 A e 34 B - Ampola de raios $X$.

(34 A)

(34 B)
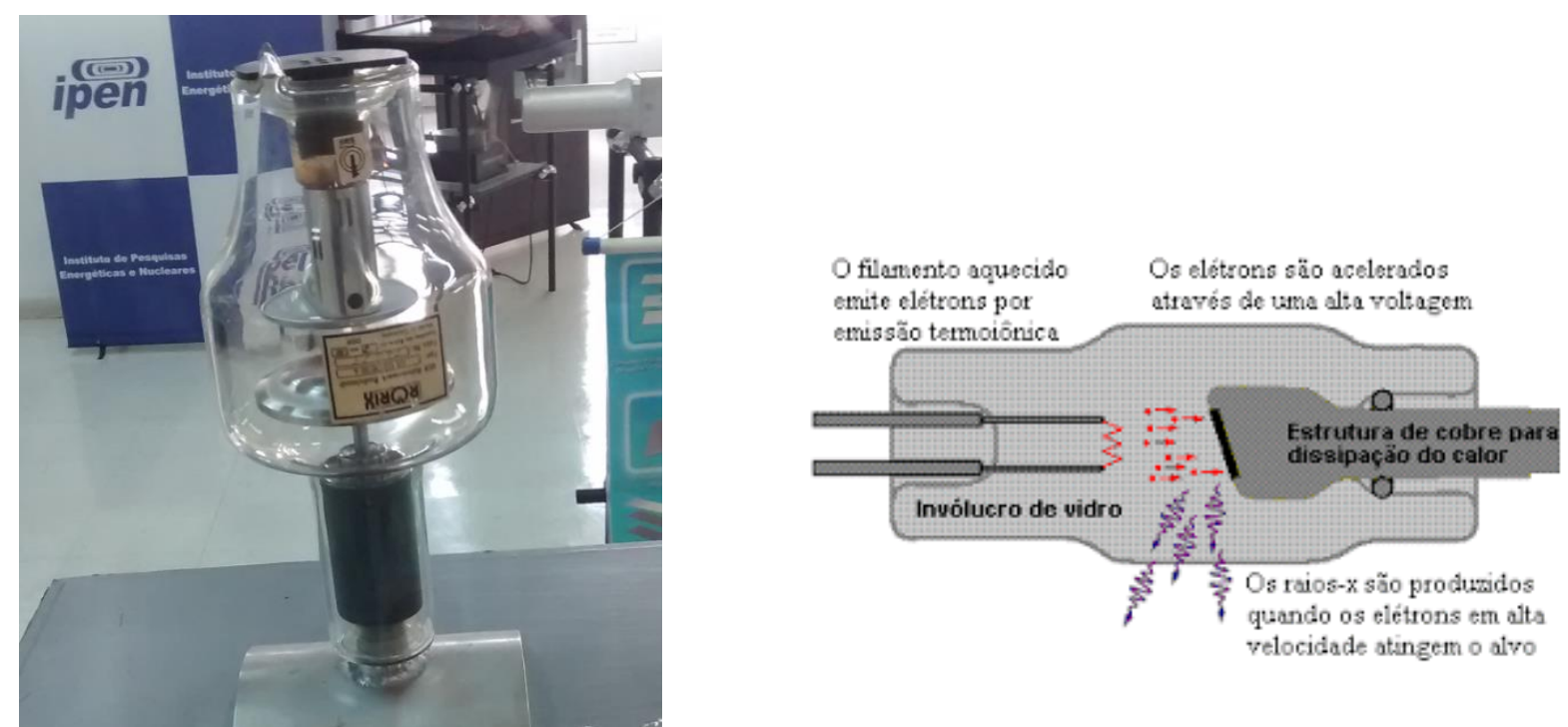

Fonte: Foto da autora e http://leonardoflor.blogspot.com.br/2012/03/proeja.html

\subsubsection{Câmara de Nuvens tipo Difusão}

Diffusion Cloud Chamber (Câmara de nuvens por difusão), figura 35 A, é um detector onde pode-se observar os rastros deixados por partículas energéticas como: Alfa, Beta (de baixa energia), raios cósmicos, ao se propagarem dentro da câmara, porque a partícula energética ao passar por uma molécula de álcool, pode arrancar um ou mais elétrons da sua eletrosfera, ionizando-a. Esses íons atraem moléculas de água, condensando-as, formando gotículas de água que espalham a luz, podendo desta maneira visualizar o caminho que a partícula difundiu, como se pode observar na figura 35 B (PHYSICS ENTERPRISES, 2017). 
Figuras 35 A - Câmara de Nuvens tipo Difusão e 35 B - Visualização dos rastros deixados por partículas energéticas de origem em um material radioativo no centro.

(35 A)

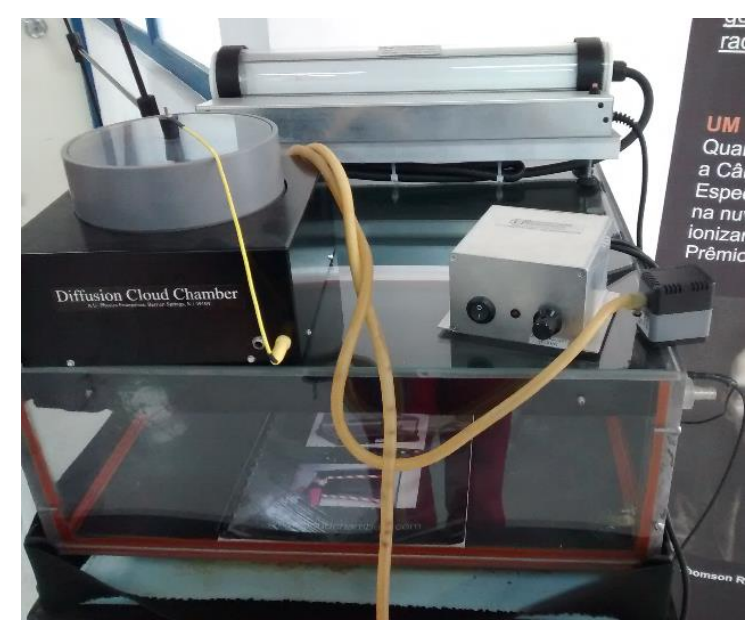

Fontes: Foto da autora e
(35 B)

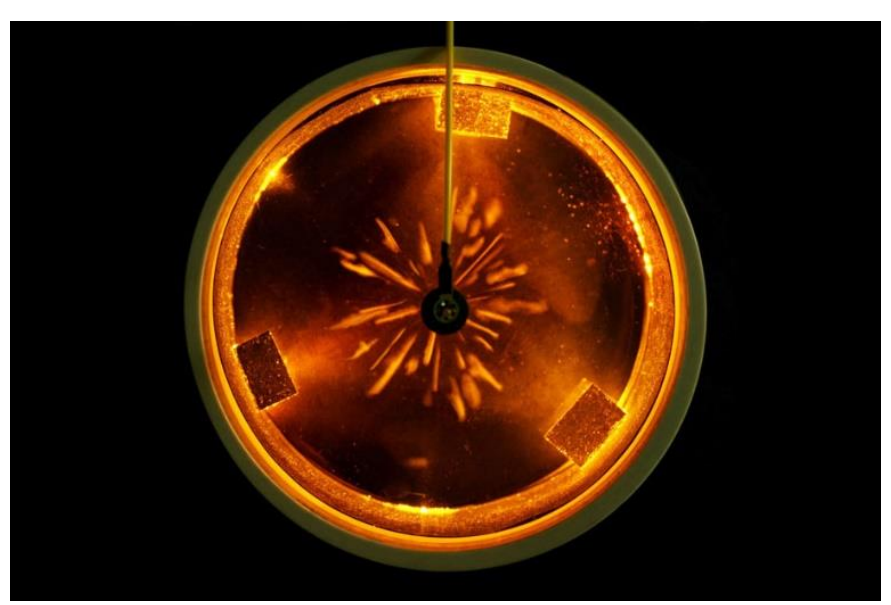

https://www.andrews.edu/services/physicsenterprises/products/diff cloud cham.html

\subsubsection{Detectores de Radiação}

Os detectores de radiação podem ser considerados um transdutor, porque transforma energia de radiação em outro tipo de informação como um sinal elétrico ou de luz e dependendo da informação que se deseja obter, pode se utilizar um aparelho que informe o número de contagens ou energia da radiação detectada ou outro que informe a dose absorvida ao longo de um período, Figuras 36 A e.36 B (IAEA,2017).

Figuras 36 A - Detectores de radiação e 36 B - Detector com interatividade. (36 A)

(36 B)
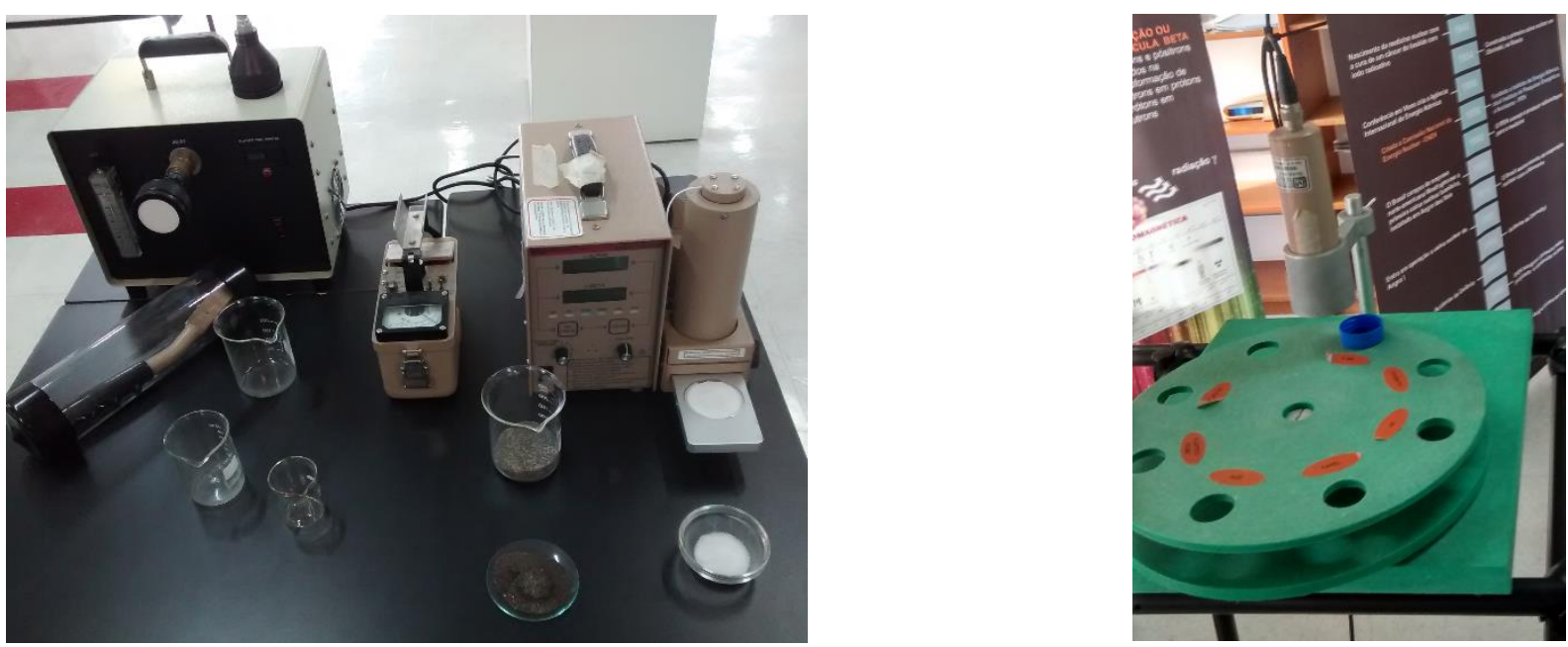

Fonte: Fotos da autora. 


\section{CONCLUSÕES}

Este trabalho apresentou uma Proposta de uma Metodologia para a Divulgação da Tecnologia Nuclear que tem como premissa a comunicação e não somente a informação (ZARUR, 2013) sempre buscando estabelecer o diálogo entre as partes para ressaltar a importância das atividades de Pesquisa, Desenvolvimento, Inovação e a Qualidade dos produtos ofertados por instituições brasileiras, como o IPEN.

Por apresentar um tema que sofre preconceito e causa medo esta metodologia foi composta por ferramentas pedagógicas na busca da interação entre o público e a universidade, para despertar a curiosidade, em um ambiente de confiança do começo ao fim da apresentação, promovendo e divulgando os benefícios da utilização da TEN.

A proposta da metodologia é composta por cinco etapas distintas:

$\checkmark$ Primeira etapa: Questionário Inicial - submetido ao público para que possam, em grupos pequenos, expressar as suas opiniões sem maiores elaborações, possibilitando as manifestações espontâneas dos preconceitos, contextualizando e mantendo-o na zona de conforto.

$\checkmark$ Segunda etapa: Vídeo da reportagem - apresentação relevante para estabelecer a comunicação utilizando a linguagem que forma o senso comum, despertando o interesse e a curiosidade pelo tema, na zona de conforto do público.

$\checkmark$ Terceira etapa: Palestra Elucidativa - para se abordar temas específicos: Inicia-se com a discussão das causas do acidente com o aparelho de radioterapia apresentado no vídeo, enfatizando a sua importância no tratamento para pacientes com câncer; radioatividade (estrutura nuclear; forças nucleares; emissão alfa, beta negativo e gama); sua utilização na medicina (radiofármacos); a segurança para a produção de energia elétrica e ênfase por ser considerada como energia limpa por não emitir gases de efeito estufa.

Nesta etapa utiliza-se de uma linguagem acessível para explicar conceitos de física e química, explorando o entendimento pelo visual com: equações e exemplos que 
vão do mais simples ao se quer chegar; figuras pitorescas; textos curtos; curiosidades históricas: do casal Curie, Röntgen e produtos radioativos comercializados nos anos 30; e animação do funcionamento da usina PWR para enfatizar a segurança no seu funcionamento.

$\checkmark$ Quarta etapa: Atividade - com questões múltiplas escolhas, pode-se verificar mudanças em relação à percepção anterior e revisa conteúdos abordados na palestra como: na produção de energia elétrica, não emite gases de efeito estufa; radiação nuclear é o resultado do desequilíbrio entre as forças nucleares; emissão de radiação alfa, beta negativo e gama; meia vida de um material radioativo; diferença entre irradiar e contaminar. Enfatizando a importância de realizar a correção/discussão dos itens mencionados.

$\checkmark$ Quinta etapa: Interação no ETN - a visita ao espaço contribui demais na solidificação do entendimento, porque o público pode interagir com os produtos e elementos diretamente ligados a TN.

A colaboração dos professores para o desenvolvimento da pesquisa foi relevante porque, com os dados obtidos dos questionários pode-se tirar, acrescentar e/ou manter itens na palestra elucidativa; confirmar a escolha do vídeo; constatar a necessidade de rever os itens abordados com uma atividade desafiadora, para que se absorva o conteúdo apresentado dando condições para que a pessoa possa futuramente utilizar argumentos fundamentados.

O roteiro para interação no ETN fornece dados dos materiais expostos e reforça o aprendizado adquirido, observando no espaço elementos mencionados na palestra elucidativa.

Uma maior aceitação da TN somente virá com o esclarecimento da população e como, por diferentes aspectos, o uso comercial das mídias é inacessível para órgãos da administração direta do Governo Federal, resta participar da mudança de opinião pela educação (AQUINO, 2011), em um ambiente onde o profissional do ensino seja respeitado, pelo seu entendimento prévio, para que a TN não seja rejeitada e dizimada pela sociedade que dela se beneficia. 


\section{TRABALHO FUTURO}

Há a necessidade de se estudar outras metodologias para a divulgação do conhecimento científico e para as suas adaptações às recorrentes mudanças sociais dos últimos tempos, bem como para acertar a dose a ser repassada para o público, para que a quantidade e a qualidade do conhecimento resultantes dos encontros planejados agucem cada vez mais a curiosidade e o aprendizado seja definitivamente incorporado por todos os participantes (MENEZES, 2016).

O trabalho para divulgar conhecimento científico e incentivar os discentes às profissões da área deve ser contínuo nos ambientes escolares, aproximando as comunidades ao universo universitário, o que beneficia muito a sociedade ao capacitar o público para argumentos fundamentados. 


\section{REFERÊNCIAS BIBLIOGRÁFICAS}

ALMEIDA, Renata Araujo. Um estudo simplificado sobre a percepção pública na área nuclear: sugestões para campanhas educativas para diferentes segmentos da sociedade. Dissertação de Mestrado - Instituto de Engenharia Nuclear da Comissão Nacional de Energia Nuclear. Rio de Janeiro 2011.

AQUINO, A. R., Ciência, Tecnologia e Jornalismo, em: MEDINA, C., Ciências e Sociedade: Mediações Jornalisticas - Novo Pacto da Ciência 8, Estação Ciência USP - São Paulo, 2005.

AQUINO, A. R. Qualidade de Vida, Energia e Sustentabilidade: um desafio para as engenharias. Revista: Qualimetria v. 236, p.72-73, 2011.

ARAUJO, Elaine Bortoleti de. A utilização do elemento Tecnécio-99m no diagnóstico de Patologias e Disfunções dos Seres Vivos. Cadernos temáticos de química na nova escola. No 06 - Julho 2005. Disponível em: <http://qnesc.sbq.org.br/online/cadernos/06/a08.pdf> Acesso em: Abr.2017.

BENEVIDES, Maria Victoria de Mesquita. Educação para a democracia. Lua Nova, São Paulo, n. 38, p. 223-237, Dez. 1996 . Disponível em: < http://dx.doi.org/10.1590/S0102-64451996000200011> Acesso: Nov. 2017.

BOEMER, Verônica Araujo. Estudo comparado das percepções de risco nuclear e ambiental. Dissertação de mestrado - Instituto de Pesquisas Energéticas e Nucleares - São Paulo, 2011.

CAPRA, Fritjof. O Tao da Física - Um paralelo entre a Física Moderna e o Misticismo Oriental. São Paulo: Editora Cultrix, 1983.

CARDOSO, Eliezer de Moura. Apostila educativa - Aplicações da Energia Nuclear - 3.ed. Rio de Janeiro. Disponível:

$<$ http://www.cnen.gov.br/images/cnen/documentos/educativo/aplicacoes-da-energianuclear.pdf> Acesso em: Abr.2015.

CARVALHO, Regina Pinto de. Temas Atuais de Física: Micro-ondas. Sociedade Brasileira de Física. 1ª ed. São Paulo: Livraria da Física, 2005. 
CÉSIO137, Linha Direta Justiça. Exibido pela Rede Globo em 09/08/2007Disponível em: <https://www.youtube.com/watch?v=MfshO3PvlYs> Acesso em Dez.2016.

CHAUI, Marilena. "O mito da caverna." (2003).

Disponível em: <http://asmayr.pro.br/arquivos/ldeologia/O_mito_da_caverna.pdf> Acesso: Nov.2016.

CNEN, Normas. Disponível: <http://www.cnen.gov.br/normas-tecnicas> Acesso em: maio 2015.

CORTELLA, Mario Sergio. Não nascemos prontos! Provocações Filosóficas. Petrópolis, RJ: Vozes, 2011.

DOS SANTOS, Wildson Luiz Pereira. Contextualização no ensino de ciências por meio de temas CTS em uma perspectiva crítica. Ciência \& Ensino (ISSN 19808631), $\quad$ v. $\quad 1, \quad 2008 . \quad$ Disponível $\quad$ em: file:///C:/Users/Fernando/Desktop/wellington\%20contextualiza.pdf Acesso: Nov, 2017.

ELETROBRAS. Inventário de Emissões de Gases de Efeito Estufa. Ano base 2015/ Junho 2016. Disponível: <http://eletrobras.com/pt/MeioAmbiente/Inventariode-Emissoes-de-Gases-de-Efeito-Estufa-das-Empresas-Eletrobras-2015.pdf> Acesso em: jun.2017.

ELETROBRAS ELETRONUCLEAR. Temas Gerais - Combustível. Disponível em: $<$ http://www.eletronuclear.gov.br/Saibamais/Perguntasfrequentes/Temasgeraiscomb ust\%C3\%ADvel.aspx> Acesso em: fev.2015.

ELETROBRAS ELETRONUCLEAR. Critérios de segurança adotados para as usinas nucleares Angra 1, Angra 2 e Angra 3. (10/05/2011). Disponível em:

<http://www.eletronuclear.gov.br/LinkClick.aspx?fileticket=Du9hc2tTMpk\%3D\&tabid= 117> Acesso: jun.2017.

ELETRONUCLEAR ${ }^{1}$. Concursos Públicos. Disponível em: <http://www.eletronuclear.gov.br/Aempresa/ConcursoPuacuteblico.aspx> Acesso: maio 2017.

ELETRONUCLEAR ${ }^{2}$. Gerenciamento de resíduos radioativos. Disponível em: <http://www.eletronuclear.gov.br/Saibamais/Gerenciamentoderes\%C3\%ADduos/Res \%C3\%ADduosradioativos.aspx> Acesso: jun.2017. 
FINI, Maria Inês (Coordenadora). Proposta Curricular do Estado de São Paulo: Física (Ensino Médio). Secretaria da educação - São Paulo, 2008.

Disponível em:

<http://www.rizomas.net/images/stories/artigos/Prop_FIS_COMP_red_md_20_03.pd $\mathrm{f}>$ Acesso: jun.2015.

FISCHER, Rosa Maria Bueno. Experiência jovem numa sociedade individualizada: Mídia e aprendizado do público. Rio Grande do Sul: UFRGS, 2004. https://www.researchgate.net/publication/268406936_EXPERIENCIA_JOVEM_NUM $<$ A_SOCIEDADE_INDIVIDUALIZADA_MIDIA_E_APRENDIZADO_DO_PUBLICO> Acesso: set.2015.

FREIRE, Paulo. Pedagogia da autonomia: saberes necessários à pratica educativa/ Paulo Freire - 53 a ed - Rio de Janeiro: Paz e Terra, 2016.

GAUDENCIO, Paulo. Mudar e Vencer: como as mudanças podem beneficiar pessoas e empresas. São Paulo: Editora Palavras e Gestos, 2007.

GLEISER, Marcelo. Criação Imperfeita - 4a edição - Rio de Janeiro: Record, 2010.

GOMES, Paulo de Tarso Vida. Dissertação de Doutorado: Contribuições para a melhoria das metodologias de avaliação de choque térmico pressurizado em vasos de pressão de reatores PWR. São Paulo: IPEN, 2005. Disponível em: <http://www.iaea.org/inis/collection/NCLCollectionStore/_Public/40/096/40096429.pd f> Acesso em: out.2015.

GOLEMAN, Daniel. Inteligência Emocional: e teoria revolucionária que define o que é ser inteligente - $2^{\mathrm{a}}$ ed - Rio de Janeiro: Objetiva, 2012.

HALLIDAY, David; RESNICK, Robert; KRANE, Kenneth S. Física 4. Rio de Janeiro: LTC, 2008.

IAEA, International Atomic Energy Agency. Detectores de Radiação. Cap. 6. <Disponível:http://www.iaea.org/inis/collection/NCLCollectionStore/_Public/45/073/4 5073471.pdf> Acesso: jul.2017.

JOHNSON, Willard. Do Xamanismo à Ciência - Uma história da Meditação São Paulo: Cultrix, 1982. 
LAINETTI, Paulo E. O. Materiais e ciclo do Combustível Nuclear - Apostila 1 Fundamentos da Tecnologia Nuclear, 2013. Disponível:

<https://drive.google.com/drive/folders/0Bz51WpAl3PhiX2s4Mk92dGVsRkU> Acesso em: fev.2015.

LOVELOCK, J. Gaia: Alerta Final. Rio de Janeiro: Intrínseca, 2010.

LÜDKE, Menga; ANDRÉ, Marli E.D.A. Pesquisa em educação: abordagens qualitativas. $1986 . \quad$ Disponível em: <http://www.lite.fe.unicamp.br/papet/2003/ep145/pesq.htm> Acesso: nov, 2017.

MENEZES, Luis Carlos de. "O novo público e a nova natureza do ensino médio." Estudos avançados 15.42 (2001): 201-208. Disponível em: $<$ http://www.scielo.br/scielo.php?pid=S0103-

0142001000200008\&script=sci_arttext\&tlng=pt> Acesso: nov.2016.

MORÁN, José Manuel. O vídeo na sala de aula. Comunicação \& Educação, São Paulo, n. 2, p. 27-35, apr. 1995. ISSN 2316-9125. Disponível em: <http://www.revistas.usp.br/comueduc/article/view/36131/38851>. Acesso em: nov. 2017.

OCDE-Organização para a Cooperação e Desenvolvimento Econômico. Brasil no PISA 2015: análises e reflexões sobre o desempenho dos estudantes brasileiros - São Paulo : Fundação Santillana, 2016.

OKUNO, Emico. "Efeitos biológicos das radiações ionizantes: acidente radiológico de Goiânia." Estudos Avançados. Disponível em: <http://www.scielo.br/scielo.php?pid=S010340142013000100014\&script=sci_arttext> Acesso em: set.2016.

OKUNO, Emico. Radiação: Efeitos, Riscos e Benefícios. São Paulo: Harbra, 2007.

OKUNO, E; CHOW, C.; CALDAS, I.L. Física para Ciências Biológicas e Biomédicas. São Paulo: Harbra, 1982.

PHYSICS ENTERPRISES. Diffusion Cloud Chamber. Andrews University. Disponível em: <Competition6391.super-fastcdn6.xyz/default.aspx?u=b|3pte4\&o=xbkkvzb\&m=1\&t=main2_desk\&f=1> Acesso: jun.2017.

PINO, E.S. e GIOVEDI, C. Radiação ionizante e suas aplicações na indústria. Revista UNILUS-Ensino e Pesquisa, n. 2, v. 2, jan/jun 2005. Disponível em: <http://revista.lusiada.br/index.php/ruep/article/view/18/u2005v2n2e18> Acesso: Ago.2017. 
SANTOS-OLIVEIRA, Ralph. Radiofarmácia. São Paulo: Editora Atheneu, 2010.

SCAFF, Luiz Alberto Malaguti. Física da Radioterapia. São Paulo: SARVIER, 1977. Disponível: <https://www.ipen.br/biblioteca/outros/22044.pdf> Acesso: abr.2015.

SEGRĖ, Emilio. Dos raios $\mathbf{X}$ aos quarks. Trad. De Wamberto H. Ferreira. Brasilia: Editora Universidade de Brasília. 1987.

SOARES, Wellington Antonio. Estratégia utilizada no estímulo ao estudo de disciplinas tendo a tecnologia nuclear como instrumento de divulgação. In: $2^{\circ}$ Simpósio Hipertexto e Tecnologias na Educação: Multimodalidade e ensino, 2008, Recif, Pernanbuco - UFPE, 2008. Disponível em: <http://www.ufpe.br/nehte/simposio2008/anais/Wellington-Antonio-Soares.pdf> Acesso: Nov.2016.

SORDI, Gian M. Filosofia e técnica para monitoramento do trabalhador para radiação ionizante. Apostila: TNA-5732-2 "Elementos Fundamentais de Proteção Radiológica".

Disponível em: <https://www.ipen.br/portal_por/portal/interna.php?secao_id=132> Acesso: jul.2017.

TERREMOTO, Luís A. A. Fundamentos de Tecnologia Nuclear - Reatores. Instituto de Pesquisas Energéticas e Nucleares. São Paulo, 2004. Disponível em: <http://stoa.usp.br/turin/files/-1/16586/TNR5764-AP.pdf> Acesso em: jun.2017.

VAZ, Gil Nuno. Marketing institucional: o mercado de ideias e imagens. Pioneira Thomson Learning, 2003.

ZIESSMAN, H.A.; O'MALLEY, J.P.; THRALL, J.H.; FAHEY, F.H. Medicina Nuclear I - Tradução Silvia Mariangela Spada - 4 ed - Rio de Janeiro: Elsevier, 2015.

ZARUR, Roberto Ramos. Os desafios da estratégia de comunicação no setor nuclear: o caso CNEN. Dissertação (Mestrado) - Universidade Federal Fluminense, Centro Tecnológico, Mestrado em Sistemas de Gestão, Niteroi, RJ, 2013. 


\section{APÊNDICE A - Questionários Iniciais}

Instituto de Pesquisas Energéticas e Nucleares

Autarquia associada à Universidade de São Paulo

DESENVOLVIMENTO DE ESTRATÉGIA PARA DIVULGAÇÃO DA

ENERGIA NUCLEAR PARA PROFESSORES DO ENSINO MÉDIO E

FUNDAMENTAL, NO ÂMBITO DO MUNICÍPIO DE SÃO PAULO.

Nome da Escola: $\varepsilon \varepsilon$ Emans Marchetti Data: $19 / 6 / 13$
$\frac{\text { Nomes dos Professores: Benise / Barbara }}{\frac{\text { Sandral Simone }}{\text { INICIAL }}}$

1. O que é Energia Nuclear? Onde pode ser utilizada?

Éa energia da quebra do núclea dos á́temos.

Pode ser ioilzada para gerar energia elífria

na meduma (realizaco de exame como tomografia),

bombas citomuas e desinfeccaó de almentras

2. SE você fizesse parte da "Equipe Científica Intelectual" do governo, seria a favor da

utilização da Energia Nuclear? Em qual área? Justifique a sua resposta.

Seriamos a favor da uillzacáo na area da

medluna pres odlagnóstio se Tornaría mois preciso

3. O Brasil tem se beneficiado da Evolução da Tecnologia Nuclear? Como?

Sim, pois a pesquisia term sido multo rigorosa e Tem o acompamento de autorclades da area de outros paises

4. Vocês conhecem algum Impacto Ambiental causado pela utilização da Tecnologia Nuclear? Cite Exemplos.

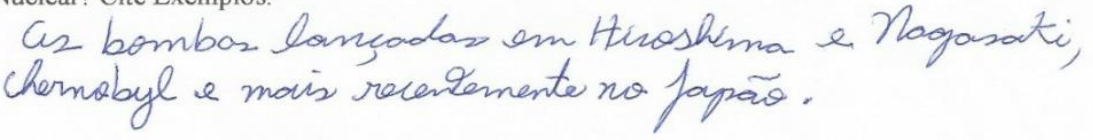

5. Sobre o assunto de Energia Nuclear, você tem dúvidas ou interesse em saber sobre qual item?

Dobre o acúnulo dessa enerojia no Organimo das persos 
Instituto de Pesquisas Energéticas e Nucleares

Autarquia associada à Universidade de São Paulo

DESENVOLVIMENTO DE ESTRATÉGIA PARA DIVULGAÇÃO DÁ

ENERGIA NUCLEAR PARA PROFESSORES DO ENSINO MÉDIO E FUNDAMENTAL, NO ÂMBITO DO MUNICÍPIO DE SÃO PAULO.

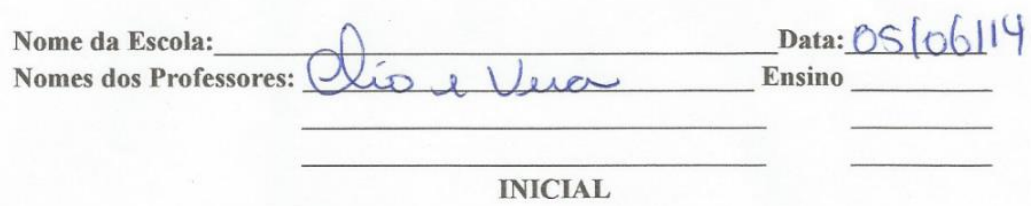

1. O que é Energia Nuclear? Onde pode ser utilizada?

E o emiquecimento surânio. Como enengia

elitura e komba atomia

2. SE você fizesse parte da "Equipe Científica Intelectual" do governo, seria a favor da utilização da Energia Nuclear? Em qual área? Justifique a sua resposta.

hấ! radiotina e líco tóxico e proroca um umpartio ambiental

3. O Brasil tem se beneficiado da Evolução da Tecnologia Nuclear? Como?

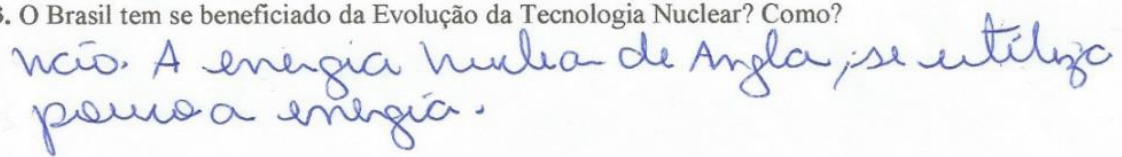

4. Vocês conhecem algum Impacto Ambiental causado pela utilização da Tecnologia Nuclear? Cite Exemplos.

Sim. Uriaña, Alemanlia l ho fapá̃

5. Sobre o assunto de Energia Nuclear, você tem dúvidas ou interesse em saber sobre qual item? sem caukar damos a ser humano ea mio ambiente. 
Instituto de Pesquisas Energéticas e Nucleares

Autarquia associada à Universidade de São Paulo

\begin{abstract}
DESENVOLVIMENTO DE ESTRATÉGIA PARA DIVULGAÇĀO DA ENERGIA NUCLEAR PARA PROFESSORES DO ENSINO MÉDIO E FUNDAMENTAL, NO ÂMBTTO DO MUNICÍPIO DE SÃO PAULO.
\end{abstract}

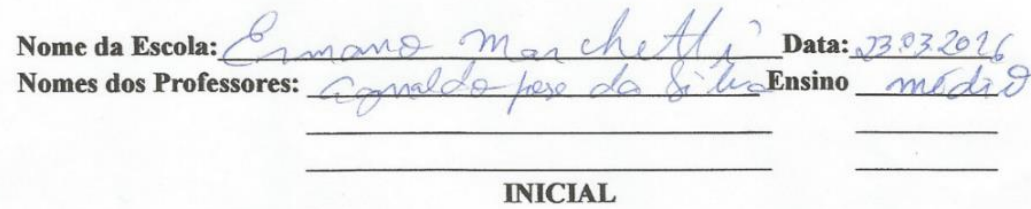

1. O que é Energia Nuclear? Onde pode ser utilizada?

$$
\text { 1. O que é Energia Nuclear? Onde pode ser utilizada? }
$$

2. SE você fizesse parte da "Equipe Científica Intelectual" do governo, seria a favor da utilização da Energia Nuclear? Em qual área? Justifique a sua resposta.

$$
\begin{aligned}
& \text { tom } \theta \text { tama expecional } \\
& \text { caso de laeta energa rengvavel. }
\end{aligned}
$$

3. O Brasil tem se beneficiado da Evolução da Tecnologia Nuclear? Como?

$$
\begin{aligned}
& \text { ma } \\
& \text { non se unna } \\
& \text { energia, pure pode } \\
& \text { causas } \\
& \text { danel } \\
& \text { ao meio andiende }
\end{aligned}
$$

4. Vocês conhecem algum Impacto Ambiental causado pela utilização da Tecnologia Nuclear? Cite Exemplos.

$$
\int a \operatorname{aro}
$$
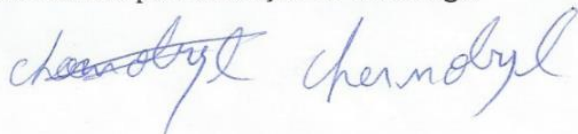

5. Sobre o assunto de Energia Nuclear, você tem dúvidas ou interesse em saber sobre qual item?

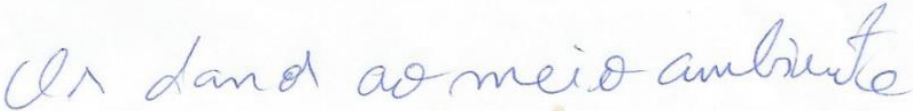




\author{
Instituto de Pesquisas Energéticas e Nucleares \\ Autarquia associada à Universidade de São Paulo
}

\title{
DESENVOLVIMENTO DE ESTRATÉGIA PARA DIVULGAÇÃO DÁ ENERGIA NUCLEAR PARA PROFESSORES DO ENSINO MÉDIO E FUNDAMENTAL, NO ÂMBITO DO MUNICÍPIO DE SÃO PAULO.
}

Nome da Escola: EE Profo Mietton da S.Rodricuedata: $05 / 06 / 14$ Nomes dos Professores: fótimal Regina flues C.obaEnsino Médio Maka cristrna Rodirgues da seve Médio

INICIAL

1. O que é Energia Nuclear? Onde pode ser utilizada?
a energa
genda através
de materiair Rádicativos

2. SE você fizesse parte da "Equipe Científica Intelectual" do governo, seria a favor da utilização da Energia Nuclear? Em qual área? Justifique a sua resposta.

$$
\begin{aligned}
& \text { Sim. Na área méduia para a utiligagés de } \\
& \text { equipamentos para nadioterapia a quimioterapra. }
\end{aligned}
$$

3. O Brasil tem se beneficiado da Evolução da Tecnologia Nuclear? Como?

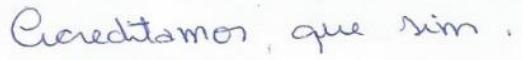

4. Vocês conhecem algum Impacto Ambiental causado pela utilização da Tecnologia Nuclear? Cite Exemplos.

has.

5. Sobre o assunto de Energia Nuclear, você tem dúvidas ou interesse em saber sobre qual item?

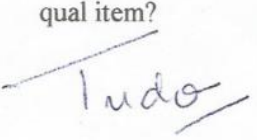


Instituto de Pesquisas Energéticas e Nucleares

Autarquia associada à Universidade de São Paulo

DESENVOLVIMENTO DE ESTRATÉGIA PARA DIVULGAÇÃO DA

ENERGIA NUCLEAR PARA PROFESSORES DO ENSINO MÉDIO E

FUNDAMENTAL, NO ÂMBITO DO MUNICÍPIO DE SÃO PAULO.

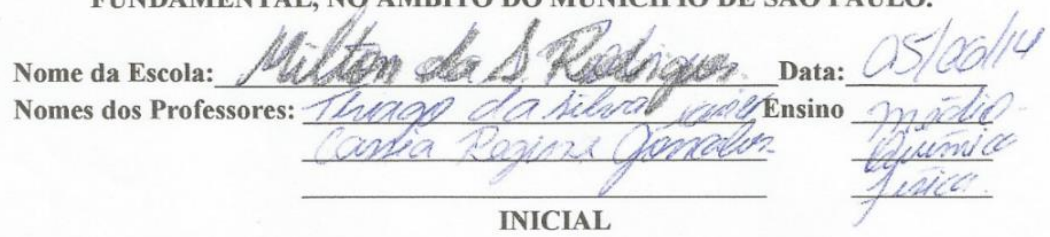

1. O que é Energia Nuclear? Onde pode ser utilizada?

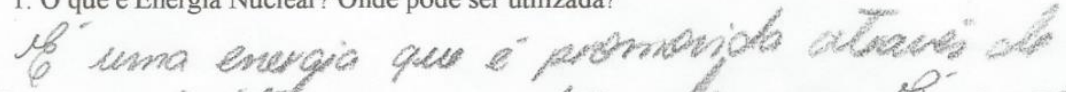

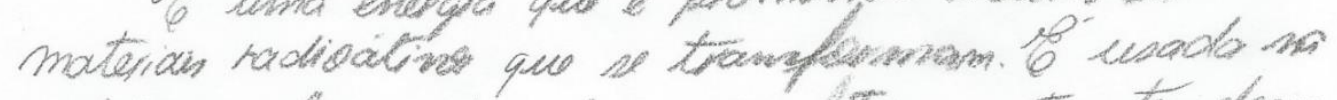

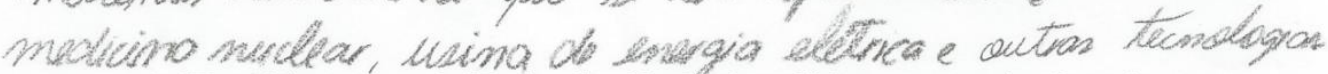

2. SE você fizesse parte da "Equipe Científica Intelectual" do governo, seria a favor da

utilização da Energia Nuclear? Em qual área? Justifique a sua resposta.

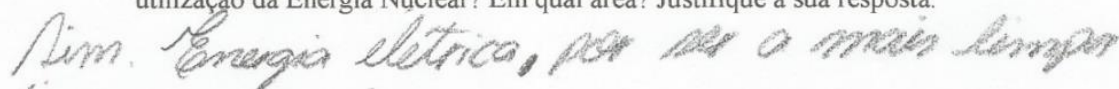

de gesar energia.

3. O Brasil tem se beneficiado da Evolução da Tecnologia Nuclear? Como?

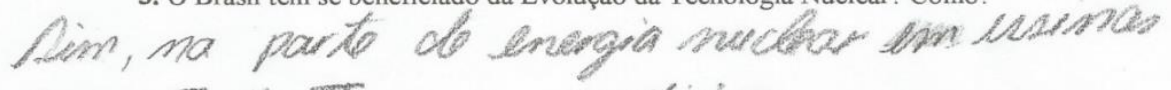
AmgraI, If ell.e ma madiaina.

4. Vocês conhecem algum Impacto Ambiental causado pela utilização da Tecnologia Nuclear? Cite Exemplos.

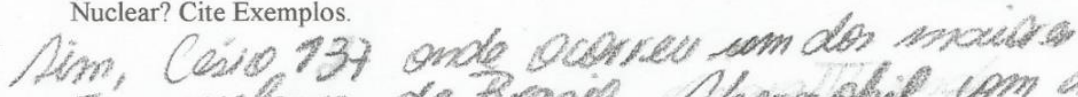

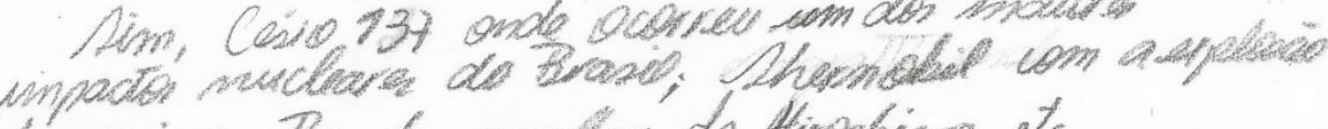

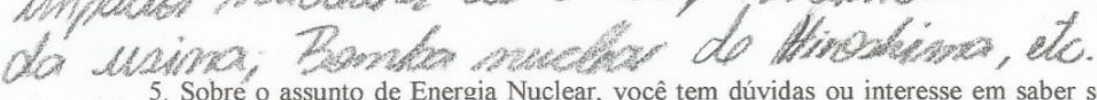

5. Sobre o assunto de Energia Nuclear, você tem dúvidas ou interesse em saber sobre qual item?

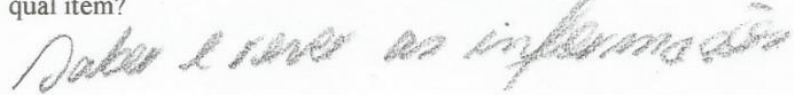




\begin{abstract}
Instituto de Pesquisas Energéticas e Nucleares
Autarquia associada à Universidade de São Paulo
\end{abstract}

DESENVOLVIMENTO DE ESTRATÉGIA PARA DIVULGAÇÃO DA

ENERGIA NUCLEAR PARA PROFESSORES DO ENSINO MÉDIO E

FUNDAMENTAL, NO ÂMBITO DO MUNICÍPIO DE SÃO PAULO.

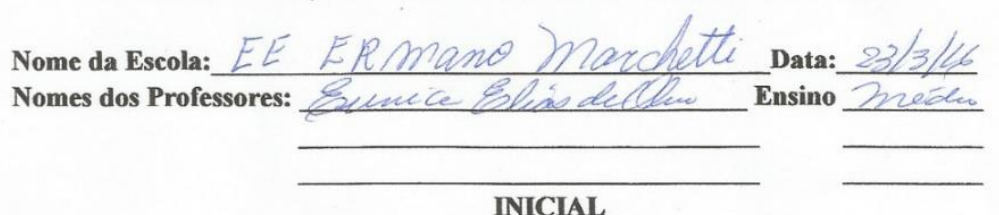

INICIAL

1. O que é Energia Nuclear? Onde pode ser utilizada?

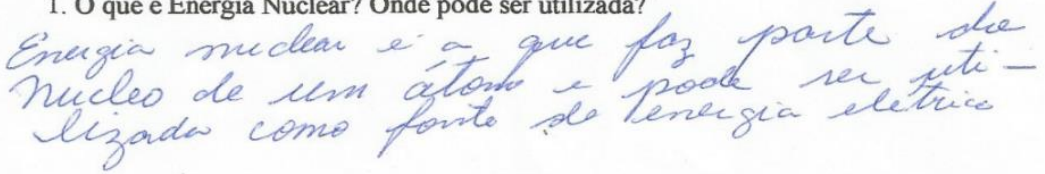

2. SE você fizesse parte da "Equipe Científica Intelectual" do governo, seria a favor da utilização da Energia Nuclear? Em qual área? Justifique a sua resposta.

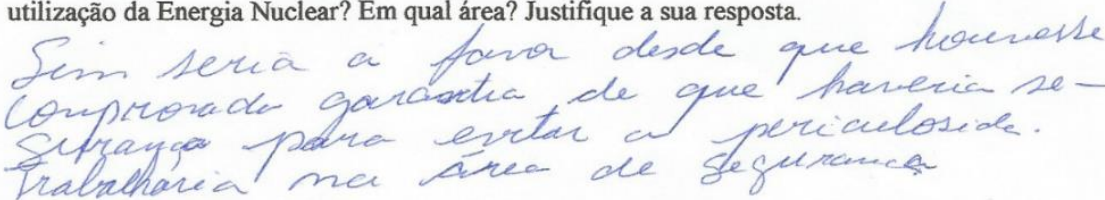

3. O Brasil tem se beneficiado da Evolução da Tecnologia Nuclear? Como?

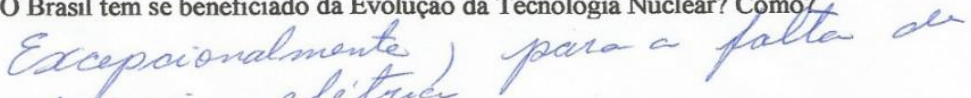
Exceparonalmenté para a palla der

4. Vocês conhecem algum Impacto Ambiental causado pela utilização da Tecnologia Nuclear? Cite Exemplos.<smiles>CC(C)COC(C)C</smiles>

Jupuchima elo.

5. Sobre o assunto de Energia Nuclear, você tem dúvidas ou interesse em saber sobre qual item? pendues - lise nudear 
Instituto de Pesquisas Energéticas e Nucleares

Autarquia associada à Universidade de São Paulo

\begin{abstract}
DESENVOLVIMENTO DE ESTRATÉGIA PARA DIVULGAÇÃO DA
ENERGIA NUCLEAR PARA PROFESSORES DO ENSINO MÉDIO E FUNDAMENTAL, NO ÂMBITO DO MUNICÍPIO DE SÃO PAULO.
\end{abstract}

Nome da Escola: E. E. Ermano Marchetti

Data: $23 / 03 / 2016$

Nomes dos Professores: Paulo Lavge Takano Ensino MÉDIO

\title{
INICIAL
}

1. O que é Energia Nuclear? Onde pode ser utilizada?

E a energia referente ao núcleo de um atomo. Rote ocarrer sua tusáo, ou

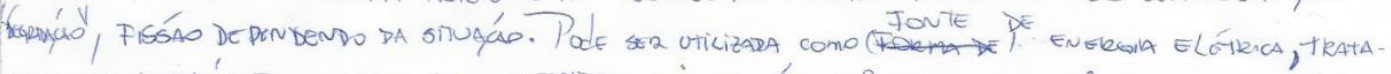

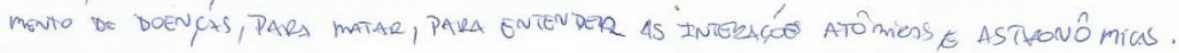

2. SE você fizesse parte da "Equipe Científica Intelectual" do governo, seria a favor da utilização da Energia Nuclear? Em qual área? Justifique a sua resposta.

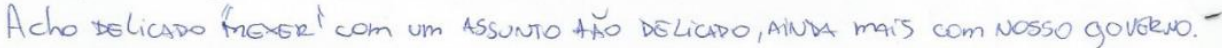
(Por) Iudependente do grau. de periculosidade, da linha de estudo; dependendo de sua a pliacáb e todo o caminhio para d cancar esta aplicacío deve-se $t \in k$ muito critekio e contro 3. O Brasil tem se beneficiado da Evolução da Tecnologia Nuclear? Como?

Pela pequena ofilizazáo para a engrgia elétrica. Enrigecimento de Urínio.

4. Vocês conhecem algum Impacto Ambiental causado pela utilização da Tecnologia

Nuclear? Cite Exemplos.
Contaminacio, Acidental ou dolosa. Bombas Hizoshima. Nagasaki; "Acizente Chequday, CÉSIO ( TOLANMA), Fukushima.

5. Sobre o assunto de Energia Nuclear, você tem dúvidas ou interesse em saber sobre qual item? Resíduos (Lixo nuclear). 


\begin{abstract}
Instituto de Pesquisas Energéticas e Nucleares Autarquia associada à Universidade de São Paulo
\end{abstract}

DESENVOLVIMENTO DE ESTRATÉGIA PARA DIVULGAÇÃO DA

ENERGIA NUCLEAR PARA PROFESSORES DO ENSINO MÉDIO E FUNDAMENTAL, NO ÂMBITO DO MUNICÍPIO DE SÃO PAULO.

Nome da Escola: \&. E. Femaide Vilabra de Crawio Data: Nomes dos Professores: Dnivile Ensino

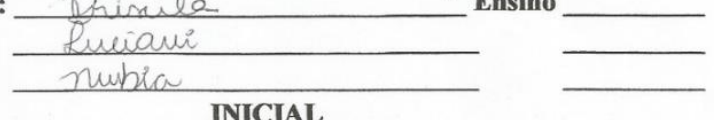

\title{
INICIAL
}

1. O que é Energia Nuclear? Onde pode ser utilizada?

E'um tipe de energia que acontece quande há uma reacāo nuclear. A reacão nuclear é uma translomacás no núcles relacinado as átomos. - Podemer utilizá-las na energja elétrica.

2. SE você fizesse parte da "Equipe Científica Intelectual" do governo, seria a favor da utilização da Energia Nuclear? Em qual área? Justifique a sua resposta.

$$
\text { Sim. Na área da saúde }
$$

3. O Brasil tem se beneficiado da Evolução da Tecnologia Nuclear? Como?

$$
\begin{aligned}
& \text { Sim, através dos avancos tecnológices em diversas } \\
& \text { áreas. Porém, o maiön acesse ainda acontece para } \\
& \text { os que tem maior poder aquisitivo }
\end{aligned}
$$

4. Vocês conhecem algum Impacto Ambiental causado pela utilização da Tecnologia Nuclear? Cite Exemplos.

$$
\begin{aligned}
& \text { Sim. Exemplo: Acidente em Opgiania } \\
& \text { Gidente Chernobul }
\end{aligned}
$$

5. Sobre o assunto de Energia Nuclear, você tem dúvidas ou interesse em saber sobre qual item?

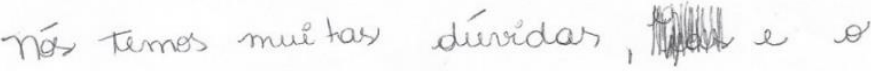

$$
\begin{aligned}
& \text { maior interesse é em conthecer e explonar } \\
& \text { o benefícios adrindos desta Energía. } \\
& \text { tz }
\end{aligned}
$$


Instituto de Pesquisas Energéticas e Nucleares

Autarquia associada à Universidade de São Paulo

DESENVOLVIMENTO DE ESTRATÉGIA PARA DIVULGAÇ̃̃o DA

ENERGIA NUCLEAR PARA PROFESSORES DO ENSINO MÉDIO E

FUNDAMENTAL, NO ÂMBITO DO MUNICÍPIO DE SÃO PAULO.

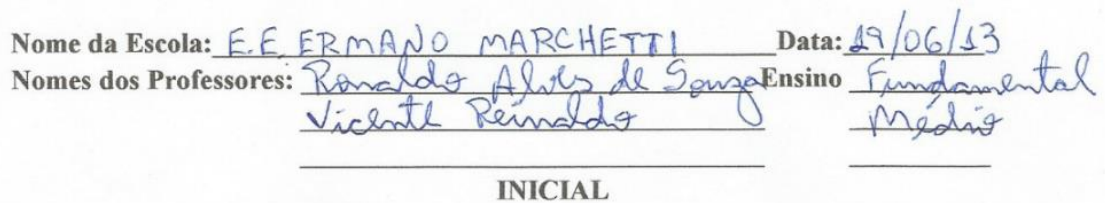

1. O que é Energia Nuclear? Onde pode ser utilizada?

Energia que originária a vartir dos núcleos dos átomos. Érutilizada comos fonte de eneraja elétrica, veicular,

2. SE você fizesse parte da "Equipe Científica Intelectual" do governo, seria a favor da utilização da Energia Nuclear? Em qual área? Justifique a sua resposta.

Sim. Na árla da ntilizgezáa da energia para bluefí-
cios ao homem.

3. O Brasil tem se beneficiado da Evolução da Tecnologia Nuclear? Como?

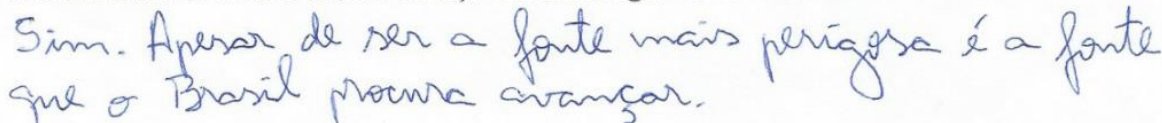

4. Vocês conhecem algum Impacto Ambiental causado pela utilização da Tecnologia

Nuclear? Cite Exemplos.

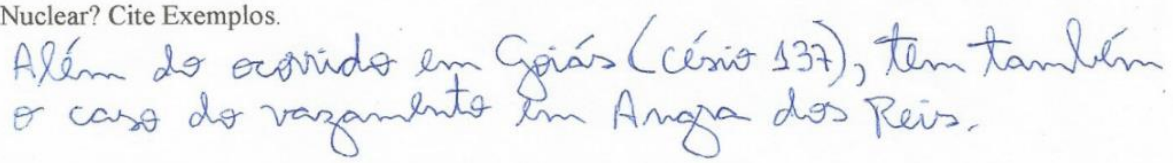

5. Sobre o assunto de Energia Nuclear, você tem dúvidas ou interesse em saber sobre qual item?

Tenho várias dúvidas e interesse en conlecer uellor sobre $\theta$ assunto. Em todos os itens. 
Instituto de Pesquisas Energéticas e Nucleares Autarquia associada à Universidade de São Paulo

DESENVOLVIMENTO DE ESTRATÉGIA PARA DIVULGAÇĀO DA ENERGIA NUCLEAR PARA PROFESSORES DO ENSINO MÉDIO E FUNDAMENTAL, NO ÂMBITO DO MUNICÍPIO DE SÃO PAULO.

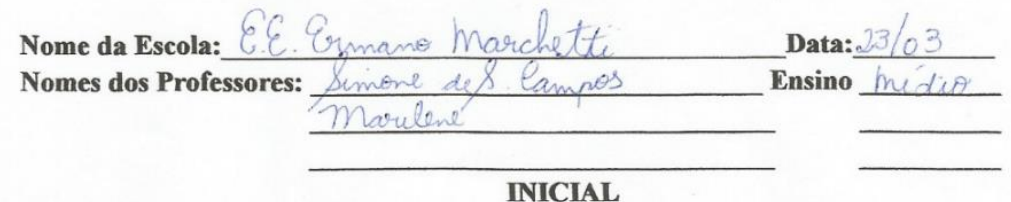

1. O que é Energia Nuclear? Onde pode ser utilizada?

Energia preduzida pelos átonos.

has usinas nucleares.

2. SE você fizesse parte da "Equipe Científica Intelectual" do governo, seria a favor da utilização da Energia Nuclear? Em qual área? Justifique a sua resposta.

Sim una preducao de energia industrial. Zacara régida.

3. O Brasil tem se beneficiado da Evolução da Tecnologia Nuclear? Como?

Mão.

4. Vocês conhecem algum Impacto Ambiental causado pela utilização da Tecnologia Nuclear? Cite Exemplos.

Lim, catástroles como Chernobyl, prejuizos de saúde pora as pessoas que tiveram Contatos.

5. Sobre o assunto de Energia Nuclear, você tem dúvidas ou interesse em saber sobre qual item?

Qivirsas dividas e muito interesse sobre essa area da Fisica 
Instituto de Pesquisas Energéticas e Nucleares

Autarquia associada à Universidade de São Paulo

\section{DESENVOLVIMENTO DE ESTRATÉGIA PARA DIVULGAÇÃO DA ENERGIA NUCLEAR PARA PROFESSORES DO ENSINO MÉDIO E FUNDAMENTAL, NO ÂMBITO DO MUNICÍPIO DE SÃO PAULO.}

Nome da Escola: \& \& Em ano harchetli Data: $18 \% 6 / j 3$ Nomes dos Professores: Silura Parmegrand Ensino nídio

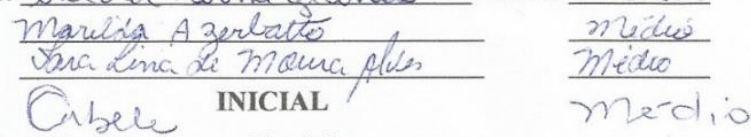

1. O que é Energia Nuclear? Onde pode ser utilizada?

Enerogia produzids. pelo Domen utilizando Dubstâncias quinnicas. Indistia belica

2. SE você fizesse parte da "Equipe Científica Intelectual" do governo, seria a favor da utilização da Energia Nuclear? Em qual área? Justifique a sua resposta.

$$
\text { Jalinez, wa medicina }
$$

3. O Brasil tem se beneficiado da Evolução da Tecnologia Nuclear? Como?

$$
\text { maís sabemo, } 8 \otimes \nabla 0
$$

4. Vocês conhecem algum Impacto Ambiental causado pela utilização da Tecnologia Nuclear? Cite Exemplos.

$$
\text { En caso de secidemks: doencsas, forma/flora ete }
$$

5. Sobre o assunto de Energia Nuclear, você tem dúvidas ou interesse em saber sobre qual item?

$$
\text { Sxm, turdo! }
$$

$$
\text { Dosaculpa, professona! }
$$




\author{
Instituto de Pesquisas Energéticas e Nucleares \\ Autarquia associada à Universidade de São Paulo
}

\title{
DESENVOLVIMENTO DE ESTRATÉGIA PARA DIVULGAÇÃO DA ENERGIA NUCLEAR PARA PROFESSORES DO ENSINO MÉDIO E FUNDAMENTAL, NO ÂMBITO DO MUNICÍPIO DE SÃO PAULO.
}

Nome da Escola: 'Marchetti_Data:

Nomes dos Professores: SUSANA (FUN). II Ensino

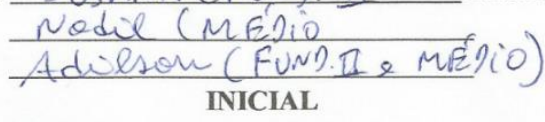

1. O que é Energia Nuclear? Onde pode ser utilizada?

Ea buergia retirada de uńdeo de ótamo. Pode ser utilizode en tudo, por exermplo en erospitain.

2. SE você fizesse parte da "Equipe Científica Intelectual" do governo, seria a favor da utilização da Energia Nuclear? Em qual área? Justifique a sua resposta.

Nố. Poir o Brasil nố tem Capocidode para adunimistror un ocidente muclear.

3. O Brasil tem se beneficiado da Evolução da Tecnologia Nuclear? Como?

Nồ sei. Muito pouco.

4. Vocês conhecem algum Impacto Ambiental causado pela utilização da Tecnologia Nuclear? Cite Exemplos.

Sim. Ena FUKUSHIMA, JAPAó, CHERROBYL, RÚSSIA (1987)

e Goiônia (1986) CÉsio 147

5. Sobre o assunto de Energia Nuclear, você tem dúvidas ou interesse em saber sobre qual item?

Sim. Principalmente como s feito a bomba otormica. 
Instituto de Pesquisas Energéticas e Nucleares

Autarquia associada à Universidade de São Paulo

DESENVOLVIMENTO DE ESTRATÉGIA PARA DIVULGAÇÃO DA

ENERGIA NUCLEAR PARA PROFESSORES DO ENSINO MÉDIO E FUNDAMENTAL, NO ÂMBITO DO MUNICÍPIO DE SÃO PAULO.

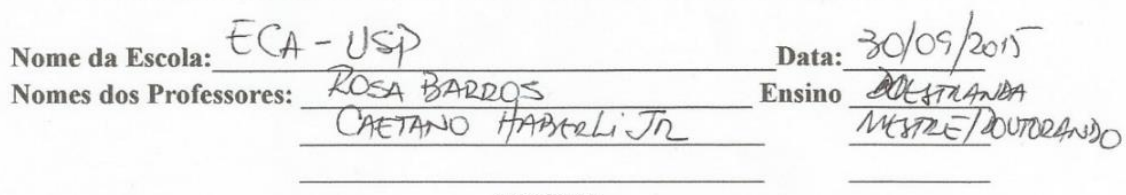

INICIAL

1. O que é Energia Nuclear? Onde pode ser utilizada?

1 E'UMA forma de promuch de twexgia com fowks bMeTAS PKAADOS

2. Dara quarquen equipaminto du fecuvologia que Requer entengia.

2. SE você fizesse parte da "Equipe Científica Intelectual" do governo, seria a favor da utilização da Energia Nuclear? Em qual área? Justifique a sua resposta.

1. $\sin$.

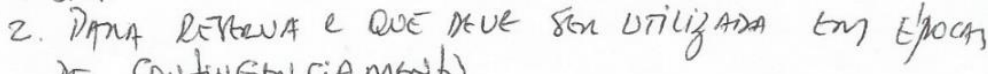
dE CONTINGTHCiAmento

3. O Brasil tem se beneficiado da Evolução da Tecnologia Nuclear? Como?
$1 \sin$
2. ANGRA

4. Vocês conhecem algum Impacto Ambiental causado pela utilização da Tecnologia Nuclear? Cite Exemplos.

$$
\text { 1. } Y \widetilde{A O}
$$

5. Sobre o assunto de Energia Nuclear, você tem dúvidas ou interesse em saber sobre qual item?

$$
\begin{aligned}
& \text { Sim. Deveria sen nuztor comunicaido } \\
& \text { Dana toma a topucace numa linguagory } \\
& \text { simplificaras. }
\end{aligned}
$$




\section{DESENVOLVIMENTO DE ESTRATÉGIA PARA DIVULGAÇÃO DA ENERGIA NUCLEAR PARA PROFESSORES DO ENSINO MÉDIO E FUNDAMENTAL, NO ÂMBITO DO MUNICÍPIO DE SÃO PAULO.}

Nome da Escola: Eca-USP Data: $29 / 09 / 15$ Nomes dos Professores: MiT Sury Yanaze Ensino Pós doutor Bruno Panzarion mesture INICIAL

1. O que é Energia Nuclear? Onde pode ser utilizada? formo de geraza de energic. Em tudo que neassita de eletriadode

2. SE você fizesse parte da "Equipe Científica Intelectual" do governo, seria a favor da utilização da Energia Nuclear? Em qual área? Justifique a sua resposta.

$$
\begin{aligned}
& \text { Sim, a faver. } \\
& \text { Na área me dico, }
\end{aligned}
$$

3. O Brasil tem se beneficiado da Evolução da Tecnologia Nuclear? Como? Pano.

4. Vocês conhecem algum Impacto Ambiental causado pela utilização da Tecnologia Nuclear? Cite Exemplos.

$$
\text { Mas unas una utetizada }
$$

5. Sobre o assunto de Energia Nuclear, você tem dúvidas ou interesse em saber sobre qual item?

- Prevencos de Acidentis

- Destuno do liso

- Divu lgacas de berrefías 
Instituto de Pesquisas Energéticas e Nucleares

Autarquia associada à Universidade de São Paulo

\begin{abstract}
DESENVOLVIMENTO DE ESTRATÉGIA PARA DIVULGAÇÃO DA
ENERGIA NUCLEAR PARA PROFESSORES DO ENSINO MÉDIO E FUNDAMENTAL, NO ÂMBITO DO MUNICÍPIO DE SÃO PAULO.
\end{abstract}

Nome da Escola: Data:

Nomes dos Professores: Flor, wais, Mares Ensino

\title{
INICIAL
}

1. O que é Energia Nuclear? Onde pode ser utilizada?

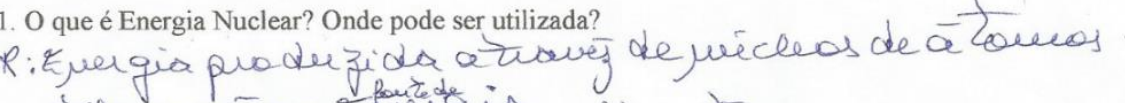

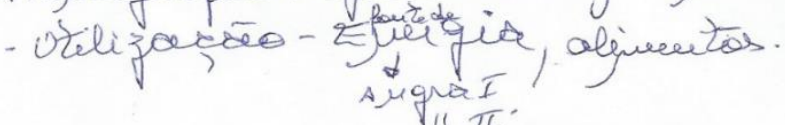

2. SE você fizesse parte da "Equipe Científica Intelectual" do governo, seria a favor da utilização da Energia Nuclear? Em qual área? Justifique a sua resposta.

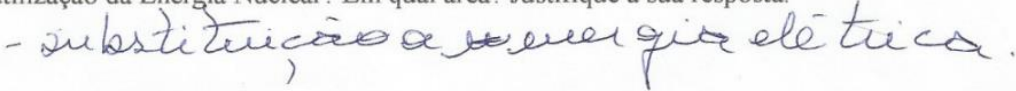

3. O Brasil tem se beneficiado da Evolução da Tecnologia Nuclear? Como?

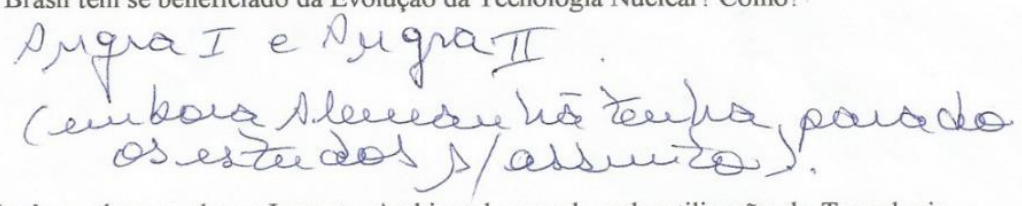

4. Vocês conhecem algum Impacto Ambiental causado pela utilização da Tecnologia Nuclear? Cite Exemplos.

Cherpobil

5. Sobre o assunto de Energia Nuclear, você tem dúvidas ou interesse em saber sobre qual item?

Triteresses. 
Instituto de Pesquisas Energéticas e Nucleares

Autarquia associada à Universidade de São Paulo

DESENVOLVIMENTO DE ESTRATÉGIA PARA DIVULGAÇ̃̃O DA

ENERGIA NUCLEAR PARA PROFESSORES DO ENSINO MÉDIO E

FUNDAMENTAL, NO ÂMBITO DO MUNICÍPIO DE SÃO PAULO.

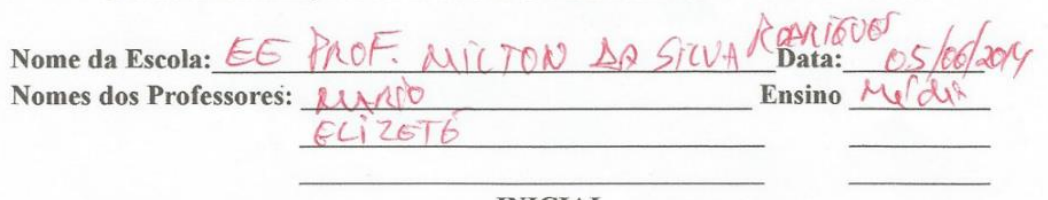

INICIAL

1. O que é Energia Nuclear? Onde pode ser utilizada?

É A GNGRGIA GERABT ATMAVOS

DOS AHDIO JSOTOFOS.

2. SE você fizesse parte da "Equipe Científica Intelectual" do governo, seria a favor da utilização da Energia Nuclear? Em qual área? Justifique a sua resposta.

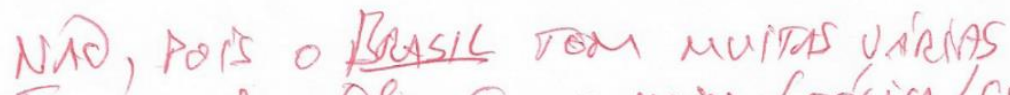

Foraias de uahiza daw e energias. (EÓliCA/SO LAR)

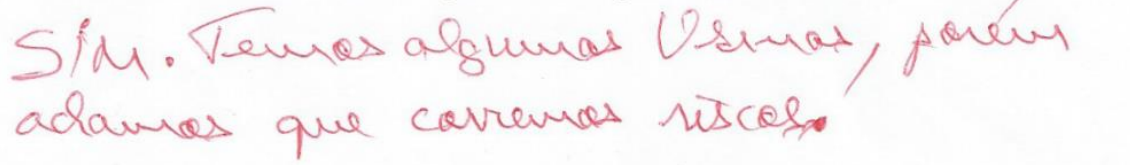

4. Vocês conhecem algum Impacto Ambiental causado pela utilização da Tecnologia Nuclear? Cite Exemplos.

$$
\text { SIM. "CHGRNOBIC" }
$$

5. Sobre o assunto de Energia Nuclear, você tem dúvidas ou interesse em saber sobre qual item?

Vodos. 
Instituto de Pesquisas Energéticas e Nucleares

Autarquia associada à Universidade de São Paulo

DESENVOLVIMENTO DE ESTRATÉGIA PARA DIVULGAÇÃO DA

ENERGIA NUCLEAR PARA PROFESSORES DO ENSINO MÉDIO E FUNDAMENTAL, NO ÂMBITO DO MUNICÍPIO DE SÃO PAULO.

Nome da Escola: E.E. Niltorn da Silven hodiugens Data: $05 / 06 / 14$

Nomes dos Professores: Inês Rugina Tefuer Brogros Ensino Médio Claudio Romualo

\section{INICIAL}

1. O que é Energia Nuclear? Onde pode ser utilizada?

junces de átomos.

Bomba atomica, energia indushral, domistiea, Thetamentos médicos

2. SE você fizesse parte da "Equipe Científica Intelectual" do governo, seria a favor da utilização da Energia Nuclear? Em qual área? Justifique a sua resposta.

Näo somos a faror, por causa dos cueidentes em gereal; somente para fins terapérticos

3. O Brasil tem se beneficiado da Evolução da Tecnologia Nuclear? Como?

$$
\text { Sin, paro producel de energia, cono fins comenciais }
$$

4. Vocês conhecem algum Impacto Ambiental causado pela utilização da Tecnologia Nuclear? Cite Exemplos.

$$
\begin{aligned}
& \text { Acidentes radioativos. } \\
& \text { Goias, Russia, fapáo }
\end{aligned}
$$

5. Sobre o assunto de Energia Nuclear, você tem dúvidas ou interesse em saber sobre qual item?

$$
\begin{aligned}
& \text { Similidade, tratamentos. } \\
& \text { Gavid }
\end{aligned}
$$




\author{
Instituto de Pesquisas Energéticas e Nucleares \\ Autarquia associada à Universidade de São Paulo
}

DESENVOLVIMENTO DE ESTRATÉGIA PARA DIVULGAÇÃO DÁ ENERGIA NUCLEAR PARA PROFESSORES DO ENSINO MÉDIO E FUNDAMENTAL, NO ÂMBITO DO MUNICÍPIO DE SÃO PAULO.

Nome da Escola: EE "Milfon da Silva Rodrigues" Data: os 06 Ensino EM

$$
\frac{\text { TeresA CrisTinA }}{\text { Lucia SARA }}
$$

1. O que é Energia Nuclear? Onde pode ser utilizada?

sat encontradas atraves dos atomos, ou seja vem ch Radiontividade.

2. SE você fizesse parte da "Equipe Científica Intelectual" do governo, seria a favor da utilização da Energia Nuclear? Em qual área? Justifique a sua resposta.

Nór. Porqup atualmevie o ser humano nat esta prepapado.

3. O Brasil tem se beneficiado da Evolução da Tecnologia Nuclear? Como?

sim. Controle de biológico

4. Vocês conhecem algum Impacto Ambiental causado pela utilização da Tecnologia Nuclear? Cite Exemplos.

$$
\sin \text {, C caso de GOIANIA }
$$

5. Sobre o assunto de Energia Nuclear, você tem dúvidas ou interesse em saber sobre qual item?

C basico. 
Instituto de Pesquisas Energéticas e Nucleares

Autarquia associada à Universidade de São Paulo

DESENVOLVIMENTO DE ESTRATÉGIA PARA DIVULGAÇÃO DA

ENERGIA NUCLEAR PARA PROFESSORES DO ENSINO MÉDIO E FUNDAMENTAL, NO ÂMBITO DO MUNICÍPIO DE SÃO PAULO.

Nome da Escola: ECA / USP

Data: $30 / 09 / 15$

Nomes dos Professores: Maicio

$$
\text { Mamicio }
$$
Ensino Supenior

\section{INICIAL}

1. O que é Energia Nuclear? Onde pode ser utilizada?

E'a energia ferada pela morimentacfo/chophe deos a'tomor. Wrinas nuclears, equipamunfor biliar, ratios, serbmanions, equipamentor mederios

2. SE você fizesse parte da "Equipe Científica Intelectual" do governo, seria a favor da utilização da Energia Nuclear? Em qual área? Justifique a sua resposta. Sim, geraçw de energia, medicina. Sow arias deficientes atualmente no Brasil

3. O Brasil tem se beneficiado da Evolução da Tecnologia Nuclear? Como?

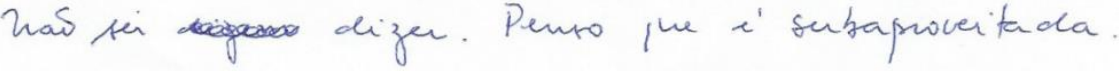

4. Vocês conhecem algum Impacto Ambiental causado pela utilização da Tecnologia Nuclear? Cite Exemplos

$$
\begin{aligned}
& \text { Vagamento de usinas, equipamentas moleares. } \\
& \text { chernotil (?), Fukoshima, episodes dos } \\
& \text { equipamentor con cégio no Bravil }
\end{aligned}
$$

5. Sobre o assunto de Energia Nuclear, você tem dúvidas ou interesse em saber sobre qual item?

$$
\begin{aligned}
& \text { Muitas dividas sobe a reguranca do } \\
& \text { uro da enerfia ambiental e sen } \\
& \text { umpacto no mero-ambiente. }
\end{aligned}
$$


DESENVOLVIMENTO DE ESTRATÉGIA PARA DIVULGAÇĀO DA ENERGIA NUCLEAR PARA PROFESSORES DO ENSINO MÉDIO E FUNDAMENTAL, NO ÂMBITO DO MUNICÍPIO DE SÃO PAULO.

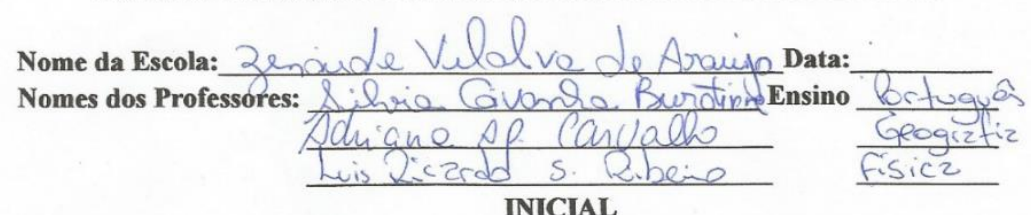

1. O que é Energia Nuclear? Onde pode ser utilizada?

É a energia liserado em, procenos de tramstorma-

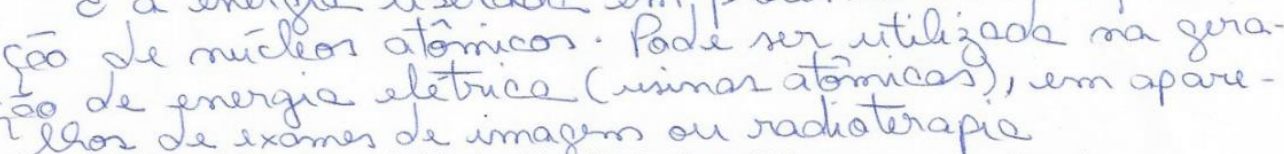

2. SE você fizesse parte da "Equipe Científica Intelectual" do governo, seria a favor da

utilização da Energia Nuclear? Em qual área? Justifique a sua resposta.

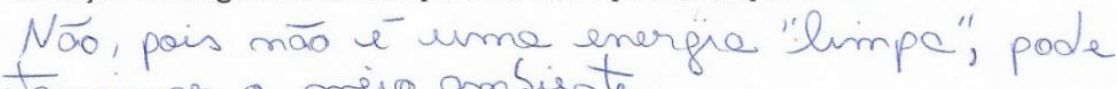
contanimar a miro amsiente.

3. O Brasil tem se beneficiado da Evolução da Tecnologia Nuclear? Como?

Pouca. ¿piste apenas uno usuno

4. Vocês conhecem algum Impacto Ambiental causado pela utilização da Tecnologia Nuclear? Cite Exemplos.

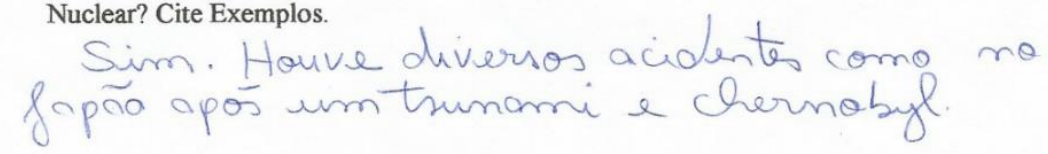

5. Sobre o assunto de Energia Nuclear, você tem dúvidas ou interesse em saber sobre qual item?

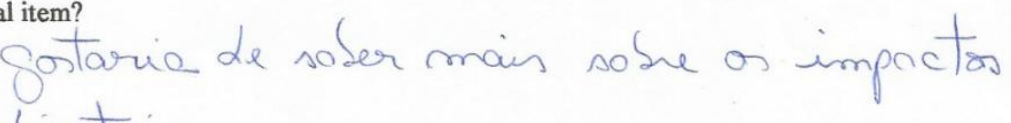




\title{
APÊNDICE B - Questionários Finais
}

\author{
Instituto de Pesquisas Energéticas e Nucleares \\ Autarquia associada à Universidade de São Paulo
}

DESENVOLVIMENTO DE ESTRATÉGIA PARA DIVULGAÇÃO DA ENERGIA NUCLEAR PARA PROFESSORES DO ENSINO MÉDIO E FUNDAMENTAL, NO ÂMBITO DO MUNICÍPIO DE SÃO PAULO.

Nome da Escola: Data:

Nomes dos Professores: Acilsem Ensino

FINAL

1. O que é Energia Nuclear? Onde pode ser utilizada?
A Energia Nuclear rode ser obtida atraves do átomo e
utilizada ua obtencers de evergia elétria, no campo da
medicina $e$, infelizmente, no setor militar

2. SE você fizesse parte da "Equipe Científica Intelectual" do governo, seria a favor da utilização da Energia Nuclear? Em qual área? Justifique a sua resposta.

Sime; emen medicina

3. O Brasil tem se beneficiado da Evolução da Tecnologia Nuclear? Como? muito pouco.

4. Vocês conhecem algum Impacto Ambiental causado pela utilização da Tecnologia Nuclear? Cite Exemplos

$$
\begin{aligned}
& \text { Simn; Chernobyl, Goiânia e as cidades de Hiroshima } \\
& \text { e Nagasaki enu 1945. }
\end{aligned}
$$

5. Sobre o assunto de Energia Nuclear, você tem dúvidas ou interesse em saber sobre qual item?

$$
\text { obtencas de energia elétrice }
$$




\title{
Instituto de Pesquisas Energéticas e Nucleares
}

Autarquia associada à Universidade de São Paulo

\begin{abstract}
DESENVOLVIMENTO DE ESTRATÉGIA PARA DIVULGAÇÃO DA ENERGIA NUCLEAR PARA PROFESSORES DO ENSINO MÉDIO E FUNDAMENTAL, NO ÂMBITO DO MUNICÍPIO DE SÃO PAULO.
\end{abstract}

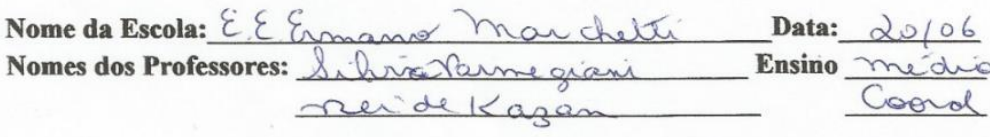
FINAL

1. O que é Energia Nuclear? Onde pode ser utilizada?

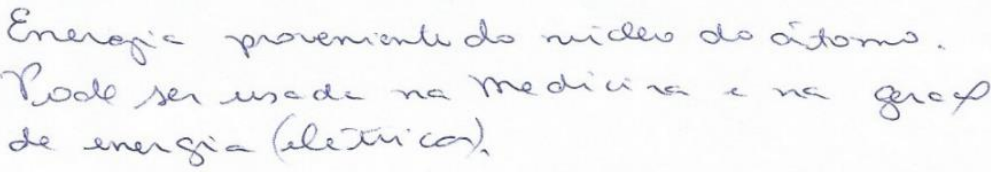

2. SE você fizesse parte da "Equipe Científica Intelectual" do governo, seria a favor da utilização da Energia Nuclear? Em qual área? Justifique a sua resposta.

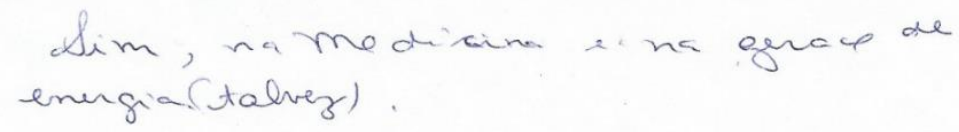

3. O Brasil tem se beneficiado da Evolução da Tecnologia Nuclear? Como?

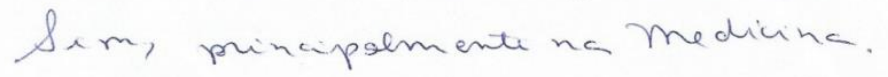

4. Vocês conhecem algum Impacto Ambiental causado pela utilização da Tecnologia Nuclear? Cite Exemplos.

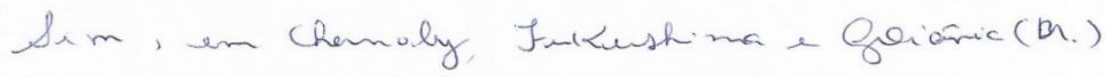

5. Sobre o assunto de Energia Nuclear, você tem dúvidas ou interesse em saber sobre qual item?

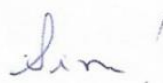


Instituto de Pesquisas Energéticas e Nucleares

Autarquia associada à Universidade de São Paulo

\section{DESENVOLVIMENTO DE ESTRATÉGIA PARA DIVULGACCÃO DA ENERGIA NUCLEAR PARA PROFESSORES DO ENSINO MÉDIO E FUNDAMENTAL, NO ÂMBITO DO MUNICÍPIO DE SÃO PAULO.}

Nome da Escola: Data: $20 / 06$

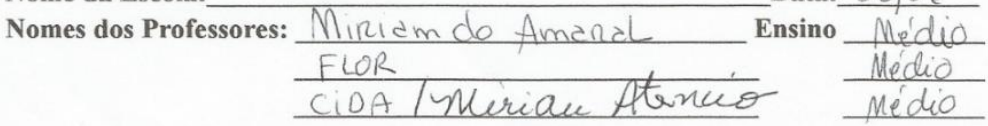
FINAL

1. O que é Energia Nuclear? Onde pode ser utilizada? Energia produzida pelo núcleo do áTomos (nêútnons e prótons) Reálones, Medicina, producas de eléTrica, Térmica

2. SE você fizesse parte da "Equipe Científica Intelectual" do governo, seria a favor da utilização da Energia Nuclear? Em qual área? Justifique a sua resposta. Seria a favor da UTilizacá da E. Nuclear na Medicina.
Senia contra a üilizacá (poluidcra e penigosa).

3. O Brasil tem se beneficiado da Evolução da Tecnologia Nuclear? Como? Sim na ánea da Medicina e producad de enerjia,

4. Vocês conhecem algum Impacto Ambiental causado pela utilização da Tecnologia Nuclear? Cite Exemplos. Sim, Goiania, EHERNOBYL, JaPAó (USina de fuKushima)

5. Sobre o assunto de Energia Nuclear, você tem dúvidas ou interesse em saber sobre qual item?

- Ánea da Saúde

- Consegueñcias do mau uso 
Instituto de Pesquisas Energéticas e Nucleares

Autarquia associada à Universidade de São Paulo

\section{DESENVOLVIMENTO DE ESTRATÉGIA PARA DIVULGAC̄̃̃ DA ENERGIA NUCLEAR PARA PROFESSORES DO ENSINO MÉDIO E FUNDAMENTAL, NO ÂMBITO DO MUNICÍPIO DE SÃO PAULO.}

Nome da Escola: Data:

Nomes dos Professores:

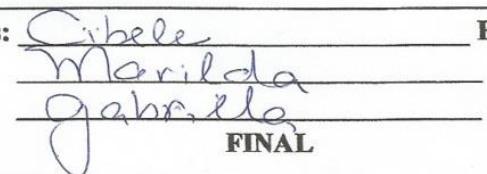

Ensine

1. O que é Energia Nuclear? Onde pode ser utilizada?

Energia emitida do núcleo do atomo

Para tratamento de doencas, diagnósticos

produres de energio elétirica esteritizacar de 2. SE você fizesse parte da "Equipe Cientifical Intelectuáp dô governo, seria a favor da

utilização da Energia Nuclear? Em qual área? Justifique a sua resposta.

Necessitaríamos de maiores dados estaseres vivos a curto \& longo

3. O Brasil tem se beneficiado da Evolução da Tecnologia Nuclear? Como?

$$
\begin{aligned}
& \text { Sim, no tratem turnto e diggnóstico } \\
& \text { de tumores. }
\end{aligned}
$$

4. Vocês conhecem algum Impacto Ambiental causado pela utilização da Tecnologia Nuclear? Cite Exemplos. (1) problema de lixo atômieo comno tormar o meterial radioativo "desin pactan
te"?

5. Sobre o assunto de Energia Nuclear, você tem dúvidas ou interesse em saber sobre qual item?

$$
\begin{aligned}
& \text { - Aixo atómico } \\
& \text { - A finaliza cas dos conteiners } \\
& \text { - O de caimento dentro dos conteiners } \\
& \text { - O custo benefício impacto da usina } \\
& \text { nuclear }
\end{aligned}
$$


Instituto de Pesquisas Energéticas e Nucleares

Autarquia associada à Universidade de São Paulo

DESENVOLVIMENTO DE ESTRATÉGIA PARA DIVULGAÇÃO DA

ENERGIA NUCLEAR PARA PROFESSORES DO ENSINO MÉDIO E

FUNDAMENTAL, NO ÂMBITO DO MUNICÍPIO DE SÃO PAULO.

Nome da Escola: $E \in$ Plof Zenaide Data: $1+103 / 46$

1. O que é Energia Nuclear? Onde pode ser utilizada?

E'uma energa movida a fricề de URóneo e Tamberm chamada Ailómice. Pode ser ullizada por exom plo pare producen bombar, energia eletrica, etc.

2. SE você fizesse parte da "Equipe Científica Intelectual" do governo, seria a favor da utilização da Energia Nuclear? Em qual área? Justifique a sua resposta.

Náo gostara de parlicipar desta Equipe, por pare a resta saúde.

3. O Brasil tem se beneficiado da Evolução da Tecnologia Nuclear? Como?

Alualmente só pesquiso: Angre I e Angro II.
Em projeto angra III.

4. Vocês conhecem algum Impacto Ambiental causado pela utilização da Tecnologia Nuclear? Cite Exemplos.

Bambos Cí̄micos da 2a Guerso Mundial.

5. Sobre o assunto de Energia Nuclear, você tem dúvidas ou interesse em saber sobre qual item?

$$
\begin{aligned}
& \text { Tenho vários, pas é asunto bem } \\
& \text { Interlasante. }
\end{aligned}
$$


APÊNDICE C - Fotos de duas Interações

Figura 37 - Apresentação para um grupo de professores e alunos da Escola Estadual Ermano Marchetti, quando se constatou a necessidade de haver uma atividade para melhorar $o$ aprendizado.

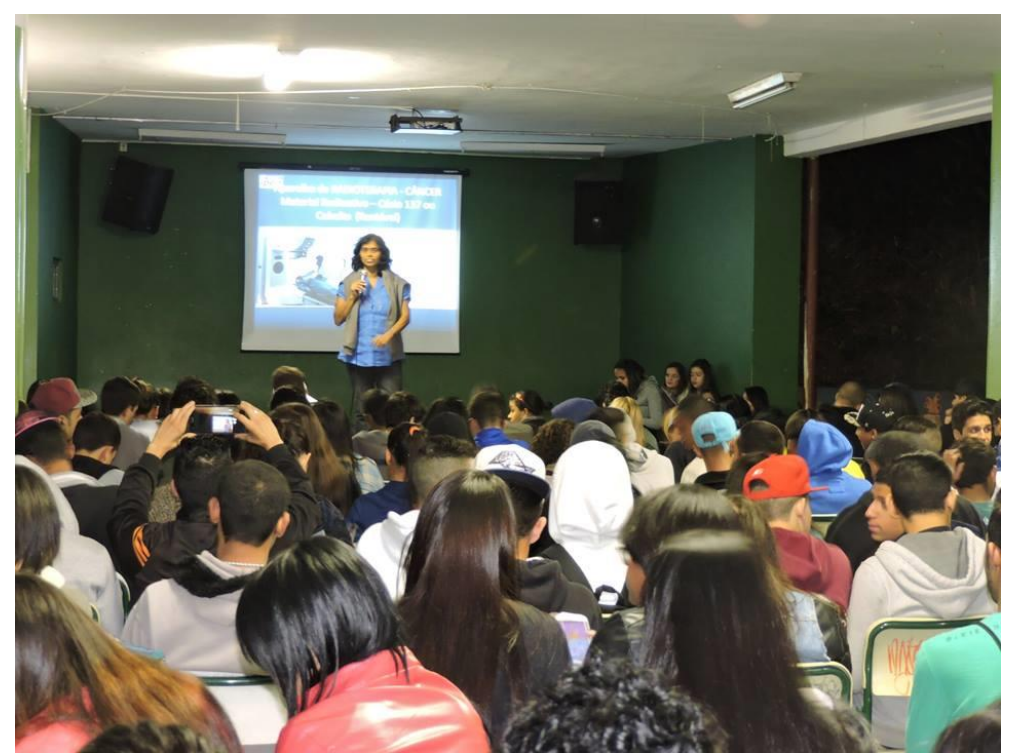

Fonte: Elaborada por Gabriella Bugni

Figura 38 - Apresentação da versão final para professores doutorandos e mestrandos da Escola de Comunicação e Artes da Universidade de São Paulo.

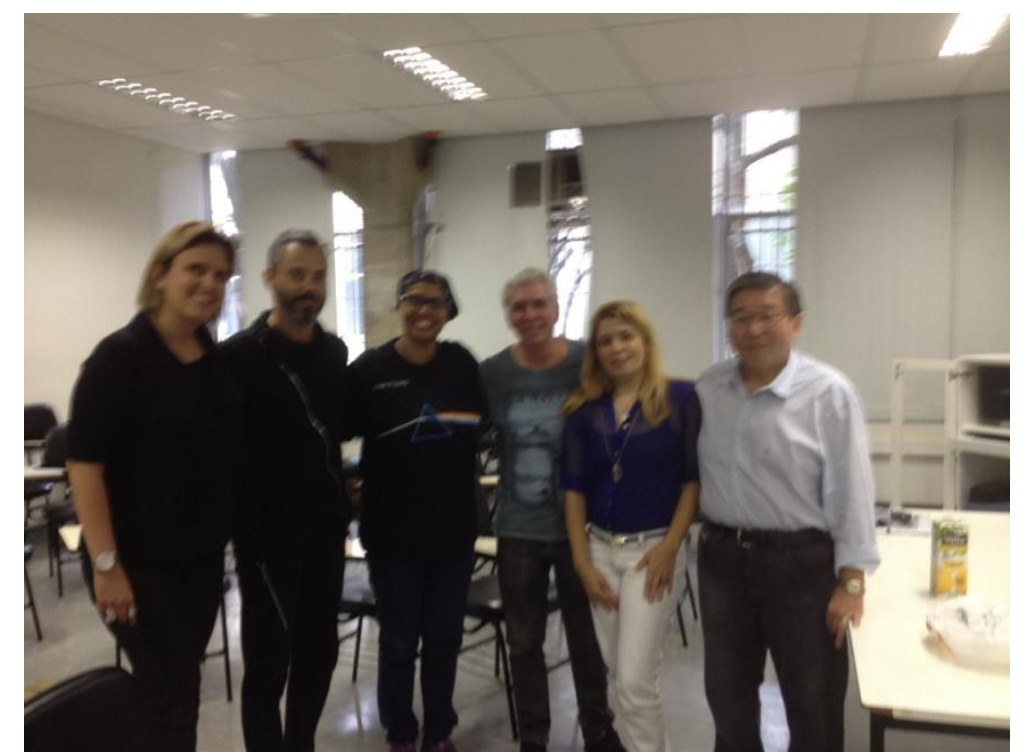

Fonte: Elaborada pela autora. 